This document was prepared in conjunction with work accomplished under Contract No. DE-AC09-96SR18500 with the U. S. Department of Energy.

\title{
DISCLAIMER
}

This report was prepared as an account of work sponsored by an agency of the United States Government. Neither the United States Government nor any agency thereof, nor any of their employees, nor any of their contractors, subcontractors or their employees, makes any warranty, express or implied, or assumes any legal liability or responsibility for the accuracy, completeness, or any third party's use or the results of such use of any information, apparatus, product, or process disclosed, or represents that its use would not infringe privately owned rights. Reference herein to any specific commercial product, process, or service by trade name, trademark, manufacturer, or otherwise, does not necessarily constitute or imply its endorsement, recommendation, or favoring by the United States Government or any agency thereof or its contractors or subcontractors. The views and opinions of authors expressed herein do not necessarily state or reflect those of the United States Government or any agency thereof. 


\section{THE IMPACT OF THE ACTINIDE REMOVAL PROCESS (ARP) ON THE SB4 PROJECTED OPERATING WINDOWS}

D.K. Peeler

T.B. Edwards

March 2005

Immobilization Technology Section Savannah River National Laboratory Aiken, SC 29808

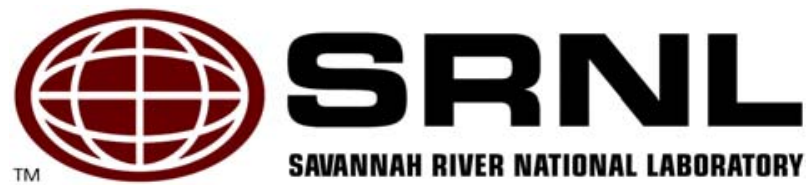


WSRC-TR-2005-00123

Revision 0

\title{
DISCLAIMER
}

This report was prepared by Westinghouse Savannah River Company (WSRC) for the United States Department of Energy under Contract No. DE-AC09-96SR18500 and is an account of work performed under that contract. Neither the United States Department of Energy, nor WSRC, nor any of their employees makes any warranty, expressed or implied, or assumes any legal liability or responsibility for the accuracy, completeness, or usefulness, of any information, apparatus, or product or process disclosed herein or represents that its use will not infringe privately owned rights. Reference herein to any specific commercial product, process, or service by trademark, name, manufacturer or otherwise does not necessarily constitute or imply endorsement, recommendation, or favoring of same by WSRC or by the United States Government or any agency thereof. The views and opinions of the authors expressed herein do not necessarily state or reflect those of the United States Government or any agency thereof.

\author{
Printed in the United States of America \\ Prepared For \\ U.S. Department of Energy
}


Key Words: DWPF, projected operating windows, sulfate

Retention: Permanent

\section{THE IMAPCT OF THE ACTINIDE REMOVAL PROCESS (ARP) ON THE SB4 PROJECTED OPERATING WINDOWS}

D.K. Peeler

T.B. Edwards

March 2005

Immobilization Technology Section Savannah River National Laboratory Aiken, SC 29808

Prepared for the U.S. Department of Energy Under Contract Number DEAC09-96SR18500
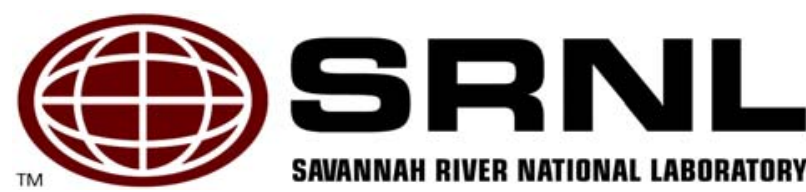

SAUANNAH RIVER NATIONAL LABORATORY 


\section{REVIEWS AND APPROVALS}

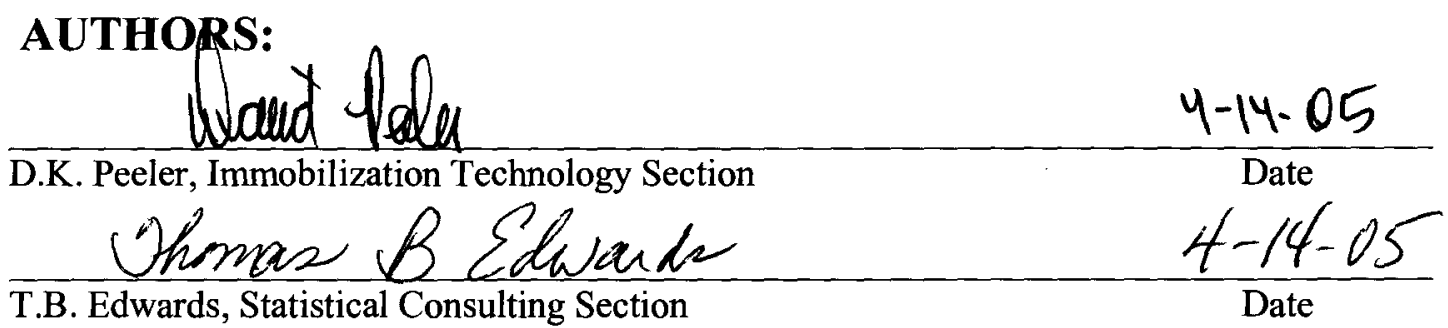

\section{TECHNICAL REVIEWER:}

$\frac{\text { Onmi C. Dhmaner }}{\text { C.C. Herman, Immobilization Technology Section }} \frac{4-18-05}{\text { Date }}$

\section{APPROVERS:}

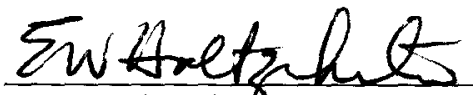

E.W. Holtzscheiter, Manager, Immobilization Technology Section

sorhama

S.L. Marra, Manager, Glass Formulation \& Process Development
$4-14-05$

Date

$4 / 14 / 05$

Date

$4-14-05$

Date 
WSRC-TR-2005-00123

Revision 0

\section{EXECUTIVE SUMMARY}

The model-based assessments of nominal Sludge Batch 4 (SB4) compositions suggest that a viable frit candidate does not appear to be a limiting factor as the Closure Business Unit (CBU) considers various tank blending options for SB4 with or without the Actinide Removal Process (ARP) streams. This statement is based solely on the projected operating windows derived from model predictions and does not include experimental assessments of $\mathrm{SO}_{4}$ solubility or melt rate issues.

To assess the impact of the various ARP options on the projected operating windows, the 1100 canister SB4 baseline options served as the technical baseline or reference point for the comparisons. With respect to the various ARP options being considered, the impacts to the projected operating windows were relatively consistent with the impacts being dependent upon the property limiting access to higher WLs. More specifically, for those 1100 canister SB4 systems (without ARP) which were $T_{L}$-limited, the general impact was an increase in the upper WL which was classified as acceptable resulting in an overall increase in the operating window size. The anticipated negative impact of $\mathrm{TiO}_{2}$ (due to an assumed increase in $\mathrm{T}_{\mathrm{L}}$ which would further reduce the size of the operating window of such systems) was not observed. The hypothesis is that the negative impact was countered or compensated by a positive impact due to the additional $\mathrm{Na}_{2} \mathrm{O}$ from the ARP process. The overall result was a net increase in the size of the operating window for the SB4 1100 canister options which were $\mathrm{T}_{\mathrm{L}}$-limited. This trend was observed for all five ARP options with the only difference being the magnitude of the increase (ranging from a 1\% - 4\% increase) which was strictly based on the specific ARP composition and blending strategy.

Another general observation for all five ARP options was a negative impact with their addition to a 1100 canister system that was initially low viscosity limited or durability limited. For these systems, addition of each ARP stream resulted in a negative impact to the upper WL defining the operating window as a result of the additional $\mathrm{Na}_{2} \mathrm{O}$ introduced which drove both viscosity and durability predictions lower at the same WL. The magnitude of the impact ranged from a $1-2 \%$ reduction for low viscosity limited systems to complete elimination of the operating windows for durability limited systems. The latter situation (i.e., complete elimination of the operating window for a given SB4 blending option with a specified frit) would require a change in frit to compositionally compensate for the ARP addition.

One of the most interesting ARP options was the introduction of the ARP-K case. Model-based predictions and projected $\mathrm{TiO}_{2}$ concentrations, would require an increase in the current $\mathrm{PCCS} \mathrm{TiO} 2$ limit from $1 \mathrm{wt} \%$ to $2 \mathrm{wt} \%$ (if WLs targeting 39\% or greater are desired). With this increase, there appears to be some potential advantages of this ARP stream relative to the other four ARP options. One potential advantage is based on the $\sim 4 \%$ increase in the upper WL defining the projected window for most of the options being considered (which were initially $\mathrm{T}_{\mathrm{L}}$ limited). Although potentially advantageous for some systems, the addition of the ARP-K stream could be devastating to other systems if compositional adjustments are not made (i.e., a frit change). Frits could be selected that are robust to the inclusion of the ARP but they may not be optimized for other properties (e.g., melt rate).

Although ARP-K has potential advantages on the projected operating windows, the other ARP options evaluated should not be dismissed as other criteria (e.g., melt rate and/or CPC processing issues) should be considered prior to pursuing a particular ARP processing scenario. More specifically, based on the assessments performed in this report, there are no show-stoppers for any of the ARP options being considered - although some options could require a frit change between a "sludge-only" flowsheet and its "coupled" (sludge plus ARP) counterpart. 
Based on the SB4 - ARP blending strategies, the additions of $\mathrm{TiO}_{2}$ and $\mathrm{SO}_{4}$ from the ARP streams could result in these oxides exceeding some critical value that would give rise to uncertainties or questions associated with the applicability of select models or exceeding individual solubility limits. In general, establishing a PCCS $\mathrm{SO}_{4}$ limit of 0.5 or $0.6 \mathrm{wt} \%$ (in glass) appears to be sufficient to avoid the SB4 - ARP systems from being $\mathrm{SO}_{4}$ limited at the upper WLs. With respect to model applicability issues, the primary PCCS model of concern was the $\mathrm{T}_{\mathrm{L}}$ model which was developed over $\mathrm{TiO}_{2}$ concentrations ranging from $0.0-1.8549 \mathrm{wt} \%$ (in glass). Although the ARP- $\mathrm{K}$ option would require the $\mathrm{TiO}_{2}$ limit to be raised to $2.0 \mathrm{wt} \%$, maximum $\mathrm{TiO}_{2}$ concentrations in glass are well below the $2 \mathrm{wt} \%$ limit established by Lorier and Jantzen (2003). 


\section{TABLE OF CONTENTS}

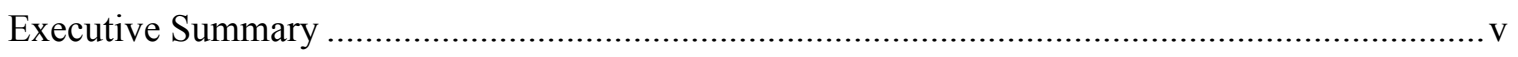

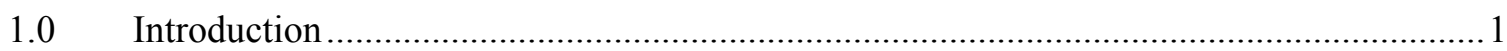

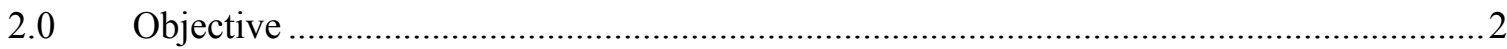

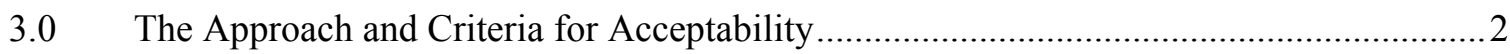

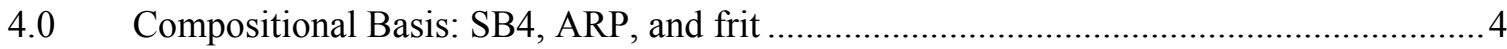

5.0 Projected Operating Windows for the 20 SB4 Blending Options without ARP ...............6

6.0 Projected Operating Windows for the 1100 Canister Baseline with ARP ........................ 9

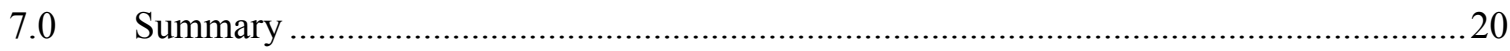

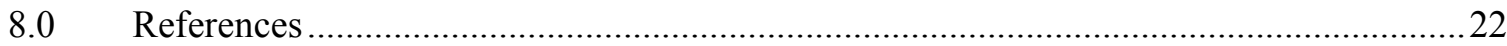

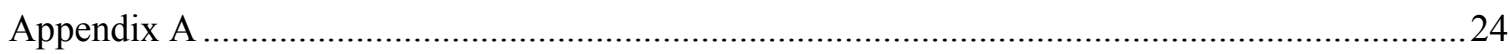

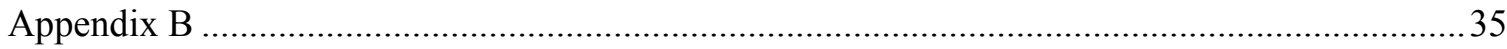

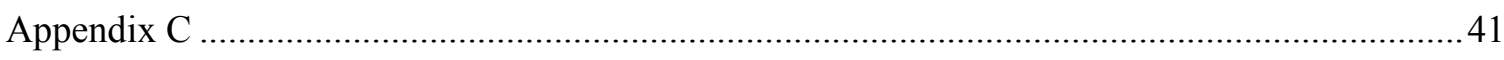




\section{LIST OF TABLES}

Table 4-1. General Description of the Five ARP Cases..................................................................................

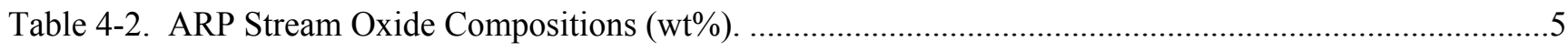

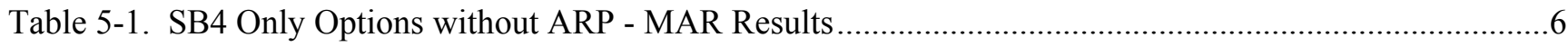

Table 5-2. 1100 Canister Options without ARP - MAR Results ....................................................................

Table 5-3. 1200 Canister Options without ARP - MAR Results ..............................................................

Table 6-1. MAR Results for the SB4 1100 Canister + ARP-A Cases ...........................................................10

Table 6-2. MAR Results for the SB4 1100 Canister + ARP-E Cases ...........................................................13

Table 6-3. MAR Results for the SB4 1100 Canister + ARP-K Cases ...........................................................14

Table 6-4. MAR Results for the SB4 1100 Canister + ARP-K Cases .............................................................15

Table 6-5. MAR Results for the SB4 1100 Canister + ARP-M Cases.............................................................16

Table 6-6. MAR Results for the SB4 1100 Canister + ARP-V Cases ..........................................................17

Table 6-7. MAR Results for the SB4 1100 Canister + ARP-V for the "Max Al" and "Max Ti" Blending

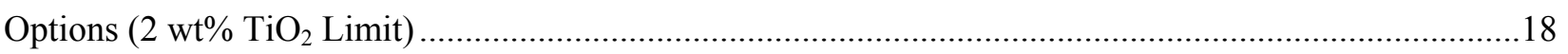

Table 6-8. The Impact of $\mathrm{SO}_{4}$ of the Projected Operating Windows ............................................................19 


\section{LIST OF ACRONYMS}

$\begin{array}{ll}\text { ARP } & \text { Actinide Removal Process } \\ \text { ASTM } & \text { American Society for Testing and Materials } \\ \text { CBU } & \text { Closure Business Unit } \\ \text { CPC } & \text { Chemical Processing Cell } \\ \text { DWPF } & \text { Defense Waste Processing Facility } \\ \Delta G_{P} & \text { preliminary glass dissolution estimator } \\ \text { MAR } & \text { Measurement Acceptability Region } \\ \text { MCU } & \text { Modular Caustic Side Solvent Extraction Unit } \\ \text { MST } & \text { monosodium titanate } \\ \text { NL [B] } & \text { normalized boron release (in g/L) } \\ \text { PCCS } & \text { Product Composition Control System } \\ \text { PCT } & \text { Product Consistency Test } \\ \text { SB } & \text { sludge batch } \\ \text { SRAT } & \text { Sludge Receipt and Adjustment Tank } \\ \text { SRNL } & \text { Savannah River National Laboratory } \\ \text { SRS } & \text { Savannah River Site } \\ T_{L} & \text { liquidus temperature } \\ \eta & \text { viscosity } \\ \text { WL } & \text { waste loading } \\ \text { WSRC } & \text { Westinghouse Savannah River Company }\end{array}$


WSRC-TR-2005-00123

Revision 0

\subsection{INTRODUCTION}

The Defense Waste Processing Facility (DWPF) is currently processing Sludge Batch 3 (SB3) as a "sludgeonly" composition by combining SB3 with Frit 418, melting the slurry mix of sludge and frit, and pouring the molten glass in stainless steel canisters to create the final waste form for this high-level waste at the Savannah River Site (SRS). In preparation for the qualification and receipt of the next sludge batch, Sludge Batch 4 (SB4), development and definition of the baseline flowsheet have been initiated (Lilliston 2005). Various tank blending strategies are being contemplated for SB4 in an effort to meet critical Closure Business Unit (CBU) objectives including issues associated with the durability of the DWPF glass waste form and the efficiency and effectiveness of the DWPF operation. SB4, as currently projected, will be a blend of Tanks 4, 5, 6, 11, and heels from Tanks 7 and 8. In addition, excess Pu and $\mathrm{Np}$ streams from canyon disposition and streams from the Actinide Removal Process (ARP) and the Modular Caustic Side Solvent Extraction Unit (MCU) may also be added during the processing of SB4.

Critical components of DWPF's operational efficiency and effectiveness include sludge/frit processability, melter attainment (the percentage of time DWPF's melter is pouring), melt rate, waste loading, and canister production rates. An early yet meaningful assessment of the processability of a sludge option and of the durability of the final waste form for candidate frits at various waste loadings is provided by using predictions generated by property/composition models. Peeler and Edwards (2005) have identified various frit compositions that provide attractive operating windows (defined in terms of an upper and lower waste loading (WL) in which all glass properties meet DWPF acceptability requirements) based on model assessments. Those assessments were specifically focused on the 20 options provided by Lilliston (2005) that accounted for the uncertainty in sludge volumes remaining in each tank, the possibility that not all of the tanks will be included in SB4, and two different blend points with the heel of SB3. The assessments did not include or address the potential impacts of ARP, MCU, and/or Pu streams that could be blended with SB4.

The impact (or lack thereof) of the MCU stream on the need for a variability study has been addressed in a separate memo (Peeler et al. 2005). Conclusions from that study indicated that although direct applicability of the durability $\left(\Delta \mathrm{G}_{\mathrm{P}}\right)$ model can not be demonstrated to the specific SB4 flowsheet (given the premature nature of the inputs needed to define the glass composition region of interest), one can conclude with high confidence that the incorporation of the MCU stream in the final SB4 flowsheet (regardless of its composition) will have no impact on the decision to perform a variability study. That is, the minimal compositional changes to the SB4 flowsheet from MCU incorporation are practically insignificant and will not influence the decision to perform a variability study for SB4. One can take that conclusion a step further to state that the compositional impacts of MCU will not govern or have any practical impact on the need to reformulate a frit to retain or regain model-based projected operating windows.

Therefore, the primary focus of this report is on the potential impacts of ARP on frit development efforts. That is, could the compositional changes resulting from the assumed ARP blending strategies be sufficient enough to warrant a change in the frit selection process for SB4? The technical baseline that Peeler and Edwards (2005) established for SB4 (without ARP) will serve as the reference point for such comparisons. In addition to monitoring the impact of ARP on the projected operating windows, identification of "troublesome" components introduced through the ARP process which may ultimately influence the projected windows and/or cause concern of either model applicability or individual solubility issues will be of utmost concern.

The Savannah River National Laboratory (SRNL) has been asked via a technical task request (Washburn 2004) to provide frit development support for SB4. In response, SRNL has issued a task technical and 
quality assurance plan (Peeler 2004), and it is under the auspices of that plan that this report has been prepared.

Objectives for this task are specified in Section 2.0. In Section 3.0, a brief review of the strategy or approach for developing and assessing new or existing frits is provided as well as the criteria used to make acceptability decisions. Projected SB4 nominal compositions are summarized in Section 4.0 from which the model-based assessments will be founded. Section 5.0 summarizes the Nominal Stage, Measurement Acceptability Region (MAR) based assessments for the 20 SB4 blending scenarios without ARP which serve as a baseline for comparing the impacts of the ARP streams. Section 6.0 summarizes the projected operating windows for the nominal SB4 cases with ARP and discusses the general trends observed. Section 7.0 provides a summary of these assessments.

\subsection{OBJECTIVE}

The objective of this task is to assess the impact of various ARP processing alternatives on the SB4 projected operating windows. This information will be provided to the CBU and will identify the potential need for augmenting the frit selection process to accommodate inclusion of the ARP stream into SB4. In addition, model applicability and/or individual solubility limit issues will be monitored for select oxides introduced by the ARP streams or that when combined with the projected SB4 compositions exceed some critical value. The information provided in this report is solely focused on model-based projections of the Product Composition Control System (PCCS) operational windows for various SB4 blending strategies of interest. Experimental assessments of melt rate or $\mathrm{SO}_{4}$ solubility are not addressed in this report but are being addressed in parallel tasks. Although not included in the scope of this report, such experimental work is planned as part of the support for SB4 (Peeler and Smith 2004 and Peeler 2004) since these are critical inputs to the final selection of a frit for SB4.

\subsection{THE APPROACH AND CRITERIA FOR ACCEPTABILITY}

To meet the programmatic objectives, the Nominal Stage assessments as proposed by Peeler and Edwards (2002) were used to assess various frit/sludge combinations. The assessment utilized nominal SB4 compositions representing potential tank blending scenarios as outlined by Lilliston (2005). In general, this stage assessed candidate frit compositions with respect to their ability to provide a relatively large projected operating window based solely on a specific nominal composition - no sludge variation was accounted for in this phase. Assessments were made using predictions from models currently implemented in DWPF's PCCS over the waste loading (WL) interval of interest $(25-60 \mathrm{wt} \%)$. The primary property predictions assessed included those for liquidus temperature $\left(\mathrm{T}_{\mathrm{L}}\right)$, viscosity $(\eta)$, and durability (normalized boron release - NL[B] as defined by the Product Consistency Test (PCT) [ASTM 2002]).

It is recognized that the Nominal Stage assessments do not account for anticipated compositional variation. However, the compositional projections provided by Lilliston (2005) were based on various percentages of possible tanks that could represent or be included in SB4. Therefore, the compositions do represent or provide a measure of sludge variation that provides some insight into the robustness of candidate frits with respect to compositional variation. If needed, and as the SB4 flowsheet becomes more mature (primary blending options are further defined), a formal Variation Stage assessment could be performed to address this issue. 
As previously mentioned, the property predictions assessed in this study included durability (as defined by the PCT response in terms of the preliminary glass dissolution estimator $\left(\Delta \mathrm{G}_{\mathrm{P}}\right)$ (Jantzen et al. 1995)), viscosity at $1150^{\circ} \mathrm{C}\left(\eta_{1150^{\circ}} \mathrm{C}\right), \mathrm{T}_{\mathrm{L}}$, and $\mathrm{Al}_{2} \mathrm{O}_{3}$ and alkali concentrations. Jantzen et al. (1995) and Brown et al. (2001) provide a more detailed discussion on the development of these models. To determine projected operational windows for sludge/frit scenarios of interest, the predicted properties must be assessed relative to established acceptance criteria. Acceptable predicted properties for this assessment were based on satisfying their respective MAR limit values. Brown, Postles, and Edwards (2002) provide a detailed discussion of how the MAR limits are utilized in PCCS.

Addition of the various ARP streams does cause some concern regarding the introduction of $\mathrm{TiO}_{2}$ into the system at concentrations that either exceed the current $\mathrm{PCCS} \mathrm{TiO}_{2}$ limit of $1 \mathrm{wt} \%$ (in glass) and/or challenge the range over which the current $\mathrm{T}_{\mathrm{L}}$ model is applicable. Brown et al. (2001) indicated that the current $\mathrm{T}_{\mathrm{L}}$ model was developed over a $\mathrm{TiO}_{2}$ range from 0.0 to $1.8549 \mathrm{wt} \%$ (in glass). Lorier and Jantzen (2003) used this range to establish a technical basis for increasing the current $\mathrm{TiO}_{2}$ limit from $1 \mathrm{wt} \%$ to $2 \mathrm{wt} \%$ (if required). ${ }^{1}$ Although the $2 \mathrm{wt} \%$ limit is available for implementation, the initial model based assessments to be performed will utilize the $1 \mathrm{wt} \%$ constraint. Use of this "conservative" lower limit will flag the need for raising the limit for the various ARP options. That is, there may be blending strategies that would not require the limit to be increased while other options may require the $2 \mathrm{wt} \%$ limit to be utilized. Use of the 1 $\mathrm{wt} \%$ limit will expeditiously identify these cases. If the $1 \mathrm{wt} \%$ limit is found to be restrictive (in terms of the projected operating windows), the restricted option (or set of options) will be "re-evaluated" using the 2 wt $\%$ limit.

Although the $\mathrm{PCCS} \mathrm{SO}_{4}$ limit for SB4 has not been established, various $\mathrm{SO}_{4}$ limits can be used (e.g., 0.4, 0.5 , and $0.6 \mathrm{wt} \%$ in glass) to assess if $\mathrm{SO}_{4}$ will have a negative impact on the projected operating window. For this assessment, the $\mathrm{SO}_{4}$ concentrations in glass will be calculated, but an assumed $\mathrm{SO}_{4}$ limit will not be used to restrict the projected operating windows based on the model predictions. Given there is no MAR uncertainty associated with the $\mathrm{SO}_{4}$ concentration, the maximum WL for each SB4 option can be determined as a function of an assumed $\mathrm{SO}_{4}$ solubility limit based strictly on mathematics (i.e., the assumed $\mathrm{SO}_{4}$ solubility limit divided by the $\mathrm{SO}_{4}$ concentration in sludge times 100 ). For example, if the $\mathrm{SO}_{4}$ concentration in sludge was $1.09 \mathrm{wt} \%$ and the assumed $\mathrm{SO}_{4}$ solubility limit was $0.4 \mathrm{wt} \%$ (in glass), then the maximum WL achievable (based strictly on the $\mathrm{SO}_{4}$ solubility limit) would be $\sim 36.7 \mathrm{wt} \%$. If the $\mathrm{SO}_{4}$ solubility limit was $0.5 \mathrm{wt} \%$, then the maximum achievable WL ((based strictly on the $\mathrm{SO}_{4}$ solubility limit) would be $45.9 \%$. Although one can easily calculate the maximum WL for a given $\mathrm{SO}_{4}$ solubility limit, properties other than $\mathrm{SO}_{4}$ solubility may restrict access to higher WLs. Therefore, a nominal $\mathrm{SO}_{4}$ value $(1.09 \mathrm{wt} \%)$ has been added to each of the 20 options but a $\mathrm{SO}_{4}$ solubility limit in PCCS was not activated with respect to limiting or imposing restrictions on the MAR based assessments for the initial assessments. ${ }^{2}$

\footnotetext{
${ }^{1}$ Lorier and Jantzen (2003) indicate that the substitution of the $\mathrm{T}_{\mathrm{L}}$ model for an absolute solubility limit is based on the fact that not all of the literature glasses surveyed for this study with $\mathrm{TiO}_{2}$ levels $<2 \mathrm{wt} \%$ satisfy the currently implemented $\mathrm{T}_{\mathrm{L}}$ constraint. Since the impact of the $\mathrm{TiO}_{2}$ content of a glass on the $\mathrm{T}_{\mathrm{L}}$ is not linear (i.e., there are interactive effects from other components such as $\mathrm{Cr}_{2} \mathrm{O}_{3}, \mathrm{Fe}_{2} \mathrm{O}_{3}$ and $\mathrm{MnO}$ ), the use of the $\mathrm{T}_{\mathrm{L}}$ model up to a $\mathrm{TiO}_{2}$ solubility limit of $2 \mathrm{wt} \%$ is the only validated approach that can be used for processing in the DWPF.

${ }^{2}$ Shah et.al. (2004) provided the nominal supernate composition for SB4, which included sulfate. For this study, all of the sulfate was assumed to be soluble and the sulfate in the calcined solids was estimated to be $1.09 \mathrm{wt} \%$ assuming a calcine factor similar to that seen for SB4 simulant flowsheet testing.
} 
WSRC-TR-2005-00123

Revision 0

\subsection{COMPOSITIONAL BASIS: SB4, ARP, AND FRIT}

Three primary inputs are required to support the assessment of the impacts of ARP on the SB4 projected operating windows. The primary inputs are: sludge (or waste stream), ARP, and frit compositions as well as blending strategies. Given the focus of this study is to assess the impact of ARP on the projected operating windows, the SB4 and primary frit compositions used by Peeler and Edwards (2005) will serve as the technical baseline. Therefore, the only required input is to define the ARP compositions and assumed blending or processing strategies.

Herman (2005) provides a detailed summary of the preliminary ARP compositions and an overview of the processing strategy. Given both are still being defined, some uncertainty exists with regards to the composition and volume of the stream that will be transferred to DWPF. The ARP stream to be transferred to DWPF will contain monosodium titanate (MST), entrained sludge, and various soluble sodium compounds as the result of filter cleaning and stream composition adjustment for transfer. Herman (2005) reviewed the various material balances for several different processing scenarios provided by Subosits (2004). Twenty-four ARP processing scenarios were reviewed, and five were selected to bound the range of possible components (with potential impacts on the glass formulation) that could be transferred to DWPF. The assumption being that if glass formulation efforts can accommodate the bounding components, then concentrations of the ARP components within the bounds should also be acceptable. Table 4-1 provides a general description of the supporting facilities, feed compositions, nominal flow rates, and selection basis for each option. The five ARP options selected were identified as ARP-A, -E, -K, -M, and $-\mathrm{V}$ and the nominal composition of each (calcined, oxide basis) is listed in Table 4-2. ${ }^{3}$

Table 4-1. General Description of the Five ARP Cases.

\begin{tabular}{|c|c|c|c|c|c|}
\hline Case & ARP-A & ARP-E & ARP-K & ARP-M & ARP-V \\
\hline Facility(ies) & 512-S Only & $\begin{array}{l}\text { 241-96H with } \\
512-S \text { ARP }\end{array}$ & $\begin{array}{c}\text { 241-96H with } \\
512-S \text { ARP }\end{array}$ & 512-S Only & $\begin{array}{l}\text { 241-96H with } \\
\text { 512-S ARP }\end{array}$ \\
\hline Alpha Reactors & Single & Dual & Dual & Single & Dual \\
\hline Feed Composition & Average & $\begin{array}{c}\text { Worst } \\
\text { Inhalation Dose }\end{array}$ & Average & Average & Average \\
\hline $\begin{array}{l}\text { MST Strike Time } \\
\text { (hr) }\end{array}$ & 24 & 24 & 8 & N/A & 8 \\
\hline Filter Size $(\mu \mathrm{m})$ & 0.5 Mott & 0.5 Mott & 0.1 & 0.1 & 0.5 Mott \\
\hline Filter Flux $\left(\mathrm{gpm} / \mathrm{ft}^{2}\right)$ & 0.02 & 0.02 & 0.02 & 0.02 & 0.036 \\
\hline $\begin{array}{l}\text { Nominal Flow rates } \\
(\mathrm{lb} / \mathrm{hr})\end{array}$ & 28.38 & 102.410 & 152.044 & 89.267 & 111.978 \\
\hline Reason for Selection & $\begin{array}{c}\text { Nominal } \\
\text { Feed } \\
\text { Composition } \\
\text { and Volume } \\
\end{array}$ & $\begin{array}{c}\text { High MST and } \\
\text { Sludge Content } \\
\text { with Large } \\
\text { Stream Volume }\end{array}$ & $\begin{array}{c}\text { Highest } \\
\text { Combined Na, } \\
\text { Sludge, and } \\
\text { MST, Volume }\end{array}$ & $\begin{array}{c}\text { Filter Only } \\
\text { Case with No } \\
\text { MST }\end{array}$ & $\begin{array}{l}\text { Intermediate } \\
\text { sludge, MST, } \\
\text { and Na level }\end{array}$ \\
\hline
\end{tabular}

\footnotetext{
${ }^{3}$ Herman (2005) identified the five ARP options as Appendices A, E, K, M, and V. These ARP options are referred to as ARP-A, ARPE, ARP-K, ARP-M, and ARP-V, respectively, throughput this report to avoid confusion with the appendices supporting the MAR assessments.
} 
WSRC-TR-2005-00123

Revision 0

Table 4-2. ARP Stream Oxide Compositions (wt \%). ${ }^{4}$

\begin{tabular}{|c|c|c|c|c|c|}
\hline Oxide & ARP-A & ARP-E & ARP-K & ARP-M & ARP-V \\
\hline $\mathrm{Al}_{2} \mathrm{O}_{3}$ & 6.26 & 7.84 & 6.23 & 10.84 & 6.24 \\
\hline $\mathrm{BaO}$ & 0.087 & 0.116 & 0.086 & 0.169 & 0.086 \\
\hline $\mathrm{CaO}$ & 1.009 & 1.347 & 0.994 & 1.950 & 0.996 \\
\hline $\mathrm{Ce}_{2} \mathrm{O}_{3}$ & 0.167 & 0.223 & 0.165 & 0.323 & 0.165 \\
\hline $\mathrm{Cr}_{2} \mathrm{O}_{3}$ & 0.107 & 0.144 & 0.106 & 0.207 & 0.106 \\
\hline $\mathrm{Cs}_{2} \mathrm{O}$ & 0.0010 & 0.0012 & 0.0009 & 0.0018 & 0.0009 \\
\hline $\mathrm{CuO}$ & 0.045 & 0.060 & 0.045 & 0.087 & 0.045 \\
\hline $\mathrm{Fe}_{2} \mathrm{O}_{3}$ & 12.4 & 16.5 & 12.2 & 24.0 & 12.2 \\
\hline $\mathrm{K}_{2} \mathrm{O}$ & 0.117 & 0.137 & 0.117 & 0.201 & 0.117 \\
\hline $\mathrm{La}_{2} \mathrm{O}_{3}$ & 0.068 & 0.091 & 0.067 & 0.132 & 0.067 \\
\hline $\mathrm{MgO}$ & 0.106 & 0.141 & 0.104 & 0.204 & 0.104 \\
\hline $\mathrm{MnO}$ & 4.65 & 6.21 & 4.58 & 8.98 & 4.59 \\
\hline $\mathrm{Na}_{2} \mathrm{O}$ & 39.6 & 38.5 & 40.3 & 38.6 & 40.2 \\
\hline $\mathrm{NiO}$ & 1.39 & 1.85 & 1.37 & 2.68 & 1.37 \\
\hline $\mathrm{PbO}$ & 0.123 & 0.164 & 0.121 & 0.238 & 0.121 \\
\hline $\mathrm{SO}_{4}$ & 2.84 & 3.09 & 2.90 & 3.24 & 2.90 \\
\hline $\mathrm{SiO}_{2}$ & 0.692 & 0.924 & 0.682 & 1.338 & 0.684 \\
\hline $\mathrm{ThO}_{2}$ & 0.0000 & 0.0000 & 0.0000 & 0.0000 & 0.0000 \\
\hline $\mathrm{TiO}_{2}$ & 26.8 & 17.9 & 26.4 & 0.0 & 26.4 \\
\hline $\mathrm{U}_{3} \mathrm{O}_{8}$ & 3.28 & 4.39 & 3.24 & 6.35 & 3.24 \\
\hline $\mathrm{ZnO}$ & 0.076 & 0.101 & 0.075 & 0.147 & 0.076 \\
\hline $\mathrm{ZrO}_{2}$ & 0.205 & 0.274 & 0.203 & 0.397 & 0.203 \\
\hline
\end{tabular}

From a glass formulation perspective, the oxides introduced from the ARP options of particular interest include $\mathrm{TiO}_{2}, \mathrm{SO}_{4}$, and $\mathrm{Na}_{2} \mathrm{O}$. This does not suggest that the other components are not important but only the fact that the concentrations of these major components have a higher probability of influencing the projected operating windows based on model predictions or individual solubility limits. As expected the $\mathrm{TiO}_{2}$ concentrations are relatively high in all ARP options with the exception of ARP-M (which is $0 \%$ ). The ARP-M case represents a scenario where an MST strike is not performed and only filtration is used. The primary concerns for $\mathrm{TiO}_{2}$ are the impacts to $\mathrm{T}_{\mathrm{L}}$ (in general, as $\mathrm{TiO}_{2}$ concentrations increase, $\mathrm{T}_{\mathrm{L}}$ increases) and the applicability of the $\mathrm{T}_{\mathrm{L}}$ model (i.e., the range of $\mathrm{TiO}_{2}$ over which the $\mathrm{T}_{\mathrm{L}}$ model was developed). ${ }^{5}$ Consider a SB4 blending option (without ARP) that is $\mathrm{T}_{\mathrm{L}}$-limited. The additional $\mathrm{TiO}_{2}$ from the ARP stream could reduce the maximum $\mathrm{WL}$ achievable due to an increased $\mathrm{T}_{\mathrm{L}}$ prediction. This statement assumes that the negative impact of $\mathrm{TiO}_{2}$ is not countered by a reduction in $\mathrm{T}_{\mathrm{L}}$ due to another component in the ARP stream (e.g., $\mathrm{Na}_{2} \mathrm{O}$ ). Another troublesome component is $\mathrm{SO}_{4}$, which represents approximately $3.0 \mathrm{wt} \%$ of the solids in all five ARP options (see Table 42). Depending upon the SB4 blending or processing strategy, the additional $\mathrm{SO}_{4}$ from the ARP streams could transition a SB4 system that is $\mathrm{T}_{\mathrm{L}}$ or low viscosity limited (at the upper WL) to one that is $\mathrm{SO}_{4}$ limited. This potential shift or transition obviously depends on the combined $\mathrm{SO}_{4}$ concentration between $\mathrm{SB} 4$ and the ARP as well as the solubility limit established for the specific system. With respect to $\mathrm{Na}_{2} \mathrm{O}$ additions from the ARP, it is anticipated that when comparing a specific SB4 option (e.g., 1100 canister baseline option) with and without ARP, adjustments to the frit composition may be required to counter or compensate for the incoming $\mathrm{Na}_{2} \mathrm{O}$

\footnotetext{
${ }^{4}$ As previously noted, the compositions shown for ARP-A, -E, -K, -M, and -V in this report are consistent with the nomenclature of Appendix A, E, K, M and V as denoted by Herman (2005).

${ }^{5}$ As noted in Section 3.0, the lower and upper $\mathrm{TiO}_{2}$ bounds over which the model was developed were $0.0 \mathrm{wt} \%$ up to $1.8549 \mathrm{wt} \%$.
} 
content - the "sliding $\mathrm{Na}_{2} \mathrm{O}$ scale" concept as described by Peeler and Edwards (2005). The projected impacts of the ARP streams on the projected operating windows ultimately depend on compositional changes to the overall SRAT product which will be governed by the blending or processing strategy (mass of SB4 and mass of ARP to be blended).

To determine the impact of each ARP stream on the DWPF Sludge Receipt and Adjustment Tank (SRAT) product or glass composition, the five projected ARP stream compositions (see Table 4-1) were individually blended with the 20 SB4 options provided by Lilliston (2005). Herman (2005) used the estimated transfer volumes for each ARP option and blended them with a nominal 6,000 gallon SRAT sludge batch. To estimate the sludge oxide mass contribution, the sludge was assumed to have a total/dried solids of $22 \mathrm{wt} \%$, a calcine factor of 0.72 , and a sludge density of $1.18 \mathrm{~kg} / \mathrm{L}$ for all of the SB4 projected compositions. The total oxides were summed and then renormalized to include the ARP contribution. The resulting SB4 + ARP SRAT products are summarized in Appendix A.

\subsection{PROJECTED OPERATING WINDOWS FOR THE 20 SB4 BLENDING OPTIONS WITHOUT ARP}

Peeler and Edwards (2005) provide a detailed assessment of the MAR results for the 20 SB4 options (without $\mathrm{ARP}$ and $\mathrm{Pu}$ additions) provided by the CBU. That assessment serves as a technical baseline from which the impacts (positive or negative) of ARP on the projected operating windows will be based. As previously mentioned, introduction of $\mathrm{TiO}_{2}, \mathrm{SO}_{4}$, and/or $\mathrm{Na}_{2} \mathrm{O}$ from the ARP process will probably have the largest impact on the projected operating windows assuming compositional compensations of the frit are not made.

For completeness, projected operating windows for the MAR based assessments for all 20 options (i.e., SB4Only, 1100 canister, and 1200 canister cases) are summarized in Table 5-1 through Table 5-3, respectively. The projected operating windows in terms of upper and lower WLs that satisfy the MAR constraints for the specific sludge / frit blend as well as the property that limits access to higher WLs are also provided. As previously mentioned, although the $\mathrm{SO}_{4}$ concentration in glass was monitored, the assessments did not impose or activate a $\mathrm{SO}_{4}$ solubility limit and therefore did not restrict or influence the projected operating windows. ${ }^{6}$ Also shown in Table 5-1 through 5-3 is the nominal $\mathrm{Na}_{2} \mathrm{O}$ concentration (in wt $\%$ ) in the frit ranging from $8 \%$ (Frit 418 ) to $13 \%$ (Frit 431).

Table 5-1. SB4 Only Options without ARP - MAR Results

\begin{tabular}{|c|c|c|c|c|c|c|}
\hline & Frit 418 & Frit 426 & Frit 425 & Frit 417 & Frit 320 & Frit 431 \\
\hline $\begin{array}{l}\% \mathrm{Na}_{2} \mathrm{O} \\
\text { (in frit) }\end{array}$ & 8 & 9 & 10 & 11 & 12 & 13 \\
\hline Baseline & $\begin{array}{c}\text { (high } \eta \text { ) } \\
33-36 \\
\left(\mathrm{~T}_{\mathrm{L}}\right)\end{array}$ & $\begin{array}{c}25-37 \\
\left(\mathrm{~T}_{\mathrm{L}}\right)\end{array}$ & $\begin{array}{c}25-38 \\
\left(T_{L}\right)\end{array}$ & $\begin{array}{c}25-39 \\
\left(\mathrm{~T}_{\mathrm{L}}\right)\end{array}$ & $\begin{array}{c}25-40 \\
\left(\mathrm{~T}_{\mathrm{L}}\right)\end{array}$ & $\begin{array}{c}25-40 \\
\left(\mathrm{~T}_{\mathrm{L}}\right)\end{array}$ \\
\hline $\operatorname{Max} \mathrm{Al}$ & - & - & - & - & $25-60$ & $25-60$ \\
\hline Min Al & $\begin{array}{c}(\text { high } \eta) \\
27-32 \\
\left(T_{L}\right)\end{array}$ & $\begin{array}{c}25-33 \\
\left(T_{L}\right)\end{array}$ & $\begin{array}{c}25-34 \\
\left(T_{L}\right)\end{array}$ & $\begin{array}{c}25-35 \\
\left(\mathrm{~T}_{\mathrm{L}}\right)\end{array}$ & $\begin{array}{c}25-35 \\
\left(T_{L}\right)\end{array}$ & $\begin{array}{c}25-36 \\
\left(T_{L}\right)\end{array}$ \\
\hline
\end{tabular}

\footnotetext{
${ }^{6}$ Imposing a 0.5 or $0.6 \mathrm{wt} \% \mathrm{SO}_{4}$ limit in PCCS typically does not limit the projected windows for any of the 20 SB4 blending options being considered. If the $\mathrm{SO}_{4}$ limit were set at $0.4 \mathrm{wt} \%$, upper WLs would be limited to $\sim 36 \%$ based on the projected $\mathrm{SO}_{4}$ concentrations in SB4.
} 
Table 5-2. 1100 Canister Options without ARP - MAR Results

\begin{tabular}{|c|c|c|c|c|c|c|}
\hline & Frit 418 & Frit 426 & Frit 425 & Frit 417 & Frit 320 & Frit 431 \\
\hline $\begin{array}{l}\% \mathrm{Na}_{2} \mathrm{O} \\
\text { (in frit) }\end{array}$ & 8 & 9 & 10 & 11 & 12 & 13 \\
\hline Baseline & $\begin{array}{c}25-42 \\
\left(\mathrm{~T}_{\mathrm{L}}\right)\end{array}$ & $\begin{array}{c}25-43 \\
\left(T_{L}\right)\end{array}$ & $\begin{array}{c}25-44 \\
\left(\mathrm{~T}_{\mathrm{L}}\right)\end{array}$ & $\begin{array}{c}25-45 \\
\left(\mathrm{~T}_{\mathrm{L}}\right)\end{array}$ & $\begin{array}{l}25-44 \\
(\text { low } \eta)\end{array}$ & $\begin{array}{c}\left(\Delta \mathrm{G}_{\mathrm{P}}\right) \\
27-41 \\
(\text { low } \eta)\end{array}$ \\
\hline $\begin{array}{c}2^{\text {nd }} \\
\text { transfer } \\
\text { baseline }\end{array}$ & $\begin{array}{c}25-40 \\
\left(\mathrm{~T}_{\mathrm{L}}\right)\end{array}$ & $\begin{array}{c}25-41 \\
\left(T_{L}\right)\end{array}$ & $\begin{array}{c}25-42 \\
\left(\mathrm{~T}_{\mathrm{L}}\right)\end{array}$ & $\begin{array}{c}25-43 \\
\left(T_{L}\right)\end{array}$ & $\begin{array}{c}25-44 \\
\left(T_{L}\right)\end{array}$ & $\begin{array}{l}25-43 \\
(\text { low } \eta)\end{array}$ \\
\hline Min Al & $\begin{array}{c}25-40 \\
\left(\mathrm{~T}_{\mathrm{L}}\right)\end{array}$ & $\begin{array}{c}25-41 \\
\left(T_{L}\right) \\
\end{array}$ & $\begin{array}{c}25-42 \\
\left(T_{L}\right)\end{array}$ & $\begin{array}{c}25-43 \\
\left(T_{L}\right)\end{array}$ & $\begin{array}{l}25-41 \\
(\text { low } \eta)\end{array}$ & - \\
\hline Max Al & $\begin{array}{c}\text { high } \eta) \\
27-51 \\
\left(T_{L}\right)\end{array}$ & $\begin{array}{c}25-52 \\
\left(\mathrm{~T}_{\mathrm{L}}\right)\end{array}$ & $\begin{array}{c}25-53 \\
\left(\mathrm{~T}_{\mathrm{L}}\right)\end{array}$ & $\begin{array}{c}25-54 \\
\left(T_{L}\right)\end{array}$ & $\begin{array}{l}25-53 \\
(\text { low } \eta)\end{array}$ & $\begin{array}{l}25-50 \\
(\text { low } \eta)\end{array}$ \\
\hline Min $\mathrm{Ce}$ & $\begin{array}{c}25-38 \\
\left(\mathrm{~T}_{\mathrm{L}}\right)\end{array}$ & $\begin{array}{c}25-39 \\
\left(T_{L}\right)\end{array}$ & $\begin{array}{c}25-40 \\
\left(T_{L}\right)\end{array}$ & $\begin{array}{c}25-41 \\
\left(T_{L}\right)\end{array}$ & $\begin{array}{c}25-41 \\
\left(\mathrm{~T}_{\mathrm{L}}\right)\end{array}$ & $\begin{array}{c}25-42 \\
\left(T_{L}\right)\end{array}$ \\
\hline Min Fe & $\begin{array}{c}\text { (high } \eta) \\
26-41 \\
\left(T_{L}\right)\end{array}$ & $\begin{array}{c}25-42 \\
\left(T_{L}\right)\end{array}$ & $\begin{array}{c}25-43 \\
\left(T_{L}\right)\end{array}$ & $\begin{array}{c}25-44 \\
\left(T_{L}\right)\end{array}$ & $\begin{array}{c}25-45 \\
\left(T_{L}\right)\end{array}$ & $\begin{array}{c}25-46 \\
\left(\mathrm{~T}_{\mathrm{L}}\right)\end{array}$ \\
\hline Max Mg & $\begin{array}{c}25-41 \\
\left(\mathrm{~T}_{\mathrm{L}}\right)\end{array}$ & $\begin{array}{c}25-42 \\
\left(T_{L}\right)\end{array}$ & $\begin{array}{c}25-43 \\
\left(T_{L}\right)\end{array}$ & $\begin{array}{c}25-44 \\
\left(T_{L}\right)\end{array}$ & $\begin{array}{l}25-43 \\
(\text { low } \eta)\end{array}$ & $\begin{array}{c}\left(\Delta \mathrm{G}_{\mathrm{P}}\right) \\
32-40 \\
(\text { low } \eta)\end{array}$ \\
\hline Max Ni & $\begin{array}{c}25-36 \\
\left(T_{L}\right)\end{array}$ & $\begin{array}{c}25-37 \\
\left(T_{L}\right)\end{array}$ & $\begin{array}{c}25-38 \\
\left(T_{L}\right)\end{array}$ & $\begin{array}{c}25-39 \\
\left(T_{L}\right)\end{array}$ & $\begin{array}{c}25-40 \\
\left(T_{L}\right)\end{array}$ & $\begin{array}{c}25-41 \\
\left(\mathrm{~T}_{\mathrm{L}} / \text { low } \eta\right)\end{array}$ \\
\hline Max Ti & $\begin{array}{c}25-50 \\
\left(\mathrm{~T}_{\mathrm{L}}\right) \\
\end{array}$ & $\begin{array}{c}25-51 \\
\left(\mathrm{~T}_{\mathrm{L}}\right) \\
\end{array}$ & $\begin{array}{c}25-52 \\
\left(\mathrm{~T}_{\mathrm{L}}\right) \\
\end{array}$ & $\begin{array}{l}25-52 \\
(\text { low } \eta) \\
\end{array}$ & $\begin{array}{l}25-49 \\
(\text { low } \eta)\end{array}$ & $\begin{array}{l}25-46 \\
(\text { low } \eta) \\
\end{array}$ \\
\hline
\end{tabular}


Table 5-3. 1200 Canister Options without ARP - MAR Results

\begin{tabular}{|c|c|c|c|c|c|c|}
\hline & Frit 418 & Frit 426 & Frit 425 & Frit 417 & Frit 320 & Frit 431 \\
\hline $\begin{array}{l}\% \mathrm{Na}_{2} \mathrm{O} \\
\text { (in frit) }\end{array}$ & 8 & 9 & 10 & 11 & 12 & 13 \\
\hline Baseline & $\begin{array}{c}25-41 \\
\left(T_{L}\right) \\
\end{array}$ & $\begin{array}{c}25-42 \\
\left(\mathrm{~T}_{\mathrm{L}}\right) \\
\end{array}$ & $\begin{array}{c}25-43 \\
\left(\mathrm{~T}_{\mathrm{L}}\right) \\
\end{array}$ & $\begin{array}{c}25-44 \\
\left(\mathrm{~T}_{\mathrm{L}}\right) \\
\end{array}$ & $\begin{array}{c}25-45 \\
\left(\mathrm{~T}_{\mathrm{L}} / \text { low } \eta\right)\end{array}$ & $\begin{array}{l}25-42 \\
(\text { low } \eta)\end{array}$ \\
\hline $\begin{array}{c}2^{\text {nd }} \\
\text { transfer } \\
\text { baseline }\end{array}$ & $\begin{array}{c}25-40 \\
\left(\mathrm{~T}_{\mathrm{L}}\right)\end{array}$ & $\begin{array}{c}25-41 \\
\left(\mathrm{~T}_{\mathrm{L}}\right)\end{array}$ & $\begin{array}{c}25-42 \\
\left(\mathrm{~T}_{\mathrm{L}}\right)\end{array}$ & $\begin{array}{c}25-43 \\
\left(\mathrm{~T}_{\mathrm{L}}\right)\end{array}$ & $\begin{array}{c}25-44 \\
\left(\mathrm{~T}_{\mathrm{L}}\right)\end{array}$ & $\begin{array}{l}25-44 \\
\text { (low } \eta)\end{array}$ \\
\hline $\operatorname{Min} \mathrm{Al}$ & $\begin{array}{c}25-39 \\
\left(\mathrm{~T}_{\mathrm{L}}\right)\end{array}$ & $\begin{array}{c}25-40 \\
\left(\mathrm{~T}_{\mathrm{L}}\right)\end{array}$ & $\begin{array}{c}25-40 \\
\left(\mathrm{~T}_{\mathrm{L}}\right)\end{array}$ & $\begin{array}{c}25-41 \\
\left(\mathrm{~T}_{\mathrm{L}}\right)\end{array}$ & $\begin{array}{c}25-42 \\
\left(\mathrm{~T}_{\mathrm{L}} / \text { low } \eta\right)\end{array}$ & $\begin{array}{c}\left(\Delta \mathrm{G}_{\mathrm{P}}\right) \\
35-39 \\
(\text { low } \eta)\end{array}$ \\
\hline Max Al & $\begin{array}{c}(\text { high } \eta) \\
29-53 \\
\left(T_{L}\right)\end{array}$ & $\begin{array}{c}25-54 \\
\left(\mathrm{~T}_{\mathrm{L}}\right)\end{array}$ & $\begin{array}{c}25-54 \\
\left(\mathrm{~T}_{\mathrm{L}}\right)\end{array}$ & $\begin{array}{c}25-55 \\
\left(\mathrm{~T}_{\mathrm{L}}\right)\end{array}$ & $\begin{array}{c}25-56 \\
\left(T_{L} / \text { low } \eta\right)\end{array}$ & $\begin{array}{l}25-53 \\
(\text { low } \eta)\end{array}$ \\
\hline Max Ni & $\begin{array}{c}25-36 \\
\left(\mathrm{~T}_{\mathrm{L}}\right)\end{array}$ & $\begin{array}{c}25-37 \\
\left(\mathrm{~T}_{\mathrm{L}}\right)\end{array}$ & $\begin{array}{c}25-38 \\
\left(\mathrm{~T}_{\mathrm{L}}\right)\end{array}$ & $\begin{array}{c}25-39 \\
\left(\mathrm{~T}_{\mathrm{L}}\right) \\
\end{array}$ & $\begin{array}{c}25-40 \\
\left(\mathrm{~T}_{\mathrm{L}}\right) \\
\end{array}$ & $\begin{array}{c}25-41 \\
\left(\mathrm{~T}_{\mathrm{L}} / \text { low } \eta\right)\end{array}$ \\
\hline Min Ce & $\begin{array}{c}(\text { high } \eta) \\
26-41 \\
\left(T_{L}\right)\end{array}$ & $\begin{array}{c}25-42 \\
\left(T_{L}\right)\end{array}$ & $\begin{array}{c}25-43 \\
\left(\mathrm{~T}_{\mathrm{L}}\right)\end{array}$ & $\begin{array}{c}25-44 \\
\left(T_{L}\right)\end{array}$ & $\begin{array}{c}25-45 \\
\left(\mathrm{~T}_{\mathrm{L}}\right)\end{array}$ & $\begin{array}{c}25-46 \\
\left(\mathrm{~T}_{\mathrm{L}}\right)\end{array}$ \\
\hline Min $\mathrm{Mg}$ & $\begin{array}{c}25-38 \\
\left(\mathrm{~T}_{\mathrm{L}}\right)\end{array}$ & $\begin{array}{c}25-39 \\
\left(\mathrm{~T}_{\mathrm{L}}\right) \\
\end{array}$ & $\begin{array}{c}25-40 \\
\left(\mathrm{~T}_{\mathrm{L}}\right) \\
\end{array}$ & $\begin{array}{c}25-41 \\
\left(\mathrm{~T}_{\mathrm{L}}\right) \\
\end{array}$ & $\begin{array}{c}25-42 \\
\left(\mathrm{~T}_{\mathrm{L}}\right) \\
\end{array}$ & $\begin{array}{c}25-42 \\
\left(\mathrm{~T}_{\mathrm{L}}\right) \\
\end{array}$ \\
\hline Max Mg & $\begin{array}{c}\text { (high } \eta) \\
26-51 \\
\left(T_{L}\right) \\
\end{array}$ & $\begin{array}{c}25-52 \\
\left(\mathrm{~T}_{\mathrm{L}}\right)\end{array}$ & $\begin{array}{c}25-53 \\
\left(\mathrm{~T}_{\mathrm{L}}\right)\end{array}$ & $\begin{array}{c}25-54 \\
\left(\mathrm{~T}_{\mathrm{L}} / \text { low } \eta\right)\end{array}$ & $\begin{array}{l}25-51 \\
(\text { low } \eta)\end{array}$ & $\begin{array}{l}25-48 \\
(\text { low } \eta)\end{array}$ \\
\hline
\end{tabular}


WSRC-TR-2005-00123

Revision 0

\subsection{PROJECTED OPERATING WINDOWS FOR THE 1100 CANISTER BASELINE WITH ARP}

Given there are 20 nominal SB4 cases, 5 ARP options (referred to as ARP-A, -E, -K, -M, and -V), and 6 different candidate frits, a total of 600 glass systems can be developed. Within each glass system, 36 individual WLs exist which results in 21,600 specific glasses to be assessed against the MAR. Obviously, the number of comparisons one can make among the various systems is extremely large and exceeds the number of comparisons that will be made in this report. In addition, predictions of various properties at each WL within a specific system become too numerous to list and if listed, could be of limited use. Therefore, in this report, an example of the impact of the various ARP streams on the projected operating windows will be provided to demonstrate various concepts that can then be used to make specific comparisons of interest to the individual reader. The SB4 blending option of choice will be the 1100 canister baseline case given its current classification as the "baseline" flowsheet. Details regarding each of the 600 glass systems are provided in Appendix B so the reader can make specific comparisons as warranted. In addition to the specific discussions for the 1100 canister baseline option, some high-level, general statements will be summarized for each of the 5 ARP options. For example, if a particular ARP option results in complete elimination of an operating window that option will be highlighted. The projected operating windows for the various SB4 1100 canister - ARP processing options are provided in Tables 6-1 through Table 6-6.

\subsection{ARP-A}

Table 6-1 summarizes the projected operating windows for the SB4 + ARP-A cases. Although discussions or comparisons with these options relative to the SB4 with no ARP cases may be considered extensive, this does not suggest that this option is more advantageous relative to another ARP option. The more detailed discussions are provided to established "similar" effects of the ARP streams which will only be highlighted in subsequent discussions. The primary focus of later systems will be to highlight differences among the ARP options that may provide distinguishing beneficial impacts that could be used to down select or target on one or more ARP options, if warranted.

\footnotetext{
${ }^{7}$ Detailed property predictions for each glass system can be found in WSRC-NB-2004-00134.
} 
WSRC-TR-2005-00123

Revision 0

Table 6-1. MAR Results for the SB4 1100 Canister + ARP-A Cases

\begin{tabular}{|c|c|c|c|c|c|c|}
\hline & Frit 418 & Frit 426 & Frit 425 & Frit 417 & Frit 320 & Frit 431 \\
\hline $\begin{array}{l}\% \mathrm{Na}_{2} \mathrm{O} \\
\text { (in frit) }\end{array}$ & 8 & 9 & 10 & 11 & 12 & 13 \\
\hline Baseline & $\begin{array}{c}25-42 \\
\left(\mathrm{~T}_{\mathrm{L}}\right)\end{array}$ & $\begin{array}{c}25-43 \\
\left(\mathrm{~T}_{\mathrm{L}}\right)\end{array}$ & $\begin{array}{c}25-44 \\
\left(T_{L}\right)\end{array}$ & $\begin{array}{c}25-45 \\
\left(T_{L}\right)\end{array}$ & $\begin{array}{l}25-43 \\
\text { (low } \eta)\end{array}$ & $\begin{array}{c}\left(\Delta \mathrm{G}_{\mathrm{P}}\right) \\
31-40 \\
(\text { low } \eta)\end{array}$ \\
\hline $\begin{array}{c}2^{\text {nd }} \\
\text { transfer } \\
\text { baseline }\end{array}$ & $\begin{array}{c}25-41 \\
\left(\mathrm{~T}_{\mathrm{L}}\right)\end{array}$ & $\begin{array}{c}25-42 \\
\left(\mathrm{~T}_{\mathrm{L}}\right)\end{array}$ & $\begin{array}{c}25-43 \\
\left(\mathrm{~T}_{\mathrm{L}}\right)\end{array}$ & $\begin{array}{c}25-44 \\
\left(\mathrm{~T}_{\mathrm{L}}\right)\end{array}$ & $\begin{array}{c}25-45 \\
\left(T_{L}\right)\end{array}$ & $\begin{array}{l}25-43 \\
(\text { low } \eta)\end{array}$ \\
\hline Min Al & $\begin{array}{c}25-41 \\
\left(\mathrm{~T}_{\mathrm{L}}\right)\end{array}$ & $\begin{array}{c}25-42 \\
\left(\mathrm{~T}_{\mathrm{L}}\right)\end{array}$ & $\begin{array}{c}25-43 \\
\left(\mathrm{~T}_{\mathrm{L}}\right) \\
\end{array}$ & $\begin{array}{l}25-43 \\
(\text { low } \eta) \\
\end{array}$ & $\begin{array}{l}25-40 \\
(\text { low } \eta)\end{array}$ & - \\
\hline Max Al & $\begin{array}{c}\text { high } \eta) \\
26-52 \\
\left(T_{L}\right)\end{array}$ & $\begin{array}{c}25-53 \\
\left(T_{L}\right)\end{array}$ & $\begin{array}{c}25-54 \\
\left(T_{L}\right)\end{array}$ & $\begin{array}{c}25-55 \\
\left(T_{L} / \text { low } \eta\right)\end{array}$ & $\begin{array}{l}25-52 \\
\text { (low } \eta)\end{array}$ & $\begin{array}{l}25-49 \\
\text { (low } \eta)\end{array}$ \\
\hline Min $\mathrm{Ce}$ & $\begin{array}{c}25-38 \\
\left(\mathrm{~T}_{\mathrm{L}}\right)\end{array}$ & $\begin{array}{c}25-39 \\
\left(\mathrm{~T}_{\mathrm{L}}\right)\end{array}$ & $\begin{array}{c}25-40 \\
\left(\mathrm{~T}_{\mathrm{L}}\right)\end{array}$ & $\begin{array}{c}25-41 \\
\left(T_{L}\right)\end{array}$ & $\begin{array}{c}25-42 \\
\left(T_{L}\right)\end{array}$ & $\begin{array}{c}25-43 \\
\left(T_{L}\right)\end{array}$ \\
\hline $\mathrm{Min} \mathrm{Fe}$ & $\begin{array}{c}25-42 \\
\left(\mathrm{~T}_{\mathrm{L}}\right)\end{array}$ & $\begin{array}{c}25-43 \\
\left(\mathrm{~T}_{\mathrm{L}}\right)\end{array}$ & $\begin{array}{c}25-44 \\
\left(\mathrm{~T}_{\mathrm{L}}\right)\end{array}$ & $\begin{array}{c}25-45 \\
\left(\mathrm{~T}_{\mathrm{L}}\right)\end{array}$ & $\begin{array}{c}25-46 \\
\left(\mathrm{~T}_{\mathrm{L}}\right)\end{array}$ & $\begin{array}{c}25-46 \\
\left(T_{L}\right)\end{array}$ \\
\hline Max Mg & $\begin{array}{c}25-42 \\
\left(\mathrm{~T}_{\mathrm{L}}\right)\end{array}$ & $\begin{array}{c}25-43 \\
\left(T_{L}\right)\end{array}$ & $\begin{array}{c}25-44 \\
\left(T_{L}\right)\end{array}$ & $\begin{array}{c}25-45 \\
\left(T_{L} / \text { low } \eta\right)\end{array}$ & $\begin{array}{l}25-42 \\
\text { (low } \eta)\end{array}$ & $\begin{array}{c}\left(\Delta \mathrm{G}_{\mathrm{P}}\right) \\
38-39 \\
(\text { low } \eta)\end{array}$ \\
\hline Max Ni & $\begin{array}{c}25-37 \\
\left(\mathrm{~T}_{\mathrm{L}}\right)\end{array}$ & $\begin{array}{c}25-38 \\
\left(T_{L}\right)\end{array}$ & $\begin{array}{c}25-39 \\
\left(T_{L}\right)\end{array}$ & $\begin{array}{c}25-40 \\
\left(\mathrm{~T}_{\mathrm{L}}\right)\end{array}$ & $\begin{array}{c}25-41 \\
\left(T_{L}\right)\end{array}$ & $\begin{array}{c}\left(\Delta \mathrm{G}_{\mathrm{P}}\right) \\
28-41 \\
(\text { low } \eta)\end{array}$ \\
\hline Max Ti & $\begin{array}{c}25-51 \\
\left(\mathrm{~T}_{\mathrm{L}}\right)\end{array}$ & $\begin{array}{c}25-52 \\
\left(\mathrm{~T}_{\mathrm{L}}\right)\end{array}$ & $\begin{array}{c}25-53 \\
\left(T_{L} / \text { low } \eta\right)\end{array}$ & $\begin{array}{l}25-51 \\
(\text { low } \eta)\end{array}$ & $\begin{array}{l}25-48 \\
\text { (low } \eta)\end{array}$ & $\begin{array}{l}25-45 \\
\text { (low } \eta)\end{array}$ \\
\hline
\end{tabular}

Comparing the MAR based projected operating windows shown in Table 6-1 (with ARP) to those of the SB4 1100 canister options without ARP (Table 5-2) shows only a minimal impact of introducing the ARP-A stream into the SB4 flowsheet. More specifically, consider the 1100 canister baseline option. From Table 5-2, when Frits $418,426,425$, and 417 are used, the systems are $\mathrm{T}_{\mathrm{L}}$-limited (at the upper $\mathrm{WL}$ ) and have projected operating windows ranging from $25 \% \mathrm{WL}$ to $42 \%$ (with Frit 418 ) and from $25 \% \mathrm{WL}$ to $45 \%$ (with Frit 417 ) with $1 \% \mathrm{WL}$ increments for the frits in between. This shift toward higher WLs is attributed to the additional $\mathrm{Na}_{2} \mathrm{O}$ in the frit as its impact is to lower $\mathrm{T}_{\mathrm{L}}$ which provides access to higher WLs. When higher $\mathrm{Na}_{2} \mathrm{O}$-based frits are used (Frit 320 and Frit 431), the systems become low viscosity limited. This transition suggests that the glasses contain sufficient alkali to lower $T_{L}$ as well as viscosity leading to predictions of low viscosity limiting access to higher WLs. When the ARP-A stream is blended with the 1100 canister baseline option, the impacts to the projected windows are dependent upon the property limiting access to higher WLs. For those non-ARP systems which were $\mathrm{T}_{\mathrm{L}}$-limited, introduction of the ARP-A stream has no effect on the projected operating windows. For those non-ARP options which were low viscosity limited (Frit 320 and Frit 431), adding the ARP-A stream has a slightly negative impact ( $1 \%$ reduction in the upper $\mathrm{WL})$ in the projected windows. This negative impact is a result of the additional $\mathrm{Na}_{2} \mathrm{O}$ being introduced from the ARP stream which continually lowers viscosity. The additional $\mathrm{Na}_{2} \mathrm{O}$ from the ARP-A stream also results in further limitations of lower WLs due to predictions of durability $\left(\Delta \mathrm{G}_{\mathrm{P}}\right)$ (i.e., the lower WL limit increases from $27 \%$ without ARP to $31 \%$ with ARP-A). 
For select SB4 blending scenarios there is a positive impact on the addition of the ARP-A stream. Consider the "1100 canister $2^{\text {nd }}$ transfer baseline", "Min Al", "Max Al", "Min Fe", "Max Mg", "Max Ni", and "Max Ti" cases. When the non-ARP based systems are $T_{L}$ limited, introduction of the ARP-A stream has a slight positive impact on the projected windows. More specifically, a 1\% increase in the upper WL is observed for these ARP$\mathrm{A}$ based cases. This positive impact is a result of the additional $\mathrm{Na}_{2} \mathrm{O}$ from the ARP stream lowering $\mathrm{T}_{\mathrm{L}}$ which allows higher WLs to be achieved. As was observed in the 1100 canister baseline options, if the system (without ARP) was low viscosity limited, addition of the ARP stream had a slightly negative impact on the upper WL - although not severe enough to warrant eliminating this ARP option from further consideration.

Based on the MAR assessments, the ARP-A option has minimal impact on the projected operating windows and would not require a frit change to accommodate this stream. This latter statement is based solely on the model based projections and does not consider any impacts on melt rate and/or other CPC processing issues. It is interesting to note that $\mathrm{TiO}_{2}$ is not a limiting component within this system even at the $1 \% \mathrm{TiO}_{2}$ limit being used for the MAR assessments. Although not specifically tabulated, the results of the SB4-Only and 1200 canister options show no significant deviations from the general trends discussed (see Appendix A for more details).

The impacts (both positive and negative) observed with the ARP-A option are typical of all other ARP options. The difference being the magnitude of the impact which is strictly a result of the ARP nominal sludge composition and the projected blending strategy differences (i.e., volumes or masses). As previously noted, subsequent discussions will highlight the magnitude of these impacts as well as highlight any additional primary differences observed.

\subsection{ARP-E}

The projected operating windows for the 1100 canister -ARP-E options are provided in Table 6-2. The general trends for these systems are in line with the previous assessment of the ARP-A stream. These include a positive impact for those systems which were initially $T_{L}$-limited (without ARP-E included). In general, there is a $\%$ WL increase for these systems relative to the "non-ARP" based systems shown in Table 5-2. When the systems are low viscosity or durability limited, introduction of ARP-E has a negative impact which ranges from a $1-2 \%$ WL reduction to complete elimination of the projected operating window. Consider the 1100 canister baseline case when coupled with Frit 417, Frit 320, and Frit 431. When ARP-E is not present (Table 5-2), the projected operating windows are $25-45\left(\mathrm{~T}_{\mathrm{L}}\right), 24-44$ (low $\left.\eta\right)$, and $\left(\Delta \mathrm{G}_{\mathrm{P}}\right) 27-41$ (low $\left.\eta\right)$, respectively. ${ }^{8}$ When ARP-E is added, the projected operating windows are $25-44$ (low $\eta$ ), $25-42$ (low $\eta$ ), and non-existent (no operating window), respectively. The transition from a $T_{L}$ to low viscosity limited system with Frit 417 is not surprising given the additional $\mathrm{Na}_{2} \mathrm{O}$ from the ARP stream which has an anticipated slightly negative impact on the projected window. With Frit 320, including the ARP-E stream continues to lower viscosity and the negative impact to the window (relative to the non-ARP option) is a $\%$ reduction. With Frit 431, predictions of durability begin to limit lower WLs (i.e., WLs of $26 \mathrm{wt} \%$ and lower) in the non-ARP option. When the ARP-E stream is added, the projected operating window is completely eliminated. Although the specific property predictions for each glass within this system are not shown in Appendix A, the previous trends regarding the impacts of ARP suggest that the complete elimination is not associated with viscosity predictions but are durability related. That is, the increase in $\mathrm{Na}_{2} \mathrm{O}$ has a significant negative impact on durability predictions to the point of eliminating the use of Frit 431 with the 1100 canister baseline - ARP-E flowsheet. This does not suggest that the ARP-E option should be dismissed, only that if DWPF were using Frit 431 to process the 1100 canister baseline option (without ARP), a frit change would be required to transition to a "coupled" flowsheet

\footnotetext{
${ }^{8}$ The use of Frit 431 is also limited at lower WLs ( $26 \%$ and less) by predictions of durability as indicated by the $\Delta \mathrm{G}_{\mathrm{P}}$ listed before the projected operating window.
} 
based on ARP-E. 9 The model predictions also restrict the use of Frit 431 with the "Min Al", "Max Mg", and "Max Ti" cases for the ARP-E option.

Based on model predictions, introduction of the ARP-E stream is a viable option for the 1100 canister cases. Although not specifically tabulated, the results of the SB4-Only and 1200 canister options show no significant deviations from the general trends discussed. With respect to the ARP-A option, there is essentially no practical difference in the impacts to the projected windows. A choice between one of these two options should not be influenced by the model predictions, but differences could exist based on CPC processing issues or melt rate.

\footnotetext{
${ }^{9}$ Frit 431 is a viable candidate for the 1100 canister baseline option without ARP based on the model assessments provided by Peeler and Edwards (2005) and its use may lead to enhanced melt rate given the higher $\mathrm{Na}_{2} \mathrm{O}$ concentration. However, the sensitivity of the projected operating windows to slight compositional variation (either due to washing or the addition of an ARP stream) would probably result in this frit not being recommended.
} 
WSRC-TR-2005-00123

Revision 0

Table 6-2. MAR Results for the SB4 1100 Canister + ARP-E Cases

\begin{tabular}{|c|c|c|c|c|c|c|}
\hline & Frit 418 & Frit 426 & Frit 425 & Frit 417 & Frit 320 & Frit 431 \\
\hline $\begin{array}{l}\% \mathrm{Na}_{2} \mathrm{O} \\
\text { (in frit) }\end{array}$ & 8 & 9 & 10 & 11 & 12 & 13 \\
\hline Baseline & $\begin{array}{c}25-44 \\
\left(T_{L}\right)\end{array}$ & $\begin{array}{c}25-45 \\
\left(T_{L}\right)\end{array}$ & $\begin{array}{c}25-46 \\
\left(\mathrm{~T}_{\mathrm{L}}\right)\end{array}$ & $\begin{array}{l}25-44 \\
(\text { low } \eta)\end{array}$ & $\begin{array}{l}25-42 \\
(\text { low } \eta)\end{array}$ & - \\
\hline $\begin{array}{c}2^{\text {nd }} \\
\text { transfer } \\
\text { baseline }\end{array}$ & $\begin{array}{c}25-43 \\
\left(T_{L}\right)\end{array}$ & $\begin{array}{c}25-44 \\
\left(T_{L}\right)\end{array}$ & $\begin{array}{c}25-45 \\
\left(\mathrm{~T}_{\mathrm{L}}\right)\end{array}$ & $\begin{array}{c}25-45 \\
\left(\mathrm{~T}_{\mathrm{L}}\right)\end{array}$ & $\begin{array}{l}25-44 \\
\text { (low } \eta \text { ) }\end{array}$ & $\begin{array}{c}\left(\Delta \mathrm{G}_{\mathrm{P}}\right) \\
31-41 \\
(\text { low } \eta)\end{array}$ \\
\hline Min Al & $\begin{array}{c}25-42 \\
\left(T_{L}\right)\end{array}$ & $\begin{array}{c}25-43 \\
\left(T_{L}\right)\end{array}$ & $\begin{array}{c}25-44 \\
\left(T_{L} / \text { low } \eta\right)\end{array}$ & $\begin{array}{l}25-42 \\
(\text { low } \eta)\end{array}$ & $\begin{array}{l}25-39 \\
(\text { low } \eta)\end{array}$ & - \\
\hline Max Al & $\begin{array}{c}25-54 \\
\left(\mathrm{~T}_{\mathrm{L}}\right)\end{array}$ & $\begin{array}{c}25-55 \\
\left(\mathrm{~T}_{\mathrm{L}}\right)\end{array}$ & $\begin{array}{l}25-55 \\
(\text { low } \eta)\end{array}$ & $\begin{array}{l}25-52 \\
(\text { low } \eta)\end{array}$ & $\begin{array}{l}25-49 \\
(\text { low } \eta)\end{array}$ & $\begin{array}{l}25-46 \\
(\text { low } \eta)\end{array}$ \\
\hline Min $\mathrm{Ce}$ & $\begin{array}{c}25-40 \\
\left(T_{L}\right)\end{array}$ & $\begin{array}{c}25-41 \\
\left(\mathrm{~T}_{\mathrm{L}}\right)\end{array}$ & $\begin{array}{c}25-42 \\
\left(T_{L}\right)\end{array}$ & $\begin{array}{c}25-43 \\
\left(T_{L}\right)\end{array}$ & $\begin{array}{c}25-44 \\
\left(T_{L}\right)\end{array}$ & $\begin{array}{l}25-43 \\
\text { (low } \eta)\end{array}$ \\
\hline Min Fe & $\begin{array}{c}25-43 \\
\left(T_{L}\right)\end{array}$ & $\begin{array}{c}25-44 \\
\left(\mathrm{~T}_{\mathrm{L}}\right)\end{array}$ & $\begin{array}{c}25-45 \\
\left(T_{L}\right)\end{array}$ & $\begin{array}{c}25-46 \\
\left(T_{L}\right)\end{array}$ & $\begin{array}{c}25-47 \\
\left(T_{L}\right)\end{array}$ & $\begin{array}{l}25-45 \\
(\text { low } \eta)\end{array}$ \\
\hline Max Mg & $\begin{array}{c}25-44 \\
\left(T_{L}\right)\end{array}$ & $\begin{array}{c}25-45 \\
\left(\mathrm{~T}_{\mathrm{L}}\right)\end{array}$ & $\begin{array}{c}25-46 \\
\left(T_{L} / \text { low } \eta\right)\end{array}$ & $\begin{array}{l}25-44 \\
(\text { low } \eta)\end{array}$ & $\begin{array}{l}25-41 \\
(\text { low } \eta)\end{array}$ & - \\
\hline Max Ni & $\begin{array}{c}25-38 \\
\left(T_{L}\right)\end{array}$ & $\begin{array}{c}25-39 \\
\left(T_{L}\right)\end{array}$ & $\begin{array}{c}25-40 \\
\left(T_{L}\right)\end{array}$ & $\begin{array}{c}25-41 \\
\left(\mathrm{~T}_{\mathrm{L}}\right)\end{array}$ & $\begin{array}{c}25-42 \\
\left(T_{L} / \text { low } \eta\right)\end{array}$ & - \\
\hline Max Ti & $\begin{array}{c}25-52 \\
\left(T_{L}\right)\end{array}$ & $\begin{array}{c}25-53 \\
\left(T_{L}\right)\end{array}$ & $\begin{array}{l}25-51 \\
(\text { low } \eta)\end{array}$ & $\begin{array}{l}25-49 \\
(\text { low } \eta)\end{array}$ & $\begin{array}{l}25-46 \\
(\text { low } \eta)\end{array}$ & $\begin{array}{l}25-43 \\
\text { (low } \eta)\end{array}$ \\
\hline
\end{tabular}

\subsection{ARP-K}

Table 6-3 summarizes the projected operating windows for the various 1100 canister -ARP-K flowsheets. The most significant observation is that $\mathrm{TiO}_{2}$ becomes the limiting constraint for almost every system (the exception being the "Min Al" case with Frit 320, where durability limits access to WLs of 36\% and higher). Although the $\mathrm{TiO}_{2}$ content of the calcined ARP-K stream is slightly lower than that of ARP-A ( $26.4 \mathrm{wt} \%$ versus $26.8 \mathrm{wt} \%$, respectively - see Table 4-1 and Appendix A), the ARP stream volume associated with this case is much higher. Therefore, the $\mathrm{TiO}_{2}$ in the final blended SRAT product (SB4 with ARP-K) is much higher and exceeds the 1 $\mathrm{wt} \%$ limit at approximately $39 \% \mathrm{WL}$ (once the MAR uncertainty is applied), regardless of the SB4 blending option or frit selection.

When the $\mathrm{TiO}_{2}$ limit is increased to $2 \mathrm{wt} \%$ in PCCS , the primary properties limiting access to higher WLs transition back to either $\mathrm{T}_{\mathrm{L}}$ or low viscosity resulting in "more typical" projected operating windows (see Table 6-4). When comparing the ARP-K impact (with the $2 \mathrm{wt} \% \mathrm{TiO}_{2}$ limit) with the 1100 canister options (shown in Table 5-2), there is a significant, positive impact on the projected windows for those systems which were $T_{L^{-}}$ limited prior to the introduction of the ARP stream. More specifically, an approximate $4 \mathrm{wt} \%$ increase in the upper WL is observed relative to those same systems without ARP added. As observed with ARP-A and ARP$\mathrm{E}$, when the non-ARP flowsheet is low viscosity limited, the impact of adding the ARP-K stream is typically a $2 \% \mathrm{WL}$ reduction in the upper WL defining the projected operating window. For those non-ARP systems in which predictions of durability limit some portion of the $25-60 \%$ window, once the ARP-K stream is added, complete elimination of the projected operating windows occurs. It is also interesting to note that for some of 
the initial systems (without ARP) that were $\mathrm{T}_{\mathrm{L}}$-limited, addition of ARP-K transitions these systems to durability limited (not low viscosity limited as previously observed) which results in impacts ranging from slight to significant depending on the specific SB4 option and frit being considered. The impact of ARP-K to systems that were low viscosity limited is more significant than observed in previous systems. Again, the results of the SB4-Only and 1200 canister options show no significant deviations from the general trends discussed.

Based on model-predictions, introduction of ARP-K to the SB4 options would require an increase in the current $\mathrm{PCCS} \mathrm{TiO}_{2}$ limit from $1 \mathrm{wt} \%$ to $2 \mathrm{wt} \%$ (if WLs targeting 39\% or greater are desired). With this increase, there appear to be some advantages of this ARP stream relative to the other options (including ARP-M and ARP-V not discussed as of yet). This advantage is based on the $\sim 4 \%$ increase in the upper WL defining the projected window for most of the options being considered (which were initially $\mathrm{T}_{\mathrm{L}}$ limited). Although potentially advantageous for some frit/sludge combinations, the addition of the ARP-K stream could be devastating to other systems if compositional adjustments are not made (i.e., a frit change). Frits could be selected that are robust to the inclusion of the ARP, but they may not be optimized for other properties (e.g., melt rate). Again, this report only assesses the impact on the projected operating windows and the impacts of ARP-K on melt rate or other $\mathrm{CPC}$ processing issues must also be considered as part of the overall evaluation.

Table 6-3. MAR Results for the SB4 1100 Canister + ARP-K Cases

\begin{tabular}{|c|c|c|c|c|c|c|}
\hline & Frit 418 & Frit 426 & Frit 425 & Frit 417 & Frit 320 & Frit 431 \\
\hline $\begin{array}{l}\% \mathrm{Na}_{2} \mathrm{O} \\
\text { (in frit) }\end{array}$ & 8 & 9 & 10 & 11 & 12 & 13 \\
\hline Baseline & $\begin{array}{c}25-39 \\
\left(\mathrm{TiO}_{2}\right) \\
\end{array}$ & $\begin{array}{c}25-39 \\
\left(\mathrm{TiO}_{2}\right)\end{array}$ & $\begin{array}{c}25-39 \\
\left(\mathrm{TiO}_{2}\right) \\
\end{array}$ & $\begin{array}{c}25-39 \\
\left(\mathrm{TiO}_{2}\right)\end{array}$ & $\begin{array}{c}25-39 \\
\left(\mathrm{TiO}_{2}\right) \\
\end{array}$ & - \\
\hline $\begin{array}{c}2^{\text {nd }} \\
\text { transfer } \\
\text { baseline }\end{array}$ & $\begin{array}{c}25-39 \\
\left(\mathrm{TiO}_{2}\right)\end{array}$ & $\begin{array}{c}25-39 \\
\left(\mathrm{TiO}_{2}\right)\end{array}$ & $\begin{array}{c}25-39 \\
\left(\mathrm{TiO}_{2}\right)\end{array}$ & $\begin{array}{c}25-39 \\
\left(\mathrm{TiO}_{2}\right)\end{array}$ & $\begin{array}{c}25-39 \\
\left(\mathrm{TiO}_{2}\right)\end{array}$ & - \\
\hline Min Al & $\begin{array}{c}25-39 \\
\left(\mathrm{TiO}_{2}\right)\end{array}$ & $\begin{array}{c}25-39 \\
\left(\mathrm{TiO}_{2}\right)\end{array}$ & $\begin{array}{c}25-39 \\
\left(\mathrm{TiO}_{2}\right)\end{array}$ & $\begin{array}{c}25-39 \\
\left(\mathrm{TiO}_{2}\right)\end{array}$ & $\begin{array}{c}25-35 \\
\left(\Delta \mathrm{G}_{\mathrm{P}}\right)\end{array}$ & - \\
\hline Max Al & $\begin{array}{c}25-39 \\
\left(\mathrm{TiO}_{2}\right)\end{array}$ & $\begin{array}{c}25-39 \\
\left(\mathrm{TiO}_{2}\right)\end{array}$ & $\begin{array}{c}25-39 \\
\left(\mathrm{TiO}_{2}\right)\end{array}$ & $\begin{array}{c}25-39 \\
\left(\mathrm{TiO}_{2}\right)\end{array}$ & $\begin{array}{c}25-39 \\
\left(\mathrm{TiO}_{2}\right)\end{array}$ & $\begin{array}{c}25-39 \\
\left(\mathrm{TiO}_{2}\right)\end{array}$ \\
\hline Min $\mathrm{Ce}$ & $\begin{array}{c}25-39 \\
\left(\mathrm{TiO}_{2}\right)\end{array}$ & $\begin{array}{c}25-39 \\
\left(\mathrm{TiO}_{2}\right)\end{array}$ & $\begin{array}{c}25-39 \\
\left(\mathrm{TiO}_{2}\right)\end{array}$ & $\begin{array}{c}25-39 \\
\left(\mathrm{TiO}_{2}\right)\end{array}$ & $\begin{array}{c}25-39 \\
\left(\mathrm{TiO}_{2}\right)\end{array}$ & $\begin{array}{c}\left(\Delta \mathrm{G}_{\mathrm{P}}\right) \\
31-39 \\
\left(\mathrm{TiO}_{2}\right) \\
\end{array}$ \\
\hline Min $\mathrm{Fe}$ & $\begin{array}{c}25-39 \\
\left(\mathrm{TiO}_{2}\right)\end{array}$ & $\begin{array}{c}25-39 \\
\left(\mathrm{TiO}_{2}\right)\end{array}$ & $\begin{array}{c}25-39 \\
\left(\mathrm{TiO}_{2}\right)\end{array}$ & $\begin{array}{c}25-39 \\
\left(\mathrm{TiO}_{2}\right)\end{array}$ & $\begin{array}{c}25-39 \\
\left(\mathrm{TiO}_{2}\right)\end{array}$ & $\begin{array}{c}\left(\Delta \mathrm{G}_{\mathrm{P}}\right) \\
26-39 \\
\left(\mathrm{TiO}_{2}\right)\end{array}$ \\
\hline Max Mg & $\begin{array}{c}25-39 \\
\left(\mathrm{TiO}_{2}\right) \\
\end{array}$ & $\begin{array}{c}25-39 \\
\left(\mathrm{TiO}_{2}\right) \\
\end{array}$ & $\begin{array}{c}25-39 \\
\left(\mathrm{TiO}_{2}\right) \\
\end{array}$ & $\begin{array}{c}25-39 \\
\left(\mathrm{TiO}_{2}\right) \\
\end{array}$ & $\begin{array}{c}25-39 \\
\left(\mathrm{TiO}_{2}\right) \\
\end{array}$ & - \\
\hline Max Ni & $\begin{array}{c}25-39 \\
\left(\mathrm{TiO}_{2}\right) \\
\end{array}$ & $\begin{array}{c}25-39 \\
\left(\mathrm{TiO}_{2}\right) \\
\end{array}$ & $\begin{array}{c}25-39 \\
\left(\mathrm{TiO}_{2}\right) \\
\end{array}$ & $\begin{array}{c}25-39 \\
\left(\mathrm{TiO}_{2}\right) \\
\end{array}$ & $\begin{array}{c}25-39 \\
\left(\mathrm{TiO}_{2}\right) \\
\end{array}$ & - \\
\hline Max Ti & $\begin{array}{c}25-39 \\
\left(\mathrm{TiO}_{2}\right)\end{array}$ & $\begin{array}{c}25-39 \\
\left(\mathrm{TiO}_{2}\right)\end{array}$ & $\begin{array}{c}25-39 \\
\left(\mathrm{TiO}_{2}\right)\end{array}$ & $\begin{array}{c}25-39 \\
\left(\mathrm{TiO}_{2}\right)\end{array}$ & $\begin{array}{c}25-39 \\
\left(\mathrm{TiO}_{2}\right)\end{array}$ & $\begin{array}{c}\left(\Delta \mathrm{G}_{\mathrm{P}}\right) \\
30-39 \\
\left(\mathrm{TiO}_{2}\right) \\
\end{array}$ \\
\hline
\end{tabular}


WSRC-TR-2005-00123

Revision 0

Table 6-4. MAR Results for the SB4 1100 Canister + ARP-K Cases (2 wt\% $\mathrm{TiO}_{2}$ Limit)

\begin{tabular}{|c|c|c|c|c|c|c|}
\hline & Frit 418 & Frit 426 & Frit 425 & Frit 417 & Frit 320 & Frit 431 \\
\hline $\begin{array}{l}\% \mathrm{Na}_{2} \mathrm{O} \\
\text { (in frit) }\end{array}$ & 8 & 9 & 10 & 11 & 12 & 13 \\
\hline Baseline & $\begin{array}{c}25-46 \\
\left(T_{L}\right)\end{array}$ & $\begin{array}{c}25-47 \\
\left(\mathrm{~T}_{\mathrm{L}}\right)\end{array}$ & $\begin{array}{l}25-46 \\
(\text { low } \eta)\end{array}$ & $\begin{array}{l}25-43 \\
(\text { low } \eta)\end{array}$ & $\begin{array}{l}25-41 \\
(\text { low } \eta)\end{array}$ & - \\
\hline $\begin{array}{c}2^{\text {nd }} \\
\text { transfer } \\
\text { baseline }\end{array}$ & $\begin{array}{c}25-44 \\
\left(T_{L}\right)\end{array}$ & $\begin{array}{c}25-45 \\
\left(T_{L}\right)\end{array}$ & $\begin{array}{c}25-46 \\
\left(T_{L}\right)\end{array}$ & $\begin{array}{l}25-46 \\
(\text { low } \eta)\end{array}$ & $\begin{array}{l}25-43 \\
\text { (low } \eta)\end{array}$ & - \\
\hline Min Al & $\begin{array}{c}25-44 \\
\left(T_{L}\right)\end{array}$ & $\begin{array}{c}25-45 \\
\left(\mathrm{~T}_{\mathrm{L}}\right)\end{array}$ & $\begin{array}{l}25-44 \\
(\text { low } \eta)\end{array}$ & $\begin{array}{l}25-41 \\
(\text { low } \eta)\end{array}$ & $\begin{array}{c}25-35 \\
\left(\Delta \mathrm{G}_{\mathrm{P}}\right)\end{array}$ & - \\
\hline $\operatorname{Max} \mathrm{Al}$ & $\begin{array}{c}25-56 \\
\left(T_{L}\right)\end{array}$ & $\begin{array}{l}25-55 \\
(\text { low } \eta)\end{array}$ & $\begin{array}{l}25-53 \\
(\text { low } \eta)\end{array}$ & $\begin{array}{l}25-51 \\
(\text { low } \eta)\end{array}$ & $\begin{array}{l}25-48 \\
(\text { low } \eta)\end{array}$ & $\begin{array}{l}25-45 \\
\text { (low } \eta)\end{array}$ \\
\hline Min $\mathrm{Ce}$ & $\begin{array}{c}25-41 \\
\left(\mathrm{~T}_{\mathrm{L}}\right)\end{array}$ & $\begin{array}{c}25-42 \\
\left(\mathrm{~T}_{\mathrm{L}}\right)\end{array}$ & $\begin{array}{c}25-43 \\
\left(T_{L}\right)\end{array}$ & $\begin{array}{c}25-44 \\
\left(T_{L}\right)\end{array}$ & $\begin{array}{c}25-45 \\
\left(T_{L} / \text { low }\right. \\
\eta)\end{array}$ & $\begin{array}{c}\left(\Delta \mathrm{G}_{\mathrm{P}}\right) \\
31-42 \\
(\text { low } \eta)\end{array}$ \\
\hline Min Fe & $\begin{array}{c}25-45 \\
\left(\mathrm{~T}_{\mathrm{L}}\right)\end{array}$ & $\begin{array}{c}25-46 \\
\left(T_{L}\right)\end{array}$ & $\begin{array}{c}25-47 \\
\left(T_{L}\right)\end{array}$ & $\begin{array}{c}25-48 \\
\left(\mathrm{~T}_{\mathrm{L}}\right)\end{array}$ & $\begin{array}{l}25-46 \\
(\text { low } \eta)\end{array}$ & $\begin{array}{c}\left(\Delta \mathrm{G}_{\mathrm{P}}\right) \\
26-43 \\
(\text { low } \eta) \\
\end{array}$ \\
\hline Max Mg & $\begin{array}{c}25-45 \\
\left(T_{L}\right)\end{array}$ & $\begin{array}{c}25-46 \\
\left(T_{L}\right)\end{array}$ & $\begin{array}{l}25-45 \\
(\text { low } \eta)\end{array}$ & $\begin{array}{l}25-43 \\
\text { (low } \eta)\end{array}$ & $\begin{array}{l}25-40 \\
(\text { low } \eta)\end{array}$ & - \\
\hline Max Ni & $\begin{array}{c}25-40 \\
\left(\mathrm{~T}_{\mathrm{L}}\right)\end{array}$ & $\begin{array}{c}25-41 \\
\left(\mathrm{~T}_{\mathrm{L}}\right)\end{array}$ & $\begin{array}{c}25-42 \\
\left(T_{L}\right)\end{array}$ & $\begin{array}{c}25-43 \\
\left(\mathrm{~T}_{\mathrm{L}}\right)\end{array}$ & $\begin{array}{l}25-42 \\
(\text { low } \eta)\end{array}$ & - \\
\hline Max Ti & $\begin{array}{c}25-54 \\
\left(T_{L} / \text { low } \eta\right)\end{array}$ & $\begin{array}{l}25-52 \\
\text { (low } \eta)\end{array}$ & $\begin{array}{l}25-50 \\
\text { (low } \eta)\end{array}$ & $\begin{array}{l}25-48 \\
\text { (low } \eta)\end{array}$ & $\begin{array}{l}25-45 \\
(\text { low } \eta \text { ) }\end{array}$ & $\begin{array}{c}\left(\Delta \mathrm{G}_{\mathrm{P}}\right) \\
30-42 \\
(\text { low } \eta) \\
\end{array}$ \\
\hline
\end{tabular}

\subsection{ARP-M}

Table 6-5 summarizes the projected operating windows for the SB4 1100 canister options with ARP-M. Introduction of ARP-M results in very similar effects as were observed with ARP-A and ARP-E. More specifically, for those systems which were $\mathrm{T}_{\mathrm{L}}$ limited without the ARP stream, the upper WL that can be achieved is typically increased by $1-2 \%$. For those systems which were low viscosity limited, the introduction of the ARP-M stream results in a slightly negative impact to the upper WL.

As shown in Table 4-1, the $\mathrm{TiO}_{2}$ concentration in ARP-M is $0.00 \mathrm{wt} \%$ therefore, the use of the $1 \mathrm{wt} \% \mathrm{TiO}_{2}$ limit did not constrain any of the windows. As with previous systems, the introduction of additional $\mathrm{Na}_{2} \mathrm{O}$ via the ARP stream restricts the use of Frit 431 for most systems. Coupling the high alkali frit with enriched alkali sludges results in predictions of durability shutting down projected operating windows or drastically reducing their size. Although not specifically tabulated, the results of the SB4-Only and 1200 canister options show no significant deviations from the general trends discussed with the inclusion of the ARP-M option. 
Table 6-5. MAR Results for the SB4 1100 Canister + ARP-M Cases

\begin{tabular}{|c|c|c|c|c|c|c|}
\hline & Frit 418 & Frit 426 & Frit 425 & Frit 417 & Frit 320 & Frit 431 \\
\hline $\begin{array}{l}\% \mathrm{Na}_{2} \mathrm{O} \\
\text { (in frit) }\end{array}$ & 8 & 9 & 10 & 11 & 12 & 13 \\
\hline Baseline & $\begin{array}{c}25-43 \\
\left(T_{L}\right)\end{array}$ & $\begin{array}{c}25-44 \\
\left(\mathrm{~T}_{\mathrm{L}}\right)\end{array}$ & $\begin{array}{c}25-45 \\
\left(\mathrm{~T}_{\mathrm{L}}\right)\end{array}$ & $\begin{array}{l}25-45 \\
\text { (low } \eta)\end{array}$ & $\begin{array}{l}25-42 \\
(\text { low } \eta)\end{array}$ & - \\
\hline $\begin{array}{l}2^{\text {nd }} \\
\text { transfer } \\
\text { baseline }\end{array}$ & $\begin{array}{c}25-42 \\
\left(T_{L}\right)\end{array}$ & $\begin{array}{c}25-43 \\
\left(\mathrm{~T}_{\mathrm{L}}\right)\end{array}$ & $\begin{array}{c}25-44 \\
\left(T_{L}\right)\end{array}$ & $\begin{array}{c}25-45 \\
\left(\mathrm{~T}_{\mathrm{L}}\right)\end{array}$ & $\begin{array}{c}25-45 \\
\left(T_{L} / \text { low } \eta\right)\end{array}$ & $\begin{array}{c}\left(\Delta \mathrm{G}_{\mathrm{P}}\right) \\
31-41 \\
(\text { low } \eta)\end{array}$ \\
\hline Min Al & $\begin{array}{c}25-41 \\
\left(\mathrm{~T}_{\mathrm{L}}\right)\end{array}$ & $\begin{array}{c}25-42 \\
\left(T_{L}\right)\end{array}$ & $\begin{array}{c}25-43 \\
\left(\mathrm{~T}_{\mathrm{L}}\right)\end{array}$ & $\begin{array}{l}25-42 \\
(\text { low } \eta)\end{array}$ & $\begin{array}{l}25-40 \\
\text { (low } \eta)\end{array}$ & - \\
\hline $\operatorname{Max} \mathrm{Al}$ & $\begin{array}{c}25-53 \\
\left(\mathrm{~T}_{\mathrm{L}}\right)\end{array}$ & $\begin{array}{c}25-54 \\
\left(\mathrm{~T}_{\mathrm{L}}\right)\end{array}$ & $\begin{array}{c}25-55 \\
\left(T_{L} / \text { low } \eta\right)\end{array}$ & $\begin{array}{l}25-53 \\
(\text { low } \eta)\end{array}$ & $\begin{array}{l}25-50 \\
(\text { low } \eta)\end{array}$ & $\begin{array}{l}25-47 \\
\text { (low } \eta \text { ) }\end{array}$ \\
\hline Min $\mathrm{Ce}$ & $\begin{array}{c}25-39 \\
\left(\mathrm{~T}_{\mathrm{L}}\right)\end{array}$ & $\begin{array}{c}25-40 \\
\left(\mathrm{~T}_{\mathrm{L}}\right)\end{array}$ & $\begin{array}{c}25-41 \\
\left(\mathrm{~T}_{\mathrm{L}}\right)\end{array}$ & $\begin{array}{c}25-42 \\
\left(T_{L}\right)\end{array}$ & $\begin{array}{c}25-43 \\
\left(\mathrm{~T}_{\mathrm{L}}\right)\end{array}$ & $\begin{array}{c}25-44 \\
\left(T_{L} / \text { low } \eta\right)\end{array}$ \\
\hline Min Fe & $\begin{array}{c}25-43 \\
\left(T_{L}\right)\end{array}$ & $\begin{array}{c}25-43 \\
\left(\mathrm{~T}_{\mathrm{L}}\right)\end{array}$ & $\begin{array}{c}25-44 \\
\left(\mathrm{~T}_{\mathrm{L}}\right)\end{array}$ & $\begin{array}{c}25-45 \\
\left(\mathrm{~T}_{\mathrm{L}}\right)\end{array}$ & $\begin{array}{c}25-46 \\
\left(\mathrm{~T}_{\mathrm{L}}\right)\end{array}$ & $\begin{array}{l}25-45 \\
\text { (low } \eta \text { ) }\end{array}$ \\
\hline Max Mg & $\begin{array}{c}25-43 \\
\left(\mathrm{~T}_{\mathrm{L}}\right)\end{array}$ & $\begin{array}{c}25-44 \\
\left(\mathrm{~T}_{\mathrm{L}}\right) \\
\end{array}$ & $\begin{array}{c}25-45 \\
\left(\mathrm{~T}_{\mathrm{L}}\right)\end{array}$ & $\begin{array}{l}25-44 \\
\text { (low } \eta)\end{array}$ & $\begin{array}{l}25-41 \\
(\text { low } \eta)\end{array}$ & - \\
\hline Max Ni & $\begin{array}{c}25-38 \\
\left(\mathrm{~T}_{\mathrm{L}}\right) \\
\end{array}$ & $\begin{array}{c}25-39 \\
\left(\mathrm{~T}_{\mathrm{L}}\right)\end{array}$ & $\begin{array}{c}25-40 \\
\left(\mathrm{~T}_{\mathrm{L}}\right) \\
\end{array}$ & $\begin{array}{c}25-40 \\
\left(\mathrm{~T}_{\mathrm{L}}\right)\end{array}$ & $\begin{array}{c}25-41 \\
\left(\mathrm{~T}_{\mathrm{L}}\right)\end{array}$ & - \\
\hline Max Ti & $\begin{array}{c}25-51 \\
\left(\mathrm{~T}_{\mathrm{L}}\right)\end{array}$ & $\begin{array}{c}25-52 \\
\left(\mathrm{~T}_{\mathrm{L}}\right)\end{array}$ & $\begin{array}{l}25-52 \\
(\text { low } \eta)\end{array}$ & $\begin{array}{l}25-49 \\
(\text { low } \eta)\end{array}$ & $\begin{array}{l}25-47 \\
\text { (low } \eta \text { ) }\end{array}$ & $\begin{array}{l}25-43 \\
(\text { low } \eta)\end{array}$ \\
\hline
\end{tabular}




\subsection{ARP-V}

The last ARP stream to be assessed is ARP-V. The projected operating windows for the SB4 1100 canister options with ARP-V are shown in Table 6-6. In general, a 3\% WL increase is shown relative to the 1100 canister options that were $T_{L}$ limited (see Table 5-2). Again, the enhancement to the projected operating windows is consistent with previous assessments. For those non-ARP based systems that are low viscosity limited, the impact is typically a $2-4 \%$ reduction in the upper WLs achievable. As previously observed, for those non-ARP systems where durability was an issue, addition of the ARP-V stream results in a dramatic reduction if not complete elimination of the projected operating windows.

Table 6-6. MAR Results for the SB4 1100 Canister + ARP-V Cases

\begin{tabular}{|c|c|c|c|c|c|c|}
\hline & Frit 418 & Frit 426 & Frit 425 & Frit 417 & Frit 320 & Frit 431 \\
\hline $\begin{array}{l}\% \mathrm{Na}_{2} \mathrm{O} \\
\text { (in frit) }\end{array}$ & 8 & 9 & 10 & 11 & 12 & 13 \\
\hline Baseline & $\begin{array}{c}25-45 \\
\left(\mathrm{~T}_{\mathrm{L}}\right)\end{array}$ & $\begin{array}{c}25-46 \\
\left(\mathrm{~T}_{\mathrm{L}}\right) \\
\end{array}$ & $\begin{array}{c}25-47 \\
\left(T_{L} / \text { low } \eta\right)\end{array}$ & $\begin{array}{l}25-44 \\
\text { (low } \eta)\end{array}$ & $\begin{array}{l}25-41 \\
(\text { low } \eta)\end{array}$ & - \\
\hline $\begin{array}{c}2^{\text {nd }} \\
\text { transfer } \\
\text { baseline }\end{array}$ & $\begin{array}{c}25-43 \\
\left(T_{L}\right)\end{array}$ & $\begin{array}{c}25-44 \\
\left(\mathrm{~T}_{\mathrm{L}}\right)\end{array}$ & $\begin{array}{c}25-45 \\
\left(\mathrm{~T}_{\mathrm{L}}\right)\end{array}$ & $\begin{array}{c}25-46 \\
\left(\mathrm{~T}_{\mathrm{L}}\right)\end{array}$ & $\begin{array}{l}25-44 \\
\text { (low } \eta)\end{array}$ & $\begin{array}{c}\left(\Delta \mathrm{G}_{\mathrm{P}}\right) \\
33-41 \\
(\text { low } \eta) \\
\end{array}$ \\
\hline Min $\mathrm{Al}$ & $\begin{array}{c}25-43 \\
\left(\mathrm{~T}_{\mathrm{L}}\right) \\
\end{array}$ & $\begin{array}{c}25-44 \\
\left(\mathrm{~T}_{\mathrm{L}}\right) \\
\end{array}$ & $\begin{array}{l}25-44 \\
(\text { low } \eta)\end{array}$ & $\begin{array}{l}25-42 \\
(\text { low } \eta)\end{array}$ & $\begin{array}{l}25-39 \\
(\text { low } \eta)\end{array}$ & - \\
\hline $\operatorname{Max} \mathrm{Al}$ & $\begin{array}{c}25-51 \\
\left(\mathrm{TiO}_{2}\right)\end{array}$ & $\begin{array}{l}25-51 \\
\left(\mathrm{TiO}_{2}\right)\end{array}$ & $\begin{array}{c}25-51 \\
\left(\mathrm{TiO}_{2}\right)\end{array}$ & $\begin{array}{c}25-51 \\
\left(\mathrm{TiO}_{2}\right) \\
\end{array}$ & $\begin{array}{l}25-49 \\
\text { (low } \eta)\end{array}$ & $\begin{array}{l}25-46 \\
\text { (low } \eta)\end{array}$ \\
\hline Min Ce & $\begin{array}{c}25-40 \\
\left(T_{L}\right)\end{array}$ & $\begin{array}{c}25-41 \\
\left(\mathrm{~T}_{\mathrm{L}}\right)\end{array}$ & $\begin{array}{c}25-42 \\
\left(\mathrm{~T}_{\mathrm{L}}\right)\end{array}$ & $\begin{array}{c}25-43 \\
\left(\mathrm{~T}_{\mathrm{L}}\right)\end{array}$ & $\begin{array}{c}25-44 \\
\left(\mathrm{~T}_{\mathrm{L}}\right)\end{array}$ & $\begin{array}{c}\left(\Delta \mathrm{G}_{\mathrm{P}}\right) \\
26-43 \\
(\text { low } \eta)\end{array}$ \\
\hline Min Fe & $\begin{array}{c}25-45 \\
\left(\mathrm{~T}_{\mathrm{L}}\right) \\
\end{array}$ & $\begin{array}{c}25-45 \\
\left(\mathrm{~T}_{\mathrm{L}}\right) \\
\end{array}$ & $\begin{array}{c}25-46 \\
\left(\mathrm{~T}_{\mathrm{L}}\right) \\
\end{array}$ & $\begin{array}{c}25-47 \\
\left(\mathrm{~T}_{\mathrm{L}}\right) \\
\end{array}$ & $\begin{array}{c}25-47 \\
\left(T_{L}\right) \\
\end{array}$ & $\begin{array}{l}25-44 \\
(\text { low } \eta)\end{array}$ \\
\hline Max Mg & $\begin{array}{c}25-45 \\
\left(\mathrm{~T}_{\mathrm{L}}\right)\end{array}$ & $\begin{array}{c}25-45 \\
\left(T_{L}\right) \\
\end{array}$ & $\begin{array}{c}25-46 \\
\left(\mathrm{~T}_{\mathrm{L}}\right)\end{array}$ & $\begin{array}{l}25-43 \\
(\text { low } \eta)\end{array}$ & $\begin{array}{l}25-41 \\
(\text { low } \eta)\end{array}$ & - \\
\hline Max Ni & $\begin{array}{c}25-39 \\
\left(\mathrm{~T}_{\mathrm{L}}\right)\end{array}$ & $\begin{array}{c}25-40 \\
\left(\mathrm{~T}_{\mathrm{L}}\right) \\
\end{array}$ & $\begin{array}{c}25-41 \\
\left(\mathrm{~T}_{\mathrm{L}}\right)\end{array}$ & $\begin{array}{c}25-42 \\
\left(\mathrm{~T}_{\mathrm{L}}\right) \\
\end{array}$ & $\begin{array}{l}25-42 \\
(\text { low } \eta)\end{array}$ & - \\
\hline Max Ti & $\begin{array}{c}25-51 \\
\left(\mathrm{TiO}_{2}\right) \\
\end{array}$ & $\begin{array}{c}25-51 \\
\left(\mathrm{TiO}_{2}\right) \\
\end{array}$ & $\begin{array}{c}25-51 \\
\left(\mathrm{TiO}_{2} / \text { low } \eta\right)\end{array}$ & $\begin{array}{l}25-49 \\
\text { (low } \eta)\end{array}$ & $\begin{array}{l}25-46 \\
\text { (low } \eta)\end{array}$ & $\begin{array}{l}25-43 \\
(\text { low } \eta) \\
\end{array}$ \\
\hline
\end{tabular}

Other interesting systems based on the ARP-V stream include the "Max Al" and "Max Ti" blending options (see "yellow" shaded cells). The $1 \mathrm{wt} \% \mathrm{TiO}_{2}$ limit becomes the limiting constraint at WLs of $52 \%$ or greater for these options (compared to the $39 \%$ WL with the ARP-K scenarios - the differences being that the ARP-V blended SRAT product contains significantly less $\mathrm{TiO}_{2}$ allowing access to higher WLs prior to reaching the 1 $\mathrm{wt} \%$ limit). If the $\mathrm{TiO}_{2}$ limit were increased to $2 \mathrm{wt} \%$, the projected operating windows would revert back to being either $\mathrm{T}_{\mathrm{L}}$ or low viscosity limited (see Table 6-7) for these two SB4 blending options. The "revised" projected operating windows indicate that upper WLs for these systems could be increased by $1-4 \%$ (depending upon the frit) with the change to the $\mathrm{PCCS} \mathrm{TiO}_{2}$ constraint. The results of the SB4-Only and 1200 
WSRC-TR-2005-00123

Revision 0

canister options show no significant deviations from the general trends discussed with the inclusion of the ARPV option.

\section{Table 6-7. MAR Results for the SB4 1100 Canister + ARP-V for the "Max Al" and "Max Ti" Blending Options (2 wt\% $\mathrm{TiO}_{2}$ Limit)}

\begin{tabular}{||c|c|c|c|c|c|c||}
\hline & Frit 418 & Frit 426 & Frit 425 & Frit 417 & Frit 320 & Frit 431 \\
\hline $\begin{array}{c}\% \mathrm{Na}_{2} \mathrm{O} \\
\text { (in frit) }\end{array}$ & 8 & 9 & 10 & 11 & 12 & 13 \\
\hline Max Al & $\begin{array}{c}25-55 \\
\left(\mathrm{~T}_{\mathrm{L}}\right)\end{array}$ & $\begin{array}{c}25-55 \\
\left(\mathrm{~T}_{\mathrm{L}}\right)\end{array}$ & $\begin{array}{c}25-54 \\
(\text { low } \eta)\end{array}$ & $\begin{array}{c}25-52 \\
(\text { low } \eta)\end{array}$ & $\begin{array}{c}25-49 \\
(\text { low } \eta)\end{array}$ & $\begin{array}{c}25-46 \\
(\text { low } \eta)\end{array}$ \\
\hline Max Ti & $\begin{array}{c}25-53 \\
\left(\mathrm{~T}_{\mathrm{L}}\right)\end{array}$ & $\begin{array}{c}25-53 \\
(\text { low } \eta)\end{array}$ & $\begin{array}{c}25-51 \\
(\text { low } \eta)\end{array}$ & $\begin{array}{c}25-49 \\
(\text { low } \eta)\end{array}$ & $\begin{array}{c}25-46 \\
(\text { low } \eta)\end{array}$ & $\begin{array}{c}25-43 \\
(\text { low } \eta)\end{array}$ \\
\hline
\end{tabular}

\subsection{Impact of $\mathrm{SO}_{4}$ Solubility}

As mentioned in Section 3.0, the PCCS SO 4 limit for SB4 has not been established at this point but it is recognized that there is the potential that this limit could have negative impacts on the projected operating windows. The projected operating windows presented in the previous sections were based on compositions including $\mathrm{SO}_{4}$ concentrations in glass but an assumed $\mathrm{SO}_{4}$ limit was not used as a restriction. Given there is no MAR uncertainty associated with the $\mathrm{SO}_{4}$ concentration, the maximum WL for each $\mathrm{SB} 4$ option can be determined as a function of an assumed $\mathrm{SO}_{4}$ solubility limit based strictly on mathematics (i.e., the assumed $\mathrm{SO}_{4}$ solubility limit divided by the $\mathrm{SO}_{4}$ concentration in sludge times 100). For example, the normalized $\mathrm{SO}_{4}$ concentration in the 1100 canister baseline sludge was $1.099 \mathrm{wt} \%$ and assuming the $\mathrm{PCCS} \mathrm{SO}_{4}$ solubility limit was established at $0.4 \mathrm{wt} \%$ (in glass), then the maximum WL achievable (based strictly on the $\mathrm{SO}_{4}$ solubility limit) would be $36.4 \%$. Table 5-2 indicates that the projected operating windows range from $25 \% \mathrm{WL}$ to $42 \%$ (or greater) for most of the frits evaluated. Imposing a $0.4 \mathrm{wt} \% \mathrm{SO}_{4}$ limit, these windows would transition from $\mathrm{T}_{\mathrm{L}}$ or low viscosity limited to $\mathrm{SO}_{4}$ limited at $36 \% \mathrm{WL}$. That is, regardless of the frit compositions utilized, the operating windows would be restricted to $36 \%$ or less for the 1100 canister baseline sludge. Increasing the $\mathrm{PCCS} \mathrm{SO}_{4}$ limit to 0.5 or $0.6 \mathrm{wt} \%$ allows WLs of 45 and $55 \%$, respectively, prior to $\mathrm{SO}_{4}$ becoming a limiting constraint. These $\mathrm{SO}_{4}$ solubility limits do not restrict the projected operating windows. Table 6-8 summarizes the maximum WLs achievable for the 1100 canister baseline options with and without the 5 ARP streams as a function of an assumed PCCS SO 4 limit. Given each of the ARP options adds $\mathrm{SO}_{4}$ to the flowsheet, the impact on the projected operating windows relative to the 1100 canister baseline case (without ARP) is negative for a given (or assumed) $\mathrm{SO}_{4}$ limit. The projected operating windows are negatively affected with both the 0.4 and $0.5 \mathrm{wt} \%$ limits - one possible exception is the ARP-A case at a $0.5 \mathrm{wt} \%$ limit when coupled with select frits. However, using a $0.6 \mathrm{wt} \%$ limit the projected operating windows are not $\mathrm{SO}_{4}$ limited but transition back to either $\mathrm{T}_{\mathrm{L}}$ or low viscosity limited systems.

Appendix C summarizes the maximum WLs achievable for all of the SB4 blending options with each of the ARP streams as a function of the assumed $\mathrm{SO}_{4}$ solubility limits. Obviously, the number of comparisons that could be made are large but the information is provided so specific systems could be evaluated as warranted. 
WSRC-TR-2005-00123

Revision 0

Table 6-8. The Impact of $\mathrm{SO}_{4}$ of the Projected Operating Windows

\begin{tabular}{|c|c|c|c|c||}
\hline \hline & Sludge & MAX & MAX & MAX \\
Type & WL & WL & WL & WL \\
\hline 1100 Can Baseline & $\left.\mathbf{~}_{\mathbf{4}} \mathbf{0}\right)$ & $\mathbf{0 . 4}$ & $\mathbf{0 . 5}$ & $\mathbf{0 . 6}$ \\
\hline SB4 1100 Can Baseline + ARP-A SRAT Product Solids & 1.099 & 36.4 & 45.5 & 54.6 \\
\hline SB4 1100 Can Baseline + ARP-E SRAT Product Solids & 1.228 & 35.4 & 44.2 & 53.0 \\
\hline SB4 1100 Can Baseline + ARP-K SRAT Product Solids & 1.264 & 31.7 & 40.7 & 48.9 \\
\hline SB4 1100 Can Baseline + ARP-M SRAT Product Solids & 1.212 & 33.0 & 41.3 & 47.5 \\
\hline SB4 1100 Can Baseline + ARP-V SRAT Product Solids & 1.223 & 32.7 & 40.9 & 49.0 \\
\hline
\end{tabular}

\subsection{Impact of “Troublesome” Components on Model Applicability}

One of the secondary objectives of this evaluation was to assess potential issues associated with model applicability and/or individual solubility limits with the introduction of the ARP streams. More specifically, based on the blending strategies, the additions of $\mathrm{TiO}_{2}$ and $\mathrm{SO}_{4}$ from the ARP streams could result in these oxides exceeding some critical value that would give rise to uncertainties or questions associated with the applicability of select models or exceeding individual solubility limits. In Section 6.6, issues associated with $\mathrm{SO}_{4}$ as they relate to assumed $\mathrm{SO}_{4}$ limits in PCCS were discussed. In general, $\mathrm{SO}_{4}$ limits of 0.5 and $0.6 \mathrm{wt} \%$ (in glass) appear to be sufficient to avoid the SB4 - ARP systems from being $\mathrm{SO}_{4}$ limited at the upper WLs.

With respect to model applicability issues, the primary PCCS model of concern was the $T_{L}$ model which was developed over $\mathrm{TiO}_{2}$ concentrations ranging from $0.0-1.8549 \mathrm{wt} \%$ (in glass). Based on the projected blending strategies and $\mathrm{TiO}_{2}$ concentrations, model applicability issues are of minimal concern. More specifically, the maximum $\mathrm{TiO}_{2}$ concentrations in glass are well below the $2 \mathrm{wt} \%$ limit established by Lorier and Jantzen (2003). 
WSRC-TR-2005-00123

Revision 0

\subsection{SUMMARY}

The model-based assessments of nominal Sludge Batch 4 (SB4) compositions suggest that a viable frit candidate does not appear to be a limiting factor as the Closure Business Unit (CBU) considers various tank blending options for SB4 with or without the Actinide Removal Process (ARP) streams. This statement is based solely on the projected operating windows derived from model predictions and does not include experimental assessments of $\mathrm{SO}_{4}$ solubility or melt rate issues. The viable frit candidates covered a range of $\mathrm{Na}_{2} \mathrm{O}$ concentrations (from $8 \%$ to $13 \%$ ) using a "sliding $\mathrm{Na}_{2} \mathrm{O}$ scale" concept (i.e., $1 \%$ increase in $\mathrm{Na}_{2} \mathrm{O}$ being balanced by a $1 \%$ reduction in $\mathrm{SiO}_{2}$ ) which effectively balanced the alkali content of the incoming sludge with that in the frit to maintain and/or increase the projected operating window size while potentially leading to improved melt rate and/or waste loadings. This strategy or approach allows alternative tank blending strategies to be considered and accounted for in an effective manner without wholesale changes to the frit composition.

To assess the impact of the various ARP options on the projected operating windows, the 1100 canister SB4 baseline options served as the technical baseline or reference point for the comparisons. With respect to the various ARP options being considered, the impacts to the projected operating windows were relatively consistent. For those 1100 canister SB4 systems (without ARP) which were $\mathrm{T}_{\mathrm{L}}$-limited, the general impact was an increase in the upper WL which was classified as acceptable resulting in an overall increase in the operating window size. The anticipated negative impact of $\mathrm{TiO}_{2}$ (due to an assumed increase in $\mathrm{T}_{\mathrm{L}}$ which would further reduce the size of the operating window of such systems) was not observed. The hypothesis is that the negative impact was countered or compensated by a positive impact due to the additional $\mathrm{Na}_{2} \mathrm{O}$ from the ARP process. The overall result was a net increase in the size of the operating window for the SB4 1100 canister options which were $\mathrm{T}_{\mathrm{L}}$-limited. This trend was observed for all five ARP options with the only difference being the magnitude of the increase (ranging from a 1\% - 4\% increase) which was strictly based on the specific ARP composition and blending strategy.

Another general observation for all five ARP options was a negative impact with their addition to a 1100 canister system that was initially low viscosity limited or durability limited. For these systems, addition of each ARP stream resulted in a negative impact to the upper WL defining the operating window as a result of the additional $\mathrm{Na}_{2} \mathrm{O}$ introduced which drove both viscosity and durability predictions lower at the same WL. The magnitude of the impact ranged from a $1-2 \%$ reduction for low viscosity limited systems to complete elimination of the operating windows for durability limited systems. The latter situation (i.e., complete elimination of the operating window for a given SB4 blending option with a specified frit) would require a change in frit to compositionally compensate for the ARP addition.

One of the most interesting ARP options was the introduction of the ARP-K case. Model-based predictions and projected $\mathrm{TiO}_{2}$ concentrations, would require an increase in the current $\mathrm{PCCS} \mathrm{TiO} 2$ limit from $1 \mathrm{wt} \%$ to $2 \mathrm{wt} \%$ (if WLs targeting 39\% or greater are desired). With this increase, there appears to be some potential advantages of this ARP stream relative to the other four ARP options. One potential advantage is based on the $\sim 4 \%$ increase in the upper WL defining the projected window for most of the options being considered (which were initially $\mathrm{T}_{\mathrm{L}}$ limited). Although potentially advantageous for some systems, the addition of the ARP-K stream could be devastating to other systems if compositional adjustments are not made (i.e., a frit change). Frits could be selected that are robust to the inclusion of the ARP but they may not be optimized for other properties (e.g., melt rate).

Although ARP-K has potential advantages on the projected operating windows, the other ARP options evaluated should not be dismissed as other criteria (e.g., melt rate and/or CPC processing issues) should be considered prior to pursuing a particular ARP processing scenario. More specifically, based on the assessments performed 
in this report, there are no show-stoppers for any of the ARP options being considered - although some options could require a frit change between a "sludge-only" flowsheet and its "coupled" (sludge plus ARP) counterpart.

Based on the SB4 - ARP blending strategies, the additions of $\mathrm{TiO}_{2}$ and $\mathrm{SO}_{4}$ from the ARP streams could result in these oxides exceeding some critical value that would give rise to uncertainties or questions associated with the applicability of select models or exceeding individual solubility limits. In general, establishing a PCCS $\mathrm{SO}_{4}$ limit of 0.5 or $0.6 \mathrm{wt} \%$ (in glass) appears to be sufficient to avoid the SB4 - ARP systems from being $\mathrm{SO}_{4}$ limited at the upper WLs. With respect to model applicability issues, the primary PCCS model of concern was the $\mathrm{T}_{\mathrm{L}}$ model which was developed over $\mathrm{TiO}_{2}$ concentrations ranging from $0.0-1.8549 \mathrm{wt} \%$ (in glass). Although the ARP- K option would require the $\mathrm{TiO}_{2}$ limit to be raised to $2.0 \mathrm{wt} \%$, maximum $\mathrm{TiO}_{2}$ concentrations in glass are well below the $2 \mathrm{wt} \%$ limit established by Lorier and Jantzen (2003). 
WSRC-TR-2005-00123

Revision 0

\subsection{REFERENCES}

ASTM 2002. Standard Test Methods for Determining Chemical Durability of Nuclear Waste Glasses: The Product Consistency Test (PCT), ASTM C-1285-2002.

Brown KG, CM Jantzen, and G Ritzhaupt. 2001. Relating Liquidus Temperature to Composition for Defense Waste Processing Facility (DWPF) Process Control, WSRC-TR-2001-00520, Westinghouse Savannah River Company, Aiken, South Carolina.

Brown, KG, RL Postles, and TB Edwards, 2002. SME Acceptability Determination for DWPF Process Control, WSRC-TR-95-0364, Revision 4, Westinghouse Savannah River Company, Aiken, South Carolina.

Jantzen, CM, JB Pickett, KG Brown, TB Edwards, and DC Beam. 1995. Process/Product Models for the Defense Waste Processing Facility (DWPF): Part I. Predicting Glass Durability from Composition Using a Thermodynamic Hydration Energy Reaction Model (THERMO), WSRC-TR-93-672, Revision 1, Volume 1, Westinghouse Savannah River Company, Aiken, South Carolina.

Herman, CC. 2005. Sludge Batch 4 Composition Projections with ARP, SRNL-ITS-2005-0036, Revision 0, Westinghouse Savannah River Company, Aiken, South Carolina.

Lilliston, GR. 2005. Development of Elemental Sludge Compositions for Variations of Sludge Batch 4 (SB4), CBU-PIT-2004-00011, Revision 1, Westinghouse Savannah River Company, Aiken, South Carolina.

Lorier, TH and CM Jantzen, 2003. Evaluation of the $\mathbf{T i O}_{2}$ Limit for DWPF Glass, WSRC-TR-2003-00396, Revision 0, Westinghouse Savannah River Company, Aiken, South Carolina.

Peeler, DK and TB Edwards. 2002. Frit Development for Sludge Batch 3, WSRC-TR-2002-00491, Revision 0, Westinghouse Savannah River Company, Aiken, South Carolina.

Peeler, DK and ME Smith. 2004. Investigation to Increase the Overall Waste Throughput in the DWPF Melter, WSRC-RP-2004-00713, Revision 0, Westinghouse Savannah River Company, Aiken, South Carolina.

Peeler, DK. 2004. Sludge Batch 4 and MCU Frit Optimization, Task Technical and QA Plan, WSRC-TR2004-00746, Revision 0, Westinghouse Savannah River Company, Aiken, South Carolina.

Peeler, DK and TB Edwards. 2005. Frit Development Efforts for Sludge Batch 4 (SB4): Model-Based Assessments, WSRC-TR-2005-00103, Revision 0, Westinghouse Savannah River Company, Aiken, South Carolina.

Peeler, DK, CC Herman, and TB Edwards. 2005. The Impact of MCU on the Sludge Batch 4 (SB4) Variability Study, WSRC-TR-2005-00041, Revision 0, Westinghouse Savannah River Company, Aiken, South Carolina.

Shah, HB, GR Lilliston, and JM Gillam. Preliminary Blending, Washing, Additions, Feed and Glass Qualification Strategies for the Combination of Sludge Batch 4 (Tanks 4, 5, 6, 8, and 11) with Sludge Batch 3 as Feed into DWPF, CBU-PIT-2004-00021, Revision 0, Westinghouse Savannah River Company, Aiken, South Carolina. 
Subosits, SG. 2004. Actinide Removal Process Material Balance Calculation with Low Curie Salt Feed. X-CLS-S-00113, Revision 0, Westinghouse Savannah River Company, Aiken, South Carolina.

Washburn, FA. 2004. Sludge Batch 4 and MCU Frit Optimization, Technical Task Request,

HLW/DWPF/TTR-2004-0026, Revision 0, Westinghouse Savannah River Company, Aiken, South Carolina. 
WSRC-TR-2005-00123

Revision 0

\section{APPENDIX A}

\section{Projected SB4 and ARP SRAT Compositions}


Table A.1 - Projected SRAT Products with ARP-A.

\begin{tabular}{|c|c|c|c|c|c|c|c|c|c|c|}
\hline & $\begin{array}{c}\text { SB4 } \\
\text { Baseline }\end{array}$ & $\begin{array}{l}\text { SB4 Min Al, } \\
\text { Na, Mg, Ti; } \\
\text { Max Ce, Fe, } \\
\text { Mg, Ni, U }\end{array}$ & $\begin{array}{c}\text { SB4 Max Al, } \\
\text { Na, Mg, Ti; } \\
\text { Min Ce, Fe, } \\
\text { Mn, Ni, U }\end{array}$ & $\begin{array}{c}\text { SB4 } 1100 \\
\text { Can } \\
\text { Baseline }\end{array}$ & $\begin{array}{c}\text { SB4 1100 } \\
\text { Can 2nd } \\
\text { Transfer, } \\
\text { Baseline }\end{array}$ & $\begin{array}{c}\text { SB4 } 1100 \text { Can } \\
\text { Min Al, Na; Max } \\
\text { Ce, Fe, Mn, U }\end{array}$ & $\begin{array}{c}\text { SB4 } 1100 \\
\text { Can Max Al, } \\
\text { Na; Min Mn, } \\
\text { Ni, U }\end{array}$ & $\begin{array}{c}\text { SB4 } 1100 \\
\text { Can Min } \\
\text { Ce, Mg, Ti }\end{array}$ & $\begin{array}{c}\text { SB4 } \\
1100 \\
\text { Can } \\
\text { Min Fe }\end{array}$ & $\begin{array}{c}\text { SB4 } \\
1100 \\
\text { Can } \\
\text { Max Mg }\end{array}$ \\
\hline $\mathrm{Al}_{2} \mathrm{O}_{3}$ & 30.6 & 25.2 & 45.9 & 22.4 & 24.8 & 19.3 & 31.1 & 26.1 & 28.1 & 21.4 \\
\hline $\mathrm{BaO}$ & 0.185 & 0.223 & 0.081 & 0.160 & 0.167 & 0.175 & 0.107 & 0.183 & 0.156 & 0.161 \\
\hline $\mathrm{CaO}$ & 1.65 & 1.58 & 1.71 & 2.21 & 2.01 & 2.24 & 2.19 & 1.78 & 1.89 & 2.24 \\
\hline $\mathrm{Ce}_{2} \mathrm{O}_{3}$ & 0.190 & 0.187 & 0.189 & 0.207 & 0.200 & 0.208 & 0.205 & 0.191 & 0.193 & 0.207 \\
\hline $\mathrm{Cr}_{2} \mathrm{O}_{3}$ & 0.282 & 0.299 & 0.235 & 0.249 & 0.258 & 0.254 & 0.227 & 0.270 & 0.253 & 0.246 \\
\hline $\mathrm{CuO}$ & 0.078 & 0.084 & 0.057 & 0.083 & 0.081 & 0.086 & 0.071 & 0.079 & 0.074 & 0.082 \\
\hline $\mathrm{Fe}_{2} \mathrm{O}_{3}$ & 20.3 & 21.8 & 15.2 & 25.8 & 23.8 & 27.0 & 22.5 & 22.0 & 22.0 & 26.3 \\
\hline $\mathrm{K}_{2} \mathrm{O}$ & 1.88 & 1.47 & 3.01 & 1.01 & 1.27 & 0.748 & 1.68 & 1.46 & 1.54 & 0.892 \\
\hline $\mathrm{La}_{2} \mathrm{O}_{3}$ & 0.079 & 0.080 & 0.068 & 0.092 & 0.087 & 0.095 & 0.085 & 0.081 & 0.081 & 0.092 \\
\hline $\mathrm{MgO}$ & 0.348 & 0.330 & 0.404 & 1.91 & 1.40 & 2.06 & 1.80 & 0.862 & 1.23 & 2.11 \\
\hline $\mathrm{MnO}$ & 5.12 & 5.90 & 3.30 & 5.82 & 5.55 & 6.24 & 4.78 & 5.51 & 5.36 & 6.08 \\
\hline $\mathrm{Na}_{2} \mathrm{O}$ & 20.4 & 19.8 & 21.8 & 22.4 & 22.3 & 22.1 & 23.2 & 22.1 & 22.5 & 22.3 \\
\hline $\mathrm{PbO}$ & 0.199 & 0.172 & 0.263 & 0.165 & 0.174 & 0.150 & 0.201 & 0.176 & 0.182 & 0.156 \\
\hline $\mathrm{SO}_{4}$ & 1.13 & 1.13 & 1.14 & 1.13 & 1.13 & 1.13 & 1.14 & 1.13 & 1.13 & 1.13 \\
\hline $\mathrm{SiO}_{2}$ & 2.37 & 2.02 & 3.32 & 2.69 & 2.57 & 2.58 & 3.16 & 2.35 & 2.64 & 2.71 \\
\hline $\mathrm{ThO}_{2}$ & 0.039 & 0.030 & 0.065 & 0.034 & 0.036 & 0.030 & 0.048 & 0.035 & 0.040 & 0.034 \\
\hline $\mathrm{TiO}_{2}$ & 0.520 & 0.517 & 0.528 & 0.528 & 0.525 & 0.528 & 0.532 & 0.522 & 0.525 & 0.529 \\
\hline $\mathrm{U}_{3} \mathrm{O}_{8}$ & 8.50 & 11.0 & 1.21 & 9.16 & 8.88 & 10.4 & 5.24 & 9.14 & 7.59 & 9.27 \\
\hline $\mathrm{ZnO}$ & 0.113 & 0.125 & 0.065 & 0.127 & 0.122 & 0.134 & 0.100 & 0.116 & 0.105 & 0.124 \\
\hline $\mathrm{ZrO}_{2}$ & 0.315 & 0.336 & 0.235 & 0.277 & 0.287 & 0.284 & 0.237 & 0.299 & 0.268 & 0.266 \\
\hline
\end{tabular}


Table A.1 - Projected SRAT Products with ARP-A.

\begin{tabular}{|c|c|c|c|c|c|c|c|c|c|c|}
\hline & $\begin{array}{c}\text { SB4 } 1100 \\
\text { Can Max } \\
\text { Ni }\end{array}$ & $\begin{array}{c}\text { SB4 } 1100 \\
\text { Can Max Ti }\end{array}$ & $\begin{array}{l}\text { SB4 } 1200 \\
\text { Can } \\
\text { Baseline }\end{array}$ & $\begin{array}{l}\text { SB4 } 1200 \\
\text { Can 2nd } \\
\text { Transfer } \\
\text { Baseline } \\
\end{array}$ & $\begin{array}{c}\text { SB4 } 1200 \text { Can } \\
\text { Min Al, Na; } \\
\text { Max Ce, Fe, } \\
\text { Mn, U } \\
\end{array}$ & $\begin{array}{c}\text { SB4 } 1200 \text { Can } \\
\text { Max Al, Na; } \\
\text { Min Fe, Mn, } \\
\text { Ni, U }\end{array}$ & $\begin{array}{l}\text { SB4 } 1200 \\
\text { Can Max }\end{array}$ & $\begin{array}{c}\text { SB4 } 1200 \\
\text { Can Min } \\
\text { Ce }\end{array}$ & $\begin{array}{c}\text { SB4 } 1200 \\
\text { Can Min } \\
\text { Mg, Ti }\end{array}$ & $\begin{array}{c}\text { SB4 } 1200 \\
\text { Can Max } \\
\text { Mg, Ti }\end{array}$ \\
\hline $\mathrm{Al}_{2} \mathrm{O}_{3}$ & 22.1 & 28.1 & 23.9 & 25.2 & 20.3 & 32.7 & 22.1 & 28.2 & 26.0 & 29.8 \\
\hline $\mathrm{BaO}$ & 0.198 & 0.114 & 0.164 & 0.168 & 0.183 & 0.103 & 0.198 & 0.156 & 0.182 & 0.110 \\
\hline $\mathrm{CaO}$ & 1.87 & 2.30 & 2.08 & 1.98 & 2.11 & 2.12 & 1.87 & 1.88 & 1.79 & 2.23 \\
\hline $\mathrm{Ce}_{2} \mathrm{O}_{3}$ & 0.195 & 0.209 & 0.202 & 0.198 & 0.203 & 0.201 & 0.194 & 0.192 & 0.191 & 0.206 \\
\hline $\mathrm{Cr}_{2} \mathrm{O}_{3}$ & 0.274 & 0.226 & 0.254 & 0.259 & 0.261 & 0.226 & 0.274 & 0.253 & 0.269 & 0.226 \\
\hline $\mathrm{Fe}_{2} \mathrm{O}_{3}$ & 24.0 & 24.2 & 24.5 & 23.5 & 25.9 & 21.5 & 23.9 & 21.8 & 22.2 & 23.2 \\
\hline $\mathrm{K}_{2} \mathrm{O}$ & 1.11 & 1.40 & 1.18 & 1.32 & 0.878 & 1.83 & 1.12 & 1.56 & 1.44 & 1.56 \\
\hline $\mathrm{La}_{2} \mathrm{O}_{3}$ & 0.086 & 0.090 & 0.089 & 0.086 & 0.091 & 0.083 & 0.086 & 0.080 & 0.082 & 0.087 \\
\hline $\mathrm{MgO}$ & 1.14 & 2.11 & 1.58 & 1.31 & 1.73 & 1.62 & 1.13 & 1.20 & 0.904 & 1.93 \\
\hline $\mathrm{MnO}$ & 5.98 & 5.12 & 5.65 & 5.51 & 6.16 & 4.60 & 5.99 & 5.35 & 5.53 & 4.94 \\
\hline $\mathrm{Na}_{2} \mathrm{O}$ & 21.9 & 23.0 & 22.3 & 22.3 & 22.0 & 23.3 & 21.9 & 22.5 & 22.2 & 23.1 \\
\hline $\mathrm{NiO}$ & 5.98 & 1.51 & 4.08 & 4.42 & 4.89 & 1.43 & 5.99 & 4.24 & 5.46 & 1.48 \\
\hline $\mathrm{PbO}$ & 0.160 & 0.189 & 0.170 & 0.175 & 0.153 & 0.207 & 0.159 & 0.182 & 0.175 & 0.195 \\
\hline $\mathrm{ThO}_{2}$ & 0.030 & 0.045 & 0.035 & 0.036 & 0.029 & 0.050 & 0.029 & 0.040 & 0.035 & 0.046 \\
\hline $\mathrm{TiO}_{2}$ & 0.522 & 0.532 & 0.526 & 0.525 & 0.526 & 0.531 & 0.522 & 0.525 & 0.522 & 0.532 \\
\hline $\mathrm{U}_{3} \mathrm{O}_{8}$ & 10.6 & 6.13 & 8.99 & 8.84 & 10.4 & 4.74 & 10.6 & 7.56 & 9.15 & 5.63 \\
\hline $\mathrm{ZnO}$ & 0.128 & 0.109 & 0.123 & 0.120 & 0.131 & 0.095 & 0.127 & 0.104 & 0.117 & 0.103 \\
\hline $\mathrm{ZrO}_{2}$ & 0.307 & 0.239 & 0.282 & 0.287 & 0.290 & 0.234 & 0.306 & 0.267 & 0.297 & 0.236 \\
\hline
\end{tabular}


Table A.2 - Projected SRAT Products with ARP-E.

\begin{tabular}{|c|c|c|c|c|c|c|c|c|c|c|}
\hline & $\begin{array}{c}\text { SB4 } \\
\text { Baseline }\end{array}$ & $\begin{array}{c}\text { SB4 Min Al, } \\
\text { Na, Mg, Ti; } \\
\text { Max Ce, Fe, } \\
\text { Mg, Ni, U }\end{array}$ & $\begin{array}{c}\text { SB4 Max Al, } \\
\text { Na, Mg, Ti; } \\
\text { Min Ce, Fe, } \\
\text { Mn, Ni, U }\end{array}$ & $\begin{array}{c}\text { SB4 } 1100 \\
\text { Can } \\
\text { Baseline }\end{array}$ & $\begin{array}{c}\text { SB4 1100 } \\
\text { Can 2nd } \\
\text { Transfer, } \\
\text { Baseline }\end{array}$ & $\begin{array}{c}\text { SB4 } 1100 \\
\text { Can Min Al, } \\
\text { Na; Max Ce, } \\
\text { Fe, Mn, U }\end{array}$ & $\begin{array}{c}\text { SB4 } 1100 \\
\text { Can Max Al, } \\
\text { Na; Min Mn, } \\
\text { Ni, U }\end{array}$ & $\begin{array}{c}\text { SB4 } 1100 \\
\text { Can Min Ce, } \\
\text { Mg, Ti }\end{array}$ & $\begin{array}{c}\text { SB4 } \\
1100 \\
\text { Can } \\
\text { Min Fe }\end{array}$ & $\begin{array}{c}\text { SB4 } 1100 \\
\text { Can Max } \\
\text { Mg }\end{array}$ \\
\hline $\mathrm{Al}_{2} \mathrm{O}_{3}$ & 29.6 & 24.4 & 44.1 & 21.7 & 24.0 & 18.8 & 30.0 & 25.3 & 27.1 & 20.8 \\
\hline $\mathrm{BaO}$ & 0.182 & 0.219 & 0.083 & 0.159 & 0.165 & 0.173 & 0.108 & 0.181 & 0.155 & 0.159 \\
\hline $\mathrm{CaO}$ & 1.64 & 1.58 & 1.70 & 2.18 & 1.99 & 2.21 & 2.15 & 1.76 & 1.88 & 2.20 \\
\hline $\mathrm{Ce}_{2} \mathrm{O}_{3}$ & 0.192 & 0.190 & 0.191 & 0.209 & 0.202 & 0.210 & 0.207 & 0.193 & 0.196 & 0.209 \\
\hline $\mathrm{CuO}$ & 0.078 & 0.083 & 0.057 & 0.082 & 0.080 & 0.085 & 0.071 & 0.078 & 0.073 & 0.081 \\
\hline $\mathrm{Fe}_{2} \mathrm{O}_{3}$ & 20.2 & 21.6 & 15.3 & 25.4 & 23.5 & 26.6 & 22.3 & 21.8 & 21.8 & 25.9 \\
\hline $\mathrm{K}_{2} \mathrm{O}$ & 1.80 & 1.41 & 2.88 & 0.967 & 1.22 & 0.720 & 1.60 & 1.40 & 1.47 & 0.857 \\
\hline $\mathrm{La}_{2} \mathrm{O}_{3}$ & 0.080 & 0.081 & 0.070 & 0.093 & 0.088 & 0.095 & 0.086 & 0.082 & 0.082 & 0.093 \\
\hline $\mathrm{MgO}$ & 0.339 & 0.322 & 0.392 & 1.83 & 1.34 & 1.97 & 1.72 & 0.828 & 1.18 & 2.02 \\
\hline $\mathrm{MnO}$ & 5.20 & 5.94 & 3.46 & 5.86 & 5.61 & 6.27 & 4.87 & 5.57 & 5.43 & 6.11 \\
\hline $\mathrm{Na}_{2} \mathrm{O}$ & 21.2 & 20.7 & 22.6 & 23.1 & 23.1 & 22.8 & 23.9 & 22.9 & 23.2 & 23.0 \\
\hline $\mathrm{NiO}$ & 5.61 & 7.39 & 1.29 & 3.59 & 4.20 & 4.18 & 1.48 & 5.35 & 4.11 & 3.66 \\
\hline $\mathrm{SiO}_{2}$ & 2.31 & 1.97 & 3.21 & 2.61 & 2.50 & 2.50 & 3.06 & 2.29 & 2.57 & 2.63 \\
\hline $\mathrm{ThO}_{2}$ & 0.037 & 0.029 & 0.062 & 0.033 & 0.034 & 0.028 & 0.046 & 0.033 & 0.038 & 0.032 \\
\hline $\mathrm{TiO}_{2}$ & 1.17 & 1.17 & 1.18 & 1.18 & 1.18 & 1.18 & 1.19 & 1.18 & 1.18 & 1.18 \\
\hline $\mathrm{U}_{3} \mathrm{O}_{8}$ & 8.33 & 10.8 & 1.38 & 8.96 & 8.69 & 10.1 & 5.22 & 8.94 & 7.46 & 9.06 \\
\hline $\mathrm{ZnO}$ & 0.113 & 0.124 & 0.067 & 0.126 & 0.121 & 0.133 & 0.101 & 0.116 & 0.106 & 0.124 \\
\hline$\overline{\mathrm{ZrO}_{2}}$ & 0.314 & 0.335 & 0.238 & 0.278 & 0.288 & 0.284 & 0.240 & 0.299 & 0.270 & 0.268 \\
\hline
\end{tabular}


Table A.2 - Projected SRAT Products with ARP-E.

\begin{tabular}{|c|c|c|c|c|c|c|c|c|c|c|}
\hline & $\begin{array}{c}\text { SB4 } 1100 \\
\text { Can Max } \\
\text { Ni }\end{array}$ & $\begin{array}{c}\text { SB4 } 1100 \\
\text { Can Max Ti }\end{array}$ & $\begin{array}{l}\text { SB4 } 1200 \text { Can } \\
\text { Baseline }\end{array}$ & $\begin{array}{l}\text { SB4 1200 } \\
\text { Can 2nd } \\
\text { Transfer } \\
\text { Baseline }\end{array}$ & $\begin{array}{c}\text { SB4 1200 } \\
\text { Can Min Al, } \\
\text { Na; Max Ce, } \\
\text { Fe, Mn, U }\end{array}$ & $\begin{array}{c}\text { SB4 } 1200 \\
\text { Can Max Al, } \\
\text { Na; Min Fe, } \\
\text { Mn, Ni, U }\end{array}$ & $\begin{array}{l}\text { SB4 } 1200 \\
\text { Can Max }\end{array}$ & $\begin{array}{c}\text { SB4 } 1200 \\
\text { Can Min Ce }\end{array}$ & $\begin{array}{c}\text { SB4 } \\
1200 \\
\text { Can } \\
\text { Min Mg, } \\
\text { Ti }\end{array}$ & $\begin{array}{c}\text { SB4 1200 } \\
\text { Can Max } \\
\text { Mg, Ti }\end{array}$ \\
\hline $\mathrm{Al}_{2} \mathrm{O}_{3}$ & 21.5 & 27.1 & 23.2 & 24.4 & 19.7 & 31.6 & 21.5 & 27.3 & 25.1 & 28.8 \\
\hline $\mathrm{BaO}$ & 0.195 & 0.114 & 0.162 & 0.166 & 0.180 & 0.105 & 0.195 & 0.154 & 0.180 & 0.110 \\
\hline $\mathrm{CaO}$ & 1.85 & 2.26 & 2.05 & 1.96 & 2.08 & 2.09 & 1.85 & 1.86 & 1.78 & 2.20 \\
\hline $\mathrm{Ce}_{2} \mathrm{O}_{3}$ & 0.197 & 0.211 & 0.204 & 0.201 & 0.205 & 0.203 & 0.197 & 0.195 & 0.194 & 0.208 \\
\hline $\mathrm{CuO}$ & 0.083 & 0.074 & 0.080 & 0.079 & 0.084 & 0.069 & 0.083 & 0.073 & 0.078 & 0.072 \\
\hline $\mathrm{Fe}_{2} \mathrm{O}_{3}$ & 23.7 & 23.9 & 24.2 & 23.2 & 25.6 & 21.4 & 23.7 & 21.7 & 22.0 & 23.0 \\
\hline $\mathrm{K}_{2} \mathrm{O}$ & 1.07 & 1.34 & 1.13 & 1.26 & 0.84 & 1.75 & 1.07 & 1.49 & 1.38 & 1.49 \\
\hline $\mathrm{La}_{2} \mathrm{O}_{3}$ & 0.087 & 0.090 & 0.089 & 0.087 & 0.092 & 0.084 & 0.086 & 0.081 & 0.083 & 0.087 \\
\hline $\mathrm{MgO}$ & 1.09 & 2.02 & 1.52 & 1.26 & 1.66 & 1.56 & 1.08 & 1.15 & 0.868 & 1.85 \\
\hline $\mathrm{MnO}$ & 6.02 & 5.20 & 5.71 & 5.57 & 6.19 & 4.70 & 6.03 & 5.42 & 5.59 & 5.03 \\
\hline $\mathrm{Na}_{2} \mathrm{O}$ & 22.6 & 23.7 & 23.1 & 23.1 & 22.8 & 24.0 & 22.6 & 23.2 & 22.9 & 23.8 \\
\hline $\mathrm{NiO}$ & 5.79 & 1.53 & 3.98 & 4.31 & 4.76 & 1.46 & 5.81 & 4.14 & 5.30 & 1.50 \\
\hline $\mathrm{SiO}_{2}$ & 2.20 & 3.04 & 2.55 & 2.48 & 2.40 & 3.07 & 2.20 & 2.56 & 2.30 & 3.06 \\
\hline $\mathrm{ThO}_{2}$ & 0.028 & 0.043 & 0.033 & 0.034 & 0.028 & 0.047 & 0.028 & 0.038 & 0.033 & 0.044 \\
\hline $\mathrm{TiO}_{2}$ & 1.18 & 1.19 & 1.18 & 1.18 & 1.18 & 1.19 & 1.18 & 1.18 & 1.18 & 1.19 \\
\hline $\mathrm{U}_{3} \mathrm{O}_{8}$ & 10.3 & 6.07 & 8.79 & 8.65 & 10.2 & 4.74 & 10.3 & 7.43 & 8.95 & 5.59 \\
\hline $\mathrm{ZnO}$ & 0.127 & 0.109 & 0.122 & 0.120 & 0.130 & 0.096 & 0.126 & 0.105 & 0.116 & 0.103 \\
\hline $\mathrm{ZrO}_{2}$ & 0.307 & 0.242 & 0.282 & 0.288 & 0.290 & 0.237 & 0.306 & 0.269 & 0.297 & 0.239 \\
\hline
\end{tabular}


Table A.3 - Projected SRAT Products with ARP-K.

\begin{tabular}{|c|c|c|c|c|c|c|c|c|c|c|}
\hline & $\begin{array}{c}\text { SB4 } \\
\text { Baseline }\end{array}$ & $\begin{array}{c}\text { SB4 Min Al, } \\
\text { Na, Mg, Ti; } \\
\text { Max Ce, Fe, } \\
\text { Mg, Ni, U }\end{array}$ & $\begin{array}{c}\text { SB4 Max Al, } \\
\text { Na, Mg, Ti; } \\
\text { Min Ce, Fe, } \\
\text { Mn, Ni, U }\end{array}$ & $\begin{array}{c}\text { SB4 } 1100 \\
\text { Can } \\
\text { Baseline }\end{array}$ & $\begin{array}{l}\text { SB4 1100 } \\
\text { Can 2nd } \\
\text { Transfer, } \\
\text { Baseline }\end{array}$ & $\begin{array}{c}\text { SB4 } 1100 \\
\text { Can Min Al, } \\
\text { Na; Max Ce, } \\
\text { Fe, Mn, U }\end{array}$ & $\begin{array}{c}\text { SB4 } 1100 \\
\text { Can Max Al, } \\
\text { Na; Min Mn, } \\
\text { Ni, U }\end{array}$ & $\begin{array}{l}\text { SB4 1100 } \\
\text { Can Min } \\
\text { Ce, Mg, Ti }\end{array}$ & $\begin{array}{c}\text { SB4 } 1100 \\
\text { Can Min } \\
\text { Fe }\end{array}$ & $\begin{array}{c}\text { SB4 } 1100 \\
\text { Can Max } \\
\text { Mg }\end{array}$ \\
\hline $\mathrm{Al}_{2} \mathrm{O}_{3}$ & 28.8 & 23.8 & 43.0 & 21.2 & 23.4 & 18.3 & 29.2 & 24.7 & 26.4 & 20.2 \\
\hline $\mathrm{BaO}$ & 0.177 & 0.213 & 0.081 & 0.155 & 0.161 & 0.169 & 0.106 & 0.176 & 0.151 & 0.155 \\
\hline $\mathrm{CaO}$ & 1.60 & 1.54 & 1.66 & 2.12 & 1.94 & 2.15 & 2.10 & 1.72 & 1.83 & 2.15 \\
\hline $\mathrm{Ce}_{2} \mathrm{O}_{3}$ & 0.188 & 0.185 & 0.187 & 0.204 & 0.197 & 0.205 & 0.202 & 0.189 & 0.191 & 0.204 \\
\hline $\mathrm{Cr}_{2} \mathrm{O}_{3}$ & 0.269 & 0.285 & 0.225 & 0.239 & 0.247 & 0.243 & 0.218 & 0.258 & 0.242 & 0.236 \\
\hline $\mathrm{CuO}$ & 0.076 & 0.081 & 0.056 & 0.080 & 0.078 & 0.083 & 0.069 & 0.076 & 0.072 & 0.079 \\
\hline $\mathrm{Fe}_{2} \mathrm{O}_{3}$ & 19.6 & 21.1 & 14.9 & 24.7 & 22.9 & 25.9 & 21.8 & 21.3 & 21.2 & 25.2 \\
\hline $\mathrm{K}_{2} \mathrm{O}$ & 1.75 & 1.37 & 2.80 & 0.941 & 1.19 & 0.701 & 1.56 & 1.36 & 1.43 & 0.835 \\
\hline $\mathrm{La}_{2} \mathrm{O}_{3}$ & 0.078 & 0.079 & 0.068 & 0.091 & 0.086 & 0.093 & 0.084 & 0.080 & 0.080 & 0.090 \\
\hline $\mathrm{MgO}$ & 0.330 & 0.313 & 0.382 & 1.77 & 1.30 & 1.92 & 1.67 & 0.805 & 1.15 & 1.96 \\
\hline $\mathrm{MnO}$ & 5.08 & 5.80 & 3.39 & 5.72 & 5.48 & 6.12 & 4.76 & 5.44 & 5.30 & 5.97 \\
\hline $\mathrm{Na}_{2} \mathrm{O}$ & 21.9 & 21.3 & 23.2 & 23.7 & 23.7 & 23.5 & 24.5 & 23.5 & 23.8 & 23.6 \\
\hline $\mathrm{NiO}$ & 5.45 & 7.19 & 1.26 & 3.50 & 4.09 & 4.07 & 1.45 & 5.21 & 4.00 & 3.56 \\
\hline $\mathrm{PbO}$ & 0.193 & 0.168 & 0.252 & 0.161 & 0.170 & 0.148 & 0.195 & 0.172 & 0.177 & 0.154 \\
\hline $\mathrm{SO}_{4}$ & 1.26 & 1.26 & 1.27 & 1.26 & 1.26 & 1.26 & 1.27 & 1.26 & 1.27 & 1.26 \\
\hline $\mathrm{SiO}_{2}$ & 2.25 & 1.92 & 3.13 & 2.54 & 2.43 & 2.44 & 2.97 & 2.23 & 2.50 & 2.56 \\
\hline $\mathrm{ThO}_{2}$ & 0.036 & 0.028 & 0.060 & 0.032 & 0.033 & 0.028 & 0.044 & 0.032 & 0.037 & 0.031 \\
\hline $\mathrm{TiO}_{2}$ & 2.44 & 2.43 & 2.44 & 2.44 & 2.44 & 2.44 & 2.45 & 2.44 & 2.44 & 2.44 \\
\hline $\mathrm{U}_{3} \mathrm{O}_{8}$ & 8.11 & 10.5 & 1.36 & 8.72 & 8.46 & 9.83 & 5.09 & 8.70 & 7.27 & 8.82 \\
\hline $\mathrm{ZnO}$ & 0.110 & 0.121 & 0.066 & 0.123 & 0.118 & 0.130 & 0.098 & 0.113 & 0.103 & 0.121 \\
\hline $\mathrm{ZrO}_{2}$ & 0.307 & 0.326 & 0.232 & 0.272 & 0.281 & 0.278 & 0.235 & 0.292 & 0.263 & 0.262 \\
\hline
\end{tabular}


Table A.3 - Projected SRAT Products with ARP-K.

\begin{tabular}{|c|c|c|c|c|c|c|c|c|c|c|}
\hline & $\begin{array}{c}\text { SB4 } 1100 \\
\text { Can Max } \\
\text { Ni }\end{array}$ & $\begin{array}{c}\text { SB4 } 1100 \\
\text { Can Max Ti }\end{array}$ & $\begin{array}{c}\text { SB4 } 1200 \\
\text { Can Baseline }\end{array}$ & $\begin{array}{c}\text { SB4 } 1200 \\
\text { Can 2nd } \\
\text { Transfer } \\
\text { Baseline } \\
\end{array}$ & $\begin{array}{c}\text { SB4 } 1200 \\
\text { Can Min Al, } \\
\text { Na; Max Ce, } \\
\text { Fe, Mn, U }\end{array}$ & $\begin{array}{c}\text { SB4 } 1200 \\
\text { Can Max Al, } \\
\text { Na; Min Fe, } \\
\text { Mn, Ni, U }\end{array}$ & $\begin{array}{l}\text { SB4 } 1200 \\
\text { Can Max }\end{array}$ & $\begin{array}{c}\text { SB4 } 1200 \\
\text { Can Min } \\
\text { Ce }\end{array}$ & $\begin{array}{c}\text { SB4 } 1200 \\
\text { Can Min } \\
\text { Mg, Ti }\end{array}$ & $\begin{array}{c}\text { SB4 } 1200 \\
\text { Can Max } \\
\text { Mg, Ti }\end{array}$ \\
\hline $\mathrm{Al}_{2} \mathrm{O}_{3}$ & 20.9 & 26.4 & 22.6 & 23.8 & 19.3 & 30.8 & 21.0 & 26.6 & 24.5 & 28.0 \\
\hline $\mathrm{BaO}$ & 0.190 & 0.112 & 0.158 & 0.162 & 0.176 & 0.102 & 0.190 & 0.151 & 0.175 & 0.108 \\
\hline $\mathrm{CaO}$ & 1.81 & 2.21 & 2.00 & 1.91 & 2.02 & 2.04 & 1.80 & 1.81 & 1.73 & 2.14 \\
\hline $\mathrm{Ce}_{2} \mathrm{O}_{3}$ & 0.192 & 0.206 & 0.199 & 0.196 & 0.200 & 0.199 & 0.192 & 0.190 & 0.189 & 0.203 \\
\hline $\mathrm{Cr}_{2} \mathrm{O}_{3}$ & 0.262 & 0.217 & 0.243 & 0.248 & 0.249 & 0.217 & 0.261 & 0.242 & 0.257 & 0.217 \\
\hline $\mathrm{CuO}$ & 0.081 & 0.072 & 0.079 & 0.078 & 0.082 & 0.067 & 0.081 & 0.071 & 0.076 & 0.070 \\
\hline $\mathrm{Fe}_{2} \mathrm{O}_{3}$ & 23.1 & 23.3 & 23.6 & 22.6 & 24.9 & 20.8 & 23.1 & 21.1 & 21.4 & 22.4 \\
\hline $\mathrm{K}_{2} \mathrm{O}$ & 1.04 & 1.30 & 1.10 & 1.23 & 0.822 & 1.70 & 1.04 & 1.45 & 1.34 & 1.45 \\
\hline $\mathrm{La}_{2} \mathrm{O}_{3}$ & 0.085 & 0.088 & 0.087 & 0.085 & 0.089 & 0.082 & 0.084 & 0.079 & 0.081 & 0.085 \\
\hline $\mathrm{MgO}$ & 1.06 & 1.96 & 1.47 & 1.22 & 1.61 & 1.51 & 1.05 & 1.12 & 0.844 & 1.79 \\
\hline $\mathrm{MnO}$ & 5.88 & 5.08 & 5.57 & 5.44 & 6.04 & 4.59 & 5.88 & 5.29 & 5.46 & 4.91 \\
\hline $\mathrm{Na}_{2} \mathrm{O}$ & 23.3 & 24.3 & 23.7 & 23.7 & 23.4 & 24.5 & 23.3 & 23.8 & 23.5 & 24.4 \\
\hline $\mathrm{NiO}$ & 5.63 & 1.50 & 3.88 & 4.19 & 4.63 & 1.42 & 5.65 & 4.03 & 5.15 & 1.47 \\
\hline $\mathrm{PbO}$ & 0.157 & 0.184 & 0.166 & 0.171 & 0.150 & 0.201 & 0.156 & 0.177 & 0.171 & 0.189 \\
\hline $\mathrm{SO}_{4}$ & 1.26 & 1.27 & 1.26 & 1.26 & 1.26 & 1.27 & 1.26 & 1.27 & 1.26 & 1.27 \\
\hline $\mathrm{SiO}_{2}$ & 2.14 & 2.96 & 2.48 & 2.42 & 2.34 & 2.99 & 2.14 & 2.50 & 2.24 & 2.97 \\
\hline $\mathrm{ThO}_{2}$ & 0.027 & 0.041 & 0.032 & 0.033 & 0.027 & 0.046 & 0.027 & 0.037 & 0.032 & 0.043 \\
\hline $\mathrm{TiO}_{2}$ & 2.44 & 2.45 & 2.44 & 2.44 & 2.44 & 2.45 & 2.44 & 2.44 & 2.44 & 2.45 \\
\hline $\mathrm{U}_{3} \mathrm{O}_{8}$ & 10.0 & 5.92 & 8.56 & 8.42 & 9.90 & 4.63 & 10.0 & 7.24 & 8.71 & 5.45 \\
\hline $\mathrm{ZnO}$ & 0.124 & 0.106 & 0.119 & 0.117 & 0.127 & 0.093 & 0.123 & 0.102 & 0.113 & 0.101 \\
\hline $\mathrm{ZrO}_{2}$ & 0.300 & 0.237 & 0.276 & 0.281 & 0.283 & 0.232 & 0.299 & 0.262 & 0.290 & 0.233 \\
\hline
\end{tabular}


Table A.4 - Projected SRAT Products with ARP-M.

\begin{tabular}{|c|c|c|c|c|c|c|c|c|c|c|}
\hline & $\begin{array}{c}\text { SB4 } \\
\text { Baseline }\end{array}$ & $\begin{array}{c}\text { SB4 Min Al, } \\
\text { Na, Mg, Ti; } \\
\text { Max Ce, Fe, } \\
\text { Mg, Ni, U }\end{array}$ & $\begin{array}{c}\text { SB4 Max Al, } \\
\text { Na, Mg, Ti; } \\
\text { Min Ce, Fe, } \\
\text { Mn, Ni, U }\end{array}$ & $\begin{array}{c}\text { SB4 } \\
1100 \\
\text { Can } \\
\text { Baseline }\end{array}$ & $\begin{array}{c}\text { SB4 1100 } \\
\text { Can 2nd } \\
\text { Transfer, } \\
\text { Baseline }\end{array}$ & $\begin{array}{c}\text { SB4 } 1100 \text { Can } \\
\text { Min Al, Na; } \\
\text { Max Ce, Fe, } \\
\text { Mn, U }\end{array}$ & $\begin{array}{c}\text { SB4 } 1100 \\
\text { Can Max Al, } \\
\text { Na; Min Mn, } \\
\text { Ni, U }\end{array}$ & $\begin{array}{l}\text { SB4 1100 } \\
\text { Can Min } \\
\text { Ce, Mg, Ti }\end{array}$ & $\begin{array}{c}\text { SB4 } \\
1100 \\
\text { Can } \\
\text { Min Fe }\end{array}$ & $\begin{array}{c}\text { SB4 1100 } \\
\text { Can Max } \\
\text { Mg }\end{array}$ \\
\hline $\mathrm{Al}_{2} \mathrm{O}_{3}$ & 30.0 & 24.8 & 44.8 & 22.1 & 24.4 & 19.1 & 30.4 & 25.7 & 27.5 & 21.1 \\
\hline $\mathrm{BaO}$ & 0.186 & 0.223 & 0.085 & 0.162 & 0.168 & 0.177 & 0.111 & 0.184 & 0.158 & 0.162 \\
\hline $\mathrm{CaO}$ & 1.67 & 1.61 & 1.73 & 2.22 & 2.03 & 2.25 & 2.20 & 1.80 & 1.91 & 2.25 \\
\hline $\mathrm{Ce}_{2} \mathrm{O}_{3}$ & 0.197 & 0.195 & 0.196 & 0.214 & 0.207 & 0.215 & 0.212 & 0.198 & 0.201 & 0.214 \\
\hline $\mathrm{Cr}_{2} \mathrm{O}_{3}$ & 0.282 & 0.298 & 0.236 & 0.250 & 0.258 & 0.254 & 0.228 & 0.270 & 0.253 & 0.247 \\
\hline $\mathrm{CuO}$ & 0.079 & 0.085 & 0.059 & 0.084 & 0.082 & 0.087 & 0.072 & 0.080 & 0.075 & 0.083 \\
\hline $\mathrm{Fe}_{2} \mathrm{O}_{3}$ & 20.6 & 22.1 & 15.7 & 25.9 & 24.0 & 27.2 & 22.8 & 22.3 & 22.3 & 26.4 \\
\hline $\mathrm{K}_{2} \mathrm{O}$ & 1.82 & 1.43 & 2.91 & 0.981 & 1.24 & 0.73 & 1.63 & 1.42 & 1.49 & 0.870 \\
\hline $\mathrm{La}_{2} \mathrm{O}_{3}$ & 0.082 & 0.083 & 0.072 & 0.095 & 0.090 & 0.097 & 0.088 & 0.084 & 0.084 & 0.095 \\
\hline $\mathrm{MgO}$ & 0.345 & 0.327 & 0.399 & 1.85 & 1.36 & 2.00 & 1.74 & 0.841 & 1.20 & 2.04 \\
\hline $\mathrm{MnO}$ & 5.33 & 6.09 & 3.57 & 6.00 & 5.75 & 6.41 & 5.00 & 5.70 & 5.57 & 6.26 \\
\hline $\mathrm{Na}_{2} \mathrm{O}$ & 21.0 & 20.4 & 22.4 & 22.9 & 22.9 & 22.6 & 23.7 & 22.7 & 23.0 & 22.8 \\
\hline $\mathrm{NiO}$ & 5.70 & 7.50 & 1.33 & 3.66 & 4.28 & 4.25 & 1.52 & 5.44 & 4.18 & 3.73 \\
\hline $\mathrm{PbO}$ & 0.202 & 0.176 & 0.264 & 0.169 & 0.178 & 0.155 & 0.204 & 0.180 & 0.186 & 0.161 \\
\hline $\mathrm{SO}_{4}$ & 1.21 & 1.21 & 1.22 & 1.21 & 1.21 & 1.21 & 1.22 & 1.21 & 1.21 & 1.21 \\
\hline $\mathrm{SiO}_{2}$ & 2.35 & 2.01 & 3.27 & 2.66 & 2.54 & 2.55 & 3.10 & 2.33 & 2.61 & 2.68 \\
\hline $\mathrm{ThO}_{2}$ & 0.038 & 0.029 & 0.063 & 0.033 & 0.034 & 0.029 & 0.046 & 0.034 & 0.039 & 0.032 \\
\hline $\mathrm{TiO}_{2}$ & 0.012 & 0.009 & 0.020 & 0.020 & 0.017 & 0.020 & 0.024 & 0.014 & 0.018 & 0.021 \\
\hline $\mathrm{U}_{3} \mathrm{O}_{8}$ & 8.48 & 10.9 & 1.44 & 9.12 & 8.85 & 10.3 & 5.33 & 9.10 & 7.60 & 9.22 \\
\hline $\mathrm{ZnO}$ & 0.115 & 0.127 & 0.069 & 0.129 & 0.124 & 0.136 & 0.103 & 0.119 & 0.108 & 0.126 \\
\hline $\mathrm{ZrO}_{2}$ & 0.321 & 0.342 & 0.244 & 0.285 & 0.294 & 0.291 & 0.246 & 0.306 & 0.276 & 0.274 \\
\hline
\end{tabular}


Table A.4 - Projected SRAT Products with ARP-M.

\begin{tabular}{|c|c|c|c|c|c|c|c|c|c|c|}
\hline & $\begin{array}{c}\text { SB4 } 1100 \\
\text { Can Max } \\
\text { Ni }\end{array}$ & $\begin{array}{c}\text { SB4 1100 } \\
\text { Can Max Ti }\end{array}$ & $\begin{array}{c}\text { SB4 } 1200 \\
\text { Can Baseline }\end{array}$ & $\begin{array}{c}\text { SB4 } \\
1200 \\
\text { Can 2nd } \\
\text { Transfer } \\
\text { Baseline }\end{array}$ & $\begin{array}{c}\text { SB4 } 1200 \\
\text { Can Min } \\
\text { Al, Na; } \\
\text { Max Ce, } \\
\text { Fe, Mn, U }\end{array}$ & $\begin{array}{c}\text { SB4 } 1200 \text { Can } \\
\text { Max Al, Na; } \\
\text { Min Fe, Mn, } \\
\text { Ni, U }\end{array}$ & $\begin{array}{l}\text { SB4 1200 } \\
\text { Can Max }\end{array}$ & $\begin{array}{c}\text { SB4 } 1200 \\
\text { Can Min } \\
\text { Ce }\end{array}$ & $\begin{array}{c}\text { SB4 } \\
1200 \\
\text { Can } \\
\text { Min Mg, } \\
\text { Ti }\end{array}$ & $\begin{array}{c}\text { SB4 } 1200 \\
\text { Can Max } \\
\text { Mg, Ti }\end{array}$ \\
\hline $\mathrm{Al}_{2} \mathrm{O}_{3}$ & 21.8 & 27.5 & 23.6 & 24.8 & 20.1 & 32.1 & 21.8 & 27.7 & 25.5 & 29.2 \\
\hline $\mathrm{BaO}$ & 0.199 & 0.117 & 0.166 & 0.169 & 0.184 & 0.107 & 0.198 & 0.158 & 0.183 & 0.113 \\
\hline $\mathrm{CaO}$ & 1.89 & 2.31 & 2.09 & 1.99 & 2.12 & 2.13 & 1.89 & 1.90 & 1.81 & 2.24 \\
\hline $\mathrm{Ce}_{2} \mathrm{O}_{3}$ & 0.202 & 0.216 & 0.209 & 0.206 & 0.210 & 0.208 & 0.201 & 0.200 & 0.198 & 0.213 \\
\hline $\mathrm{Cr}_{2} \mathrm{O}_{3}$ & 0.274 & 0.227 & 0.255 & 0.259 & 0.261 & 0.228 & 0.274 & 0.253 & 0.269 & 0.227 \\
\hline $\mathrm{CuO}$ & 0.085 & 0.076 & 0.082 & 0.081 & 0.086 & 0.070 & 0.084 & 0.075 & 0.080 & 0.073 \\
\hline $\mathrm{Fe}_{2} \mathrm{O}_{3}$ & 24.2 & 24.4 & 24.7 & 23.7 & 26.1 & 21.8 & 24.1 & 22.1 & 22.4 & 23.5 \\
\hline $\mathrm{K}_{2} \mathrm{O}$ & 1.08 & 1.36 & 1.15 & 1.28 & 0.856 & 1.78 & 1.09 & 1.51 & 1.40 & 1.51 \\
\hline $\mathrm{La}_{2} \mathrm{O}_{3}$ & 0.089 & 0.092 & 0.091 & 0.089 & 0.094 & 0.086 & 0.088 & 0.083 & 0.085 & 0.090 \\
\hline $\mathrm{MgO}$ & 1.11 & 2.04 & 1.54 & 1.28 & 1.68 & 1.58 & 1.10 & 1.17 & 0.881 & 1.87 \\
\hline $\mathrm{MnO}$ & 6.17 & 5.34 & 5.85 & 5.71 & 6.34 & 4.83 & 6.17 & 5.56 & 5.73 & 5.16 \\
\hline $\mathrm{Na}_{2} \mathrm{O}$ & 22.4 & 23.6 & 22.9 & 22.9 & 22.6 & 23.8 & 22.4 & 23.0 & 22.7 & 23.6 \\
\hline $\mathrm{NiO}$ & 5.89 & 1.57 & 4.06 & 4.38 & 4.84 & 1.49 & 5.90 & 4.21 & 5.39 & 1.54 \\
\hline $\mathrm{PbO}$ & 0.164 & 0.193 & 0.175 & 0.179 & 0.158 & 0.210 & 0.164 & 0.186 & 0.180 & 0.198 \\
\hline $\mathrm{SO}_{4}$ & 1.21 & 1.22 & 1.21 & 1.21 & 1.21 & 1.22 & 1.21 & 1.21 & 1.21 & 1.22 \\
\hline $\mathrm{SiO}_{2}$ & 2.23 & 3.09 & 2.59 & 2.53 & 2.44 & 3.12 & 2.24 & 2.61 & 2.34 & 3.11 \\
\hline $\mathrm{ThO}_{2}$ & 0.029 & 0.043 & 0.034 & 0.034 & 0.028 & 0.048 & 0.028 & 0.039 & 0.034 & 0.045 \\
\hline $\mathrm{TiO}_{2}$ & 0.014 & 0.025 & 0.019 & 0.017 & 0.018 & 0.023 & 0.014 & 0.018 & 0.014 & 0.024 \\
\hline $\mathrm{U}_{3} \mathrm{O}_{8}$ & 10.5 & 6.20 & 8.95 & 8.81 & 10.4 & 4.85 & 10.5 & 7.57 & 9.11 & 5.71 \\
\hline $\mathrm{ZnO}$ & 0.130 & 0.111 & 0.125 & 0.122 & 0.133 & 0.098 & 0.129 & 0.107 & 0.119 & 0.106 \\
\hline $\mathrm{ZrO}_{2}$ & 0.314 & 0.248 & 0.289 & 0.294 & 0.297 & 0.243 & 0.313 & 0.275 & 0.304 & 0.245 \\
\hline
\end{tabular}


Table A.5 - Projected SRAT Products with ARP-V.

\begin{tabular}{|c|c|c|c|c|c|c|c|c|c|c|}
\hline & $\begin{array}{c}\text { SB4 } \\
\text { Baseline }\end{array}$ & $\begin{array}{c}\text { SB4 Min Al, } \\
\text { Na, Mg, Ti; } \\
\text { Max Ce, Fe, } \\
\text { Mg, Ni, U }\end{array}$ & $\begin{array}{c}\text { SB4 Max Al, } \\
\text { Na, Mg, Ti; } \\
\text { Min Ce, Fe, } \\
\text { Mn, Ni, U }\end{array}$ & $\begin{array}{c}\text { SB4 } \\
1100 \\
\text { Can } \\
\text { Baseline }\end{array}$ & $\begin{array}{c}\text { SB4 1100 } \\
\text { Can 2nd } \\
\text { Transfer, } \\
\text { Baseline }\end{array}$ & $\begin{array}{c}\text { SB4 } 1100 \\
\text { Can Min Al, } \\
\text { Na; Max Ce, } \\
\text { Fe, Mn, U }\end{array}$ & $\begin{array}{c}\text { SB4 1100 } \\
\text { Can Max Al, } \\
\text { Na; Min Mn, } \\
\text { Ni, U }\end{array}$ & $\begin{array}{c}\text { SB4 } 1100 \\
\text { Can Min } \\
\text { Ce, Mg, Ti }\end{array}$ & $\begin{array}{c}\text { SB4 } \\
1100 \\
\text { Can } \\
\text { Min Fe }\end{array}$ & $\begin{array}{c}\text { SB4 } 1100 \\
\text { Can Max } \\
\text { Mg }\end{array}$ \\
\hline $\mathrm{Al}_{2} \mathrm{O}_{3}$ & 29.4 & 24.3 & 43.9 & 21.5 & 23.8 & 18.6 & 29.8 & 25.1 & 26.9 & 20.6 \\
\hline $\mathrm{BaO}$ & 0.180 & 0.216 & 0.081 & 0.157 & 0.163 & 0.171 & 0.106 & 0.178 & 0.152 & 0.157 \\
\hline $\mathrm{CaO}$ & 1.61 & 1.55 & 1.67 & 2.15 & 1.96 & 2.18 & 2.13 & 1.74 & 1.85 & 2.18 \\
\hline $\mathrm{Ce}_{2} \mathrm{O}_{3}$ & 0.188 & 0.186 & 0.188 & 0.205 & 0.198 & 0.206 & 0.203 & 0.189 & 0.192 & 0.205 \\
\hline $\mathrm{Cr}_{2} \mathrm{O}_{3}$ & 0.273 & 0.289 & 0.228 & 0.242 & 0.250 & 0.246 & 0.220 & 0.262 & 0.246 & 0.239 \\
\hline $\mathrm{CuO}$ & 0.077 & 0.082 & 0.056 & 0.081 & 0.079 & 0.084 & 0.070 & 0.077 & 0.072 & 0.080 \\
\hline $\mathrm{Fe}_{2} \mathrm{O}_{3}$ & 19.8 & 21.3 & 15.0 & 25.1 & 23.2 & 26.3 & 22.0 & 21.5 & 21.5 & 25.5 \\
\hline $\mathrm{K}_{2} \mathrm{O}$ & 1.79 & 1.40 & 2.86 & 0.962 & 1.22 & 0.716 & 1.60 & 1.39 & 1.47 & 0.853 \\
\hline $\mathrm{La}_{2} \mathrm{O}_{3}$ & 0.078 & 0.080 & 0.068 & 0.091 & 0.086 & 0.093 & 0.085 & 0.081 & 0.080 & 0.091 \\
\hline $\mathrm{MgO}$ & 0.335 & 0.318 & 0.389 & 1.82 & 1.33 & 1.96 & 1.71 & 0.823 & 1.17 & 2.01 \\
\hline $\mathrm{MnO}$ & 5.09 & 5.83 & 3.36 & 5.75 & 5.50 & 6.15 & 4.77 & 5.46 & 5.32 & 6.00 \\
\hline $\mathrm{Na}_{2} \mathrm{O}$ & 21.4 & 20.9 & 22.8 & 23.3 & 23.3 & 23.0 & 24.1 & 23.1 & 23.4 & 23.2 \\
\hline $\mathrm{NiO}$ & 5.56 & 7.33 & 1.26 & 3.55 & 4.16 & 4.13 & 1.45 & 5.31 & 4.06 & 3.62 \\
\hline $\mathrm{PbO}$ & 0.195 & 0.169 & 0.255 & 0.163 & 0.171 & 0.149 & 0.197 & 0.173 & 0.179 & 0.155 \\
\hline $\mathrm{SO}_{4}$ & 1.22 & 1.22 & 1.23 & 1.22 & 1.22 & 1.22 & 1.23 & 1.22 & 1.22 & 1.22 \\
\hline $\mathrm{SiO}_{2}$ & 2.29 & 1.95 & 3.19 & 2.59 & 2.47 & 2.48 & 3.03 & 2.27 & 2.54 & 2.61 \\
\hline $\mathrm{ThO}_{2}$ & 0.037 & 0.029 & 0.062 & 0.032 & 0.034 & 0.028 & 0.046 & 0.033 & 0.038 & 0.032 \\
\hline $\mathrm{TiO}_{2}$ & 1.84 & 1.84 & 1.85 & 1.85 & 1.85 & 1.85 & 1.85 & 1.84 & 1.85 & 1.85 \\
\hline $\mathrm{U}_{3} \mathrm{O}_{8}$ & 8.23 & 10.6 & 1.31 & 8.86 & 8.59 & 9.99 & 5.14 & 8.84 & 7.37 & 8.96 \\
\hline $\mathrm{ZnO}$ & 0.111 & 0.122 & 0.066 & 0.125 & 0.119 & 0.131 & 0.099 & 0.114 & 0.104 & 0.122 \\
\hline $\mathrm{ZrO}_{2}$ & 0.309 & 0.329 & 0.233 & 0.273 & 0.283 & 0.279 & 0.236 & 0.294 & 0.265 & 0.263 \\
\hline
\end{tabular}


Table A.5 - Projected SRAT Products with ARP-V.

\begin{tabular}{|c|c|c|c|c|c|c|c|c|c|c|}
\hline & $\begin{array}{c}\text { SB4 } 1100 \\
\text { Can Max } \\
\text { Ni }\end{array}$ & $\begin{array}{c}\text { SB4 1100 } \\
\text { Can Max Ti }\end{array}$ & $\begin{array}{c}\text { SB4 1200 } \\
\text { Can Baseline }\end{array}$ & $\begin{array}{c}\text { SB4 } \\
1200 \\
\text { Can 2nd } \\
\text { Transfer } \\
\text { Baseline } \\
\end{array}$ & $\begin{array}{c}\text { SB4 } 1200 \\
\text { Can Min } \\
\text { Al, Na; } \\
\text { Max Ce, } \\
\text { Fe, Mn, U }\end{array}$ & $\begin{array}{c}\text { SB4 } 1200 \\
\text { Can Max Al, } \\
\text { Na; Min Fe, } \\
\text { Mn, Ni, U }\end{array}$ & $\begin{array}{l}\text { SB4 } 1200 \\
\text { Can Max }\end{array}$ & $\begin{array}{c}\text { SB4 } 1200 \\
\text { Can Min } \\
\text { Ce }\end{array}$ & $\begin{array}{c}\text { SB4 } \\
1200 \\
\text { Can } \\
\text { Min } \\
\text { Mg, Ti } \\
\end{array}$ & $\begin{array}{c}\text { SB4 } 1200 \\
\text { Can Max } \\
\text { Mg, Ti }\end{array}$ \\
\hline $\mathrm{Al}_{2} \mathrm{O}_{3}$ & 21.3 & 26.9 & 23.0 & 24.2 & 19.6 & 31.4 & 21.3 & 27.1 & 25.0 & 28.6 \\
\hline $\mathrm{BaO}$ & 0.192 & 0.112 & 0.160 & 0.163 & 0.178 & 0.103 & 0.192 & 0.152 & 0.177 & 0.108 \\
\hline $\mathrm{CaO}$ & 1.83 & 2.24 & 2.03 & 1.93 & 2.05 & 2.06 & 1.82 & 1.83 & 1.75 & 2.17 \\
\hline $\mathrm{Ce}_{2} \mathrm{O}_{3}$ & 0.193 & 0.207 & 0.200 & 0.197 & 0.201 & 0.200 & 0.193 & 0.191 & 0.190 & 0.204 \\
\hline $\mathrm{Cr}_{2} \mathrm{O}_{3}$ & 0.266 & 0.220 & 0.247 & 0.251 & 0.253 & 0.220 & 0.265 & 0.246 & 0.261 & 0.220 \\
\hline $\mathrm{CuO}$ & 0.082 & 0.073 & 0.079 & 0.078 & 0.083 & 0.068 & 0.082 & 0.072 & 0.077 & 0.071 \\
\hline $\mathrm{Fe}_{2} \mathrm{O}_{3}$ & 23.4 & 23.6 & 23.9 & 22.9 & 25.2 & 21.1 & 23.3 & 21.3 & 21.6 & 22.7 \\
\hline $\mathrm{K}_{2} \mathrm{O}$ & 1.06 & 1.33 & 1.12 & 1.26 & 0.84 & 1.74 & 1.07 & 1.48 & 1.37 & 1.48 \\
\hline $\mathrm{La}_{2} \mathrm{O}_{3}$ & 0.085 & 0.089 & 0.088 & 0.085 & 0.090 & 0.082 & 0.085 & 0.080 & 0.081 & 0.086 \\
\hline $\mathrm{MgO}$ & 1.08 & 2.00 & 1.51 & 1.25 & 1.65 & 1.55 & 1.076 & 1.142 & 0.863 & 1.838 \\
\hline $\mathrm{MnO}$ & 5.91 & 5.10 & 5.60 & 5.46 & 6.08 & 4.59 & 5.92 & 5.31 & 5.48 & 4.92 \\
\hline $\mathrm{Na}_{2} \mathrm{O}$ & 22.8 & 23.9 & 23.3 & 23.3 & 23.0 & 24.1 & 22.8 & 23.4 & 23.1 & 24.0 \\
\hline $\mathrm{NiO}$ & 5.74 & 1.50 & 3.94 & 4.26 & 4.71 & 1.42 & 5.76 & 4.10 & 5.25 & 1.47 \\
\hline $\mathrm{PbO}$ & 0.158 & 0.185 & 0.168 & 0.172 & 0.151 & 0.203 & 0.157 & 0.179 & 0.172 & 0.191 \\
\hline $\mathrm{SO}_{4}$ & 1.22 & 1.23 & 1.22 & 1.22 & 1.22 & 1.23 & 1.22 & 1.22 & 1.22 & 1.23 \\
\hline $\mathrm{SiO}_{2}$ & 2.17 & 3.01 & 2.52 & 2.46 & 2.38 & 3.04 & 2.17 & 2.54 & 2.28 & 3.03 \\
\hline $\mathrm{ThO}_{2}$ & 0.028 & 0.042 & 0.033 & 0.034 & 0.028 & 0.047 & 0.028 & 0.038 & 0.033 & 0.044 \\
\hline $\mathrm{TiO}_{2}$ & 1.84 & 1.85 & 1.85 & 1.85 & 1.85 & 1.85 & 1.84 & 1.85 & 1.84 & 1.85 \\
\hline $\mathrm{U}_{3} \mathrm{O}_{8}$ & 10.2 & 5.98 & 8.69 & 8.55 & 10.1 & 4.66 & 10.21 & 7.34 & 8.85 & 5.50 \\
\hline $\mathrm{ZnO}$ & 0.125 & 0.107 & 0.120 & 0.118 & 0.128 & 0.094 & 0.124 & 0.103 & 0.114 & 0.101 \\
\hline $\mathrm{ZrO}_{2}$ & 0.302 & 0.238 & 0.277 & 0.283 & 0.285 & 0.233 & 0.301 & 0.264 & 0.292 & 0.234 \\
\hline
\end{tabular}


WSRC-TR-2005-00123

Revision 0

\section{APPENDIX B}

\section{Results of MAR Assessments for SB4 Options}


Table B.1. MAR Results and Various Predicted Properties for the Nominal SB4 Blending Options.

\begin{tabular}{|c|c|c|c|c|c|c|c|c|c|c|c|}
\hline Type & $\begin{array}{c}\text { Frit } \\
\text { ID }\end{array}$ & $\begin{array}{l}\text { Min } \\
\text { WL }\end{array}$ & $\begin{array}{l}\text { Max } \\
\text { WL }\end{array}$ & $\begin{array}{c}\text { Limited } \\
\text { Below By }\end{array}$ & $\begin{array}{c}\text { Limited } \\
\text { Above By }\end{array}$ & $\begin{array}{c}\text { Del Gp } \\
\text { (min) }\end{array}$ & $\begin{array}{c}\text { Visc } \\
\text { (min) }\end{array}$ & $\begin{array}{c}\text { TL } \\
\text { (min) }\end{array}$ & $\begin{array}{c}\text { Del Gp } \\
\text { (max) }\end{array}$ & Visc (max) & TL (max) \\
\hline SB4 Only Baseline & 320 & 25 & 40 & & $\mathrm{TL}$ & -11.6951 & 50.37 & 790.7 & -10.8755 & 66.81 & 1000.1 \\
\hline SB4 Only Baseline & 417 & 25 & 39 & & $\mathrm{TL}$ & -11.0022 & 59.3 & 801.9 & -10.3665 & 76.71 & 998.2 \\
\hline SB4 Only Baseline & 418 & 33 & 36 & hvisc & $\mathrm{TL}$ & -8.7817 & 94.1 & 956 & -8.7286 & 99.65 & 994.1 \\
\hline SB4 Only Baseline & 425 & 25 & 38 & & TL & -10.3092 & 69.48 & 813.5 & -9.839 & 87.75 & 996.6 \\
\hline SB4 Only Baseline & 426 & 25 & 37 & & $\mathrm{TL}$ & -9.6162 & 81.04 & 825.5 & -9.2931 & 100.03 & 995.2 \\
\hline SB4 Only Baseline & 431 & 25 & 40 & & $\mathrm{TL}$ & -12.3881 & 43.6 & 779.8 & -11.4299 & 57.97 & 990.6 \\
\hline SB4 Only Baseline & 441 & 30 & 42 & Del Gp & $\mathrm{TL}$ & -13.3623 & 30.72 & 837.9 & -12.3739 & 39.66 & 995.7 \\
\hline SB4 Only Max Al, Na, Mg, Ti; Min Ce, Fe, Mn, Ni, U & 320 & 25 & 60 & & & -10.7009 & 90.55 & 721.4 & -7.3962 & 95.19 & 971.9 \\
\hline SB4 Only Max Al, Na, Mg, Ti; Min Ce, Fe, Mn, Ni, U & 417 & . & . & & & . & . & . & . & . & . \\
\hline SB4 Only Max Al, Na, Mg, Ti; Min Ce, Fe, Mn, Ni, U & 418 & . & . & & & . & . & . & . & . & . \\
\hline SB4 Only Max Al, Na, Mg, Ti; Min Ce, Fe, Mn, Ni, U & 425 & . & . & & & . & . & . & . & . & . \\
\hline SB4 Only Max Al, Na, Mg, Ti; Min Ce, Fe, Mn, Ni, U & 426 & . & . & & & . & . & . & . & . & . \\
\hline SB4 Only Max Al, Na, Mg, Ti; Min Ce, Fe, Mn, Ni, U & 431 & 25 & 60 & & & -11.3938 & 78.95 & 713.5 & -7.7658 & 83.64 & 968.9 \\
\hline SB4 Only Max Al, Na, Mg, Ti; Min Ce, Fe, Mn, Ni, U & 441 & 25 & 60 & & & -12.7798 & 59.3 & 698.2 & -8.505 & 63.89 & 962.8 \\
\hline SB4 Only Min Al, Na, Mg, Ti; Max Ce, Fe, Mg, Ni, U & 320 & 25 & 35 & & $\mathrm{TL}$ & -12.0464 & 47.53 & 817.8 & -11.6404 & 60.27 & 984.8 \\
\hline SB4 Only Min Al, Na, Mg, Ti; Max Ce, Fe, Mg, Ni, U & 417 & 25 & 35 & & $\mathrm{TL}$ & -11.3534 & 54.8 & 830.5 & -11.0398 & 69.32 & 997.1 \\
\hline SB4 Only Min Al, Na, Mg, Ti; Max Ce, Fe, Mg, Ni, U & 418 & 27 & 32 & hvisc & $\mathrm{TL}$ & -9.2672 & 88.53 & 907.4 & -9.249 & 99.03 & 990.6 \\
\hline SB4 Only Min Al, Na, Mg, Ti; Max Ce, Fe, Mg, Ni, U & 425 & 25 & 34 & & $\mathrm{TL}$ & -10.6604 & 64.61 & 843.6 & -10.4614 & 79.42 & 994.7 \\
\hline SB4 Only Min Al, Na, Mg, Ti; Max Ce, Fe, Mg, Ni, U & 426 & 25 & 33 & & TL & -9.9674 & 75.81 & 857.2 & -9.8644 & 90.67 & 992.5 \\
\hline SB4 Only Min Al, Na, Mg, Ti; Max Ce, Fe, Mg, Ni, U & 431 & 25 & 36 & & TL & -12.7394 & 39.94 & 805.6 & -12.1912 & 52.21 & 987.9 \\
\hline SB4 Only Min Al, Na, Mg, Ti; Max Ce, Fe, Mg, Ni, U & 441 & 36 & 38 & Del Gp & $\overline{T L}$ & -13.3739 & 27.72 & 965 & -13.2373 & 29.43 & 994.7 \\
\hline 1100 Can Baseline & 320 & 25 & 44 & & lvisc & -12.7645 & 24.51 & 741.7 & -12.5389 & 51.08 & 989.7 \\
\hline 1100 Can Baseline & 417 & 25 & 45 & & $\mathrm{TL}$ & -12.0715 & 27.03 & 752.8 & -12.0189 & 58.85 & 1009.7 \\
\hline 1100 Can Baseline & 418 & 25 & 42 & & $\mathrm{TL}$ & -10.419 & 47.81 & 788.4 & -9.9925 & 88.04 & 1008.2 \\
\hline 1100 Can Baseline & 425 & 25 & 44 & & $\mathrm{TL}$ & -11.5041 & 32.9 & 764.2 & -11.3785 & 67.55 & 1008.9 \\
\hline 1100 Can Baseline & 426 & 25 & 43 & & $\mathrm{TL}$ & -10.9708 & 39.78 & 776.1 & -10.6855 & 77.25 & 1008.4 \\
\hline
\end{tabular}




\begin{tabular}{|c|c|c|c|c|c|c|c|c|c|c|c|}
\hline Type & $\begin{array}{l}\text { Frit } \\
\text { ID }\end{array}$ & $\begin{array}{l}\text { Min } \\
\text { WL }\end{array}$ & $\begin{array}{l}\text { Max } \\
\text { WL } \\
\end{array}$ & $\begin{array}{c}\text { Limited } \\
\text { Below By }\end{array}$ & $\begin{array}{c}\text { Limited } \\
\text { Above By }\end{array}$ & $\begin{array}{c}\begin{array}{c}\text { Del Gp } \\
\text { (min) }\end{array} \\
\end{array}$ & $\begin{array}{c}\text { Visc } \\
\text { (min) }\end{array}$ & $\begin{array}{c}\text { TL } \\
\text { (min) }\end{array}$ & $\begin{array}{c}\text { Del Gp } \\
\text { (max) }\end{array}$ & Visc (max) & TL $(\max )$ \\
\hline 1100 Can Baseline & 431 & 27 & 41 & Del Gp & lvisc & -13.4153 & 24.36 & 762.1 & -13.1197 & 41.56 & 946.9 \\
\hline 1100 Can Baseline & 441 & . & . & & & . & . & . & . & . & . \\
\hline 1100 Can 2nd Transfer, Baseline & 320 & 25 & 44 & & TL & -12.5731 & 28.43 & 752.7 & -12.202 & 54.48 & 1000.9 \\
\hline 1100 Can 2nd Transfer, Baseline & 417 & 25 & 43 & & TL & -11.8801 & 34.42 & 763.7 & -11.6948 & 62.71 & 999.6 \\
\hline 1100 Can 2nd Transfer, Baseline & 418 & 25 & 40 & & TL & -10.0625 & 58.93 & 799.2 & -9.8011 & 93.6 & 997.4 \\
\hline 1100 Can 2nd Transfer, Baseline & 425 & 25 & 42 & & TL & -11.1871 & 41.41 & 775.1 & -11.1692 & 71.92 & 998.6 \\
\hline 1100 Can 2nd Transfer, Baseline & 426 & 25 & 41 & & $\mathrm{TL}$ & -10.6251 & 49.54 & 786.9 & -10.4941 & 82.19 & 997.8 \\
\hline 1100 Can 2nd Transfer, Baseline & 431 & 25 & 43 & & lvisc & -13.266 & 25.56 & 742 & -12.7482 & 47.14 & 980.9 \\
\hline 1100 Can 2nd Transfer, Baseline & 441 & . & . & & & . & . & . & . & . & . \\
\hline 1100 Can Min Al, Na; Max Ce, Fe, Mn, U & 320 & 25 & 41 & & lvisc & -12.9716 & 24.82 & 746.8 & -12.9142 & 47.91 & 971.7 \\
\hline 1100 Can Min Al, Na; Max Ce, Fe, Mn, U & 417 & 25 & 43 & & TL & -12.3803 & 25.94 & 758.4 & -12.2786 & 55.24 & 1005.9 \\
\hline 1100 Can Min Al, Na; Max Ce, Fe, Mn, U & 418 & 25 & 40 & & TL & -10.7002 & 46.32 & 795.8 & -10.1996 & 82.86 & 1004.5 \\
\hline 1100 Can Min Al, Na; Max Ce, Fe, Mn, U & 425 & 25 & 42 & & TL & -11.8388 & 31.68 & 770.4 & -11.5856 & 63.47 & 1005.1 \\
\hline 1100 Can Min Al, Na; Max Ce, Fe, Mn, U & 426 & 25 & 41 & & TL & -11.2787 & 38.42 & 782.9 & -10.8926 & 72.64 & 1004.6 \\
\hline 1100 Can Min Al, Na; Max Ce, Fe, Mn, U & 431 & . & . & & & . & . & . & . & . & . \\
\hline 1100 Can Min Al, Na; Max Ce, Fe, Mn, U & 441 & . & . & & & . & . & . & . & . & . \\
\hline 1100 Can Max Al, Na; Min Mn, Ni, U & 320 & 25 & 53 & & lvisc & -12.2079 & 25.61 & 715.3 & -11.252 & 60.89 & 991.3 \\
\hline 1100 Can Max Al, Na; Min Mn, Ni, U & 417 & 25 & 54 & & $\mathrm{TL}$ & -11.5149 & 28.23 & 724.7 & -10.7928 & 69.96 & 1003.9 \\
\hline 1100 Can Max Al, Na; Min Mn, Ni, U & 418 & 27 & 51 & hvisc & $\mathrm{TL}$ & -9.5093 & 49.05 & 781.3 & -9.4415 & 99.81 & 1002.5 \\
\hline 1100 Can Max Al, Na; Min Mn, Ni, U & 425 & 25 & 53 & & $\mathrm{TL}$ & -10.8219 & 34.14 & 734.4 & -10.3834 & 80.09 & 1003.2 \\
\hline 1100 Can Max Al, Na; Min Mn, Ni, U & 426 & 25 & 52 & & TL & -10.1289 & 41.04 & 744.4 & -9.9556 & 91.36 & 1002.7 \\
\hline 1100 Can Max Al, Na; Min Mn, Ni, U & 431 & 25 & 50 & & lvisc & -12.9008 & 25.27 & 706.1 & -11.8164 & 52.79 & 963.7 \\
\hline 1100 Can Max Al, Na; Min Mn, Ni, U & 441 & 40 & 42 & Del Gp & lvisc & -13.359 & 25.14 & 864.4 & -13.2352 & 26.81 & 883.4 \\
\hline 1100 Can Min Ce, Mg, Ti & 320 & 25 & 41 & & $\mathrm{TL}$ & -12.4479 & 35.59 & 770.9 & -12.0553 & 57.1 & 993.3 \\
\hline 1100 Can Min Ce, Mg, Ti & 417 & 25 & 41 & & $\mathrm{TL}$ & -11.7549 & 41.14 & 782.2 & -11.5101 & 65.7 & 1003.3 \\
\hline 1100 Can Min Ce, Mg, Ti & 418 & 25 & 38 & & $\mathrm{TL}$ & -9.8374 & 68.85 & 818.6 & -9.6759 & 97.92 & 1000.3 \\
\hline 1100 Can Min Ce, Mg, Ti & 425 & 25 & 40 & & TL & -11.0619 & 49.11 & 793.9 & -10.971 & 75.31 & 1002 \\
\hline 1100 Can Min Ce, Mg, Ti & 426 & 25 & 39 & & TL & -10.4134 & 58.3 & 806 & -10.3689 & 86.02 & 1001 \\
\hline 1100 Can Min Ce, Mg, Ti & 431 & 25 & 42 & & $\mathrm{TL}$ & -13.1409 & 29.52 & 760 & -12.5666 & 49.43 & 995.2 \\
\hline 1100 Can Min Ce, Mg, Ti & 441 & . & . & & & . & . & . & . & . & . \\
\hline
\end{tabular}




\begin{tabular}{|c|c|c|c|c|c|c|c|c|c|c|c|}
\hline Type & $\begin{array}{l}\text { Frit } \\
\text { ID }\end{array}$ & $\begin{array}{l}\text { Min } \\
\text { WL }\end{array}$ & $\begin{array}{l}\text { Max } \\
\text { WL }\end{array}$ & $\begin{array}{c}\text { Limited } \\
\text { Below By }\end{array}$ & $\begin{array}{c}\text { Limited } \\
\text { Above By }\end{array}$ & $\begin{array}{c}\text { Del Gp } \\
\text { (min) }\end{array}$ & $\begin{array}{c}\text { Visc } \\
\text { (min) }\end{array}$ & $\begin{array}{c}\text { TL } \\
(\mathrm{min})\end{array}$ & $\begin{array}{c}\text { Del Gp } \\
\text { (max) }\end{array}$ & Visc (max) & TL (max) \\
\hline 1100 Can Min Fe & 320 & 25 & 45 & & $\mathrm{TL}$ & -12.3563 & 32.67 & 753.2 & -11.7924 & 58.8 & 1002.1 \\
\hline 1100 Can Min Fe & 417 & 25 & 44 & & $\overline{T L}$ & -11.6634 & 39.25 & 763.8 & -11.3031 & 67.62 & 1000.8 \\
\hline 1100 Can Min Fe & 418 & 26 & 41 & hvisc & $\mathrm{TL}$ & -9.7246 & 65.82 & 813.2 & -9.5931 & 98.49 & 998.6 \\
\hline 1100 Can Min Fe & 425 & 25 & 43 & & $\mathrm{TL}$ & -10.9704 & 46.88 & 774.8 & -10.7954 & 77.47 & 999.8 \\
\hline 1100 Can Min Fe & 426 & 25 & 42 & & TL & -10.2774 & 55.7 & 786.1 & -10.2692 & 88.44 & 999 \\
\hline 1100 Can Min Fe & 431 & 25 & 46 & & TL & -13.0493 & 27.03 & 742.8 & -12.2631 & 50.94 & 1003.6 \\
\hline 1100 Can Min Fe & 441 & . & . & & & . & . & . & . & . & . \\
\hline 1100 Can Max Mg & 320 & 25 & 43 & & lvisc & -12.8438 & 24.59 & 742 & -12.6872 & 50.02 & 982 \\
\hline 1100 Can Max Mg & 417 & 25 & 44 & & $\mathrm{TL}$ & -12.161 & 27.12 & 753.2 & -12.1508 & 57.64 & 1002.8 \\
\hline 1100 Can Max Mg & 418 & 25 & 41 & & TL & -10.524 & 48 & 789.2 & -10.0718 & 86.29 & 1001.2 \\
\hline 1100 Can Max Mg & 425 & 25 & 43 & & TL & -11.6338 & 33.01 & 764.8 & -11.4578 & 66.18 & 1001.9 \\
\hline 1100 Can Max Mg & 426 & 25 & 42 & & TL & -11.0881 & 39.93 & 776.8 & -10.7648 & 75.7 & 1001.4 \\
\hline 1100 Can Max Mg & 431 & 32 & 40 & Del Gp & lvisc & -13.4112 & 24.45 & 835.2 & -13.2677 & 34.13 & 937.7 \\
\hline 1100 Can Max Mg & 441 & . & . & & & . & . & . & . & . & . \\
\hline 1100 Can Max Ni & 320 & 25 & 40 & & TL & -12.7227 & 30.97 & 774.9 & -12.5195 & 52.27 & 997.3 \\
\hline 1100 Can Max Ni & 417 & 25 & 39 & & $\overline{T L}$ & -12.0297 & 37.42 & 786.9 & -11.9694 & 60.21 & 995.6 \\
\hline 1100 Can Max Ni & 418 & 25 & 36 & & $\overline{T L}$ & -10.2083 & 63.73 & 825.4 & -9.9507 & 90.06 & 992.2 \\
\hline 1100 Can Max Ni & 425 & 25 & 38 & & $\overline{T L}$ & -11.4009 & 44.94 & 799.3 & -11.3367 & 69.11 & 994.2 \\
\hline 1100 Can Max Ni & 426 & 25 & 37 & & $\mathrm{TL}$ & -10.8138 & 53.67 & 812.1 & -10.6437 & 79.03 & 993 \\
\hline 1100 Can Max Ni & 431 & 25 & 41 & & TL lvisc & -13.4157 & 25.47 & 763.4 & -13.0511 & 45.19 & 999.4 \\
\hline 1100 Can Max Ni & 441 & . & . & & & . & . & . & . & . & . \\
\hline 1100 Can Max Ti & 320 & 25 & 49 & & lvisc & -12.4189 & 25.2 & 715.4 & -11.8022 & 56.83 & 973.1 \\
\hline 1100 Can Max Ti & 417 & 25 & 52 & & lvisc & -11.7259 & 25.05 & 725.1 & -11.2816 & 65.36 & 1003 \\
\hline 1100 Can Max Ti & 418 & 25 & 50 & & $\mathrm{TL}$ & -9.9286 & 42.27 & 756.3 & -9.647 & 97.3 & 1009 \\
\hline 1100 Can Max Ti & 425 & 25 & 52 & & $\mathrm{TL}$ & -11.0329 & 28.94 & 735.2 & -10.8381 & 74.9 & 1009.6 \\
\hline 1100 Can Max Ti & 426 & 25 & 51 & & $\mathrm{TL}$ & -10.3926 & 35.09 & 745.6 & -10.34 & 85.51 & 1009.2 \\
\hline 1100 Can Max Ti & 431 & 25 & 46 & & lvisc & -13.1119 & 24.9 & 705.9 & -12.3783 & 49.22 & 941 \\
\hline 1100 Can Max Ti & 441 & . & . & & & . & . & . & . & . & . \\
\hline 1200 Can Baseline & 320 & 25 & 45 & & TL lvisc & -12.6418 & 25.73 & 748.7 & -12.3063 & 53.27 & 1007.5 \\
\hline 1200 Can Baseline & 417 & 25 & 44 & & TL & -11.9489 & 31.29 & 759.8 & -11.8056 & 61.34 & 1006.3 \\
\hline
\end{tabular}




\begin{tabular}{|c|c|c|c|c|c|c|c|c|c|c|c|}
\hline Type & $\begin{array}{l}\text { Frit } \\
\text { ID }\end{array}$ & $\begin{array}{l}\text { Min } \\
\text { WL }\end{array}$ & $\begin{array}{l}\text { Max } \\
\text { WL }\end{array}$ & $\begin{array}{c}\text { Limited } \\
\text { Below By }\end{array}$ & $\begin{array}{c}\text { Limited } \\
\text { Above By }\end{array}$ & $\begin{array}{c}\begin{array}{c}\text { Del Gp } \\
\text { (min) }\end{array} \\
\text { (m) }\end{array}$ & $\begin{array}{c}\text { Visc } \\
\text { (min) }\end{array}$ & $\begin{array}{c}\text { TL } \\
\text { (min) }\end{array}$ & $\begin{array}{c}\text { Del Gp } \\
(\max )\end{array}$ & Visc (max) & TL (max) \\
\hline 1200 Can Baseline & 418 & 25 & 41 & & $\mathrm{TL}$ & -10.1928 & 54.26 & 795.3 & -9.8699 & 91.61 & 1004.4 \\
\hline 1200 Can Baseline & 425 & 25 & 43 & & $\overline{T L}$ & -11.2865 & 37.82 & 771.2 & -11.2559 & 70.36 & 1005.4 \\
\hline 1200 Can Baseline & 426 & 25 & 42 & & TL & -10.7489 & 45.43 & 783 & -10.5629 & 80.43 & 1004.7 \\
\hline 1200 Can Baseline & 431 & 25 & 42 & & lvisc & -13.3348 & 25.43 & 738.1 & -12.8925 & 46.08 & 965.7 \\
\hline 1200 Can Baseline & 441 & . & . & & & . & . & . & . & . & . \\
\hline 1200 Can 2nd Transfer, Baseline & 320 & 25 & 44 & & $\mathrm{TL}$ & -12.5407 & 29.18 & 754.4 & -12.1451 & 55.1 & 1002.5 \\
\hline 1200 Can 2nd Transfer, Baseline & 417 & 25 & 43 & & $\mathrm{TL}$ & -11.8478 & 35.28 & 765.4 & -11.6393 & 63.42 & 1001.2 \\
\hline 1200 Can 2nd Transfer, Baseline & 418 & 25 & 40 & & $\mathrm{TL}$ & -10.0108 & 60.2 & 800.8 & -9.7688 & 94.61 & 998.9 \\
\hline 1200 Can 2nd Transfer, Baseline & 425 & 25 & 42 & & $\mathrm{TL}$ & -11.1548 & 42.4 & 776.8 & -11.1149 & 72.72 & 1000.1 \\
\hline 1200 Can 2nd Transfer, Baseline & 426 & 25 & 41 & & $\overline{T L}$ & -10.5721 & 50.67 & 788.6 & -10.4618 & 83.09 & 999.4 \\
\hline 1200 Can 2nd Transfer, Baseline & 431 & 25 & 44 & & lvisc & -13.2337 & 25.09 & 743.7 & -12.6625 & 47.68 & 993.4 \\
\hline 1200 Can 2nd Transfer, Baseline & 441 & . & . & & & . & . & . & . & . & . \\
\hline 1200 Can Min Al, Na; Max Ce, Fe, Mn, U & 320 & 25 & 42 & & TL lvisc & -12.8827 & 25.2 & 756.8 & -12.7612 & 49.45 & 997.7 \\
\hline 1200 Can Min Al, Na; Max Ce, Fe, Mn, U & 417 & 25 & 41 & & TL & -12.2232 & 30.73 & 768.6 & -12.1897 & 57.01 & 996.3 \\
\hline 1200 Can Min Al, Na; Max Ce, Fe, Mn, U & 418 & 25 & 39 & & $\overline{T L}$ & -10.5281 & 51.42 & 806.4 & -10.1107 & 85.42 & 1006.4 \\
\hline 1200 Can Min Al, Na; Max Ce, Fe, Mn, U & 425 & 25 & 40 & & $\overline{T L}$ & -11.6667 & 37.24 & 780.7 & -11.4967 & 65.47 & 995.2 \\
\hline 1200 Can Min Al, Na; Max Ce, Fe, Mn, U & 426 & 25 & 40 & & $\overline{T L}$ & -11.1123 & 42.87 & 793.3 & -10.8037 & 74.91 & 1006.7 \\
\hline 1200 Can Min Al, Na; Max Ce, Fe, Mn, U & 431 & 35 & 39 & Del Gp & lvisc & -13.4118 & 25.02 & 896.7 & -13.3463 & 29.81 & 949.8 \\
\hline 1200 Can Min Al, Na; Max Ce, Fe, Mn, U & 441 & . & . & & & . & . & . & . & . & . \\
\hline 1200 Can Max Al, Na; Min Fe, Mn, Ni, U & 320 & 25 & 56 & & TL lvisc & -12.0878 & 25.44 & 714.8 & -10.8808 & 63.34 & 1002.8 \\
\hline 1200 Can Max Al, Na; Min Fe, Mn, Ni, U & 417 & 25 & 55 & & TL & -11.3949 & 30.82 & 724 & -10.5039 & 72.74 & 1001.9 \\
\hline 1200 Can Max Al, Na; Min Fe, Mn, Ni, U & 418 & 29 & 53 & hvisc & TL & -9.308 & 50.72 & 803.9 & -9.2605 & 100.19 & 1006.5 \\
\hline 1200 Can Max Al, Na; Min Fe, Mn, Ni, U & 425 & 25 & 54 & & TL & -10.7019 & 37.1 & 733.5 & -10.1086 & 83.23 & 1001.2 \\
\hline 1200 Can Max Al, Na; Min Fe, Mn, Ni, U & 426 & 25 & 54 & & $\overline{\mathrm{TL}}$ & -10.0089 & 42.54 & 743.3 & -9.6835 & 94.89 & 1006.8 \\
\hline 1200 Can Max Al, Na; Min Fe, Mn, Ni, U & 431 & 25 & 53 & & lvisc & -12.7808 & 25.15 & 705.8 & -11.4318 & 54.94 & 978.1 \\
\hline 1200 Can Max Al, Na; Min Fe, Mn, Ni, U & 441 & 37 & 45 & Del Gp & lvisc & -13.3669 & 25.01 & 831.6 & -12.8337 & 31.5 & 905.6 \\
\hline 1200 Can Max Ni & 320 & 25 & 40 & & TL & -12.7206 & 31.04 & 775.1 & -12.5162 & 52.32 & 997.6 \\
\hline 1200 Can Max Ni & 417 & 25 & 39 & & $\mathrm{TL}$ & -12.0276 & 37.5 & 787 & -11.9662 & 60.28 & 995.8 \\
\hline 1200 Can Max Ni & 418 & 25 & 36 & & $\overline{T L}$ & -10.2053 & 63.84 & 825.6 & -9.9487 & 90.16 & 992.4 \\
\hline 1200 Can Max Ni & 425 & 25 & 38 & & TL & -11.3977 & 45.03 & 799.4 & -11.3346 & 69.19 & 994.4 \\
\hline
\end{tabular}


WSRC-TR-2005-00123

Revision 0

\begin{tabular}{|c|c|c|c|c|c|c|c|c|c|c|c|}
\hline Type & $\begin{array}{l}\text { Frit } \\
\text { ID }\end{array}$ & $\begin{array}{l}\text { Min } \\
\text { WL }\end{array}$ & $\begin{array}{l}\text { Max } \\
\text { WL }\end{array}$ & $\begin{array}{c}\text { Limited } \\
\text { Below By }\end{array}$ & $\begin{array}{c}\text { Limited } \\
\text { Above By }\end{array}$ & $\begin{array}{c}\text { Del Gp } \\
\text { (min) }\end{array}$ & $\begin{array}{c}\text { Visc } \\
(\min )\end{array}$ & $\begin{array}{c}\text { TL } \\
\text { (min) }\end{array}$ & $\begin{array}{l}\text { Del Gp } \\
(\max )\end{array}$ & Visc (max) & TL (max) \\
\hline 1200 Can Max Ni & 426 & 25 & 37 & & $\mathrm{TL}$ & -10.8108 & 53.77 & 812.3 & -10.6417 & 79.12 & 993.2 \\
\hline 1200 Can Max Ni & 431 & 25 & 41 & & TL lvisc & -13.4136 & 25.53 & 763.5 & -13.0477 & 45.24 & 999.6 \\
\hline 1200 Can Max Ni & 441 & . & . & & & . & . & . & . & . & . \\
\hline 1200 Can Min Ce & 320 & 25 & 45 & & TL & -12.3425 & 33.08 & 753.6 & -11.7675 & 59.11 & 1002.3 \\
\hline 1200 Can Min Ce & 417 & 25 & 44 & & TL & -11.6495 & 39.71 & 764.2 & -11.2788 & 67.97 & 1001 \\
\hline 1200 Can Min Ce & 418 & 26 & 41 & hvisc & TL & -9.7019 & 66.48 & 813.6 & -9.5788 & 98.99 & 998.8 \\
\hline 1200 Can Min Ce & 425 & 25 & 43 & & $\mathrm{TL}$ & -10.9565 & 47.41 & 775.2 & -10.7717 & 77.86 & 1000 \\
\hline 1200 Can Min Ce & 426 & 25 & 42 & & $\mathrm{TL}$ & -10.2636 & 56.29 & 786.6 & -10.246 & 88.88 & 999.2 \\
\hline 1200 Can Min Ce & 431 & 25 & 46 & & $\mathrm{TL}$ & -13.0355 & 27.38 & 743.3 & -12.2377 & 51.2 & 1003.8 \\
\hline 1200 Can Min Ce & 441 & . & . & & & . & . & . & . & . & . \\
\hline 1200 Can Min Mg, Ti & 320 & 25 & 42 & & TL & -12.4624 & 33.93 & 769.9 & -12.0552 & 56.83 & 1003.7 \\
\hline 1200 Can Min Mg, Ti & 417 & 25 & 41 & & $\mathrm{TL}$ & -11.7695 & 40.75 & 781.2 & -11.534 & 65.4 & 1002.2 \\
\hline 1200 Can Min Mg, Ti & 418 & 25 & 38 & & $\mathrm{TL}$ & -9.8596 & 68.29 & 817.6 & -9.6905 & 97.48 & 999.2 \\
\hline 1200 Can Min Mg, Ti & 425 & 25 & 40 & & $\mathrm{TL}$ & -11.0765 & 48.67 & 792.9 & -10.9944 & 74.97 & 1000.9 \\
\hline 1200 Can Min Mg, Ti & 426 & 25 & 39 & & TL & -10.4362 & 57.8 & 805 & -10.3835 & 85.63 & 999.9 \\
\hline 1200 Can Min Mg, Ti & 431 & 25 & 42 & & $\mathrm{TL}$ & -13.1554 & 29.22 & 759 & -12.5911 & 49.2 & 994.1 \\
\hline 1200 Can Min Mg, Ti & 441 & . & . & & & . & . & . & . & . & . \\
\hline 1200 Can Max Mg, Ti & 320 & 25 & 51 & & lvisc & -12.2967 & 25.75 & 715.3 & -11.5016 & 59.17 & 982.3 \\
\hline 1200 Can Max Mg, Ti & 417 & 25 & 54 & & TL lvisc & -11.6037 & 25.65 & 724.9 & -10.9848 & 68.02 & 1009.7 \\
\hline 1200 Can Max Mg, Ti & 418 & 26 & 51 & hvisc & TL & -9.6905 & 45.17 & 769.1 & -9.5311 & 98.98 & 1008.4 \\
\hline 1200 Can Max Mg, Ti & 425 & 25 & 53 & & TL & -10.9107 & 31.17 & 734.7 & -10.5718 & 77.89 & 1009 \\
\hline 1200 Can Max Mg, Ti & 426 & 25 & 52 & & TL & -10.2178 & 37.64 & 744.9 & -10.1404 & 88.89 & 1008.6 \\
\hline 1200 Can Max Mg, Ti & 431 & 25 & 48 & & lvisc & -12.9897 & 25.39 & 706 & -12.0738 & 51.28 & 952.5 \\
\hline 1200 Can Max Mg, Ti & 441 & . & . & & & . & . & . & . & . & . \\
\hline
\end{tabular}


WSRC-TR-2005-00123

Revision 0

\section{APPENDIX C}

Maximum Waste Loading as a Function of an Assumed PCCS $\mathrm{SO}_{4}$ Solubility Limit 
Table C.1. Maximum WLs as a Function of an Assumed $\mathrm{SO}_{4}$ Solubility Limit.

\begin{tabular}{|c|c|c|c|c|}
\hline & Sludge $\mathrm{SO}_{4}$ & $\begin{array}{c}\text { MAX } \\
\text { WL }\end{array}$ & $\begin{array}{c}\text { MAX } \\
\text { WL }\end{array}$ & $\begin{array}{c}\text { MAX } \\
\text { WL }\end{array}$ \\
\hline Type & (wt\%) & 0.4 & 0.5 & 0.6 \\
\hline SB4 Only Baseline & 1.098 & 36.4 & 45.5 & 54.6 \\
\hline SB4 Only Min Al, Na, Mg, Ti; Max Ce, Fe, Mg, Ni, U & 1.095 & 36.5 & 45.7 & 54.8 \\
\hline SB4 Only Max Al, Na, Mg, Ti; Min Ce, Fe, Mn, Ni, U & 1.109 & 36.1 & 45.1 & 54.1 \\
\hline 1100 Can Baseline & 1.099 & 36.4 & 45.5 & 54.6 \\
\hline 1100 Can 2nd Transfer, Baseline & 1.098 & 36.4 & 45.5 & 54.6 \\
\hline 1100 Can Min Al, Na; Max Ce, Fe, Mn, U & 1.097 & 36.5 & 45.6 & 54.7 \\
\hline 1100 Can Max Al, Na; Min Mn, Ni, U & 1.104 & 36.2 & 45.3 & 54.3 \\
\hline 1100 Can Min Ce, Mg, Ti & 1.097 & 36.5 & 45.6 & 54.7 \\
\hline 1100 Can Min Fe & 1.100 & 36.4 & 45.5 & 54.5 \\
\hline 1100 Can Max Mg & 1.099 & 36.4 & 45.5 & 54.6 \\
\hline 1100 Can Max Ni & 1.095 & 36.5 & 45.6 & 54.8 \\
\hline 1100 Can Max Ti & 1.103 & 36.3 & 45.3 & 54.4 \\
\hline 1200 Can Baseline & 1.098 & 36.4 & 45.5 & 54.6 \\
\hline 1200 Can 2nd Transfer, Baseline & 1.098 & 36.4 & 45.5 & 54.6 \\
\hline 1200 Can Min Al, Na; Max Ce, Fe, Mn, U & 1.096 & 36.5 & 45.6 & 54.7 \\
\hline 1200 Can Max Al, Na; Min Fe, Mn, Ni, U & 1.105 & 36.2 & 45.3 & 54.3 \\
\hline 1200 Can Max Ni & 1.095 & 36.5 & 45.6 & 54.8 \\
\hline 1200 Can Min Ce & 1.100 & 36.4 & 45.5 & 54.5 \\
\hline 1200 Can Min Mg, Ti & 1.097 & 36.5 & 45.6 & 54.7 \\
\hline 1200 Can Max Mg, Ti & 1.104 & 36.2 & 45.3 & 54.4 \\
\hline SB4 Baseline -App. A / ARP Stream + SRAT Product Solids & 1.131 & 35.4 & 44.2 & 53.0 \\
\hline SB4 Min Al, Na, Mg, Ti; Max Ce, Fe, Mg, Ni, U - App. A / ARP Stream + SRAT Product Solids & 1.128 & 35.5 & 44.3 & 53.2 \\
\hline SB4 Max Al, Na, Mg, Ti; Min Ce, Fe, Mn, Ni, U - App. A / ARP Stream + SRAT Product Solids & 1.142 & 35.0 & 43.8 & 52.5 \\
\hline SB4 1100 Can Baseline - App. A / ARP Stream + SRAT Product Solids & 1.131 & 35.4 & 44.2 & 53.0 \\
\hline SB4 1100 Can 2nd Transfer, Baseline - App.A / ARP Stream + SRAT Product Solids & 1.131 & 35.4 & 44.2 & 53.0 \\
\hline SB4 1100 Can Min Al, Na; Max Ce, Fe, Mn, U - App. A / ARP Stream + SRAT Product Solids & 1.130 & 35.4 & 44.3 & 53.1 \\
\hline
\end{tabular}




\begin{tabular}{|c|c|c|c|c|}
\hline & Sludge $\mathrm{SO}_{4}$ & $\begin{array}{l}\text { MAX } \\
\text { WL }\end{array}$ & $\begin{array}{c}\text { MAX } \\
\text { WL }\end{array}$ & $\begin{array}{c}\text { MAX } \\
\text { WL }\end{array}$ \\
\hline Type & (wt\%) & 0.4 & 0.5 & 0.6 \\
\hline SB4 1100 Can Max Al, Na; Min Mn, Ni, U - App. A / ARP Stream + SRAT Product Solids & 1.137 & 35.2 & 44.0 & 52.8 \\
\hline SB4 1100 Can Min Ce, Mg, Ti - App.A / ARP Stream + SRAT Product Solids & 1.130 & 35.4 & 44.2 & 53.1 \\
\hline SB4 1100 Can Min Fe - App.A / ARP Stream + SRAT Product Solids & 1.133 & 35.3 & 44.1 & 53.0 \\
\hline SB4 1100 Can Max Mg - App.A / ARP Stream + SRAT Product Solids & 1.131 & 35.4 & 44.2 & 53.0 \\
\hline SB4 1100 Can Max Ni - App.A / ARP Stream + SRAT Product Solids & 1.128 & 35.4 & 44.3 & 53.2 \\
\hline SB4 1100 Can Max Ti - App.A / ARP Stream + SRAT Product Solids & 1.136 & 35.2 & 44.0 & 52.8 \\
\hline SB4 1200 Can Baseline - App.A / ARP Stream + SRAT Product Solids & 1.131 & 35.4 & 44.2 & 53.0 \\
\hline SB4 1200 Can 2nd Transfer Baseline - App.A / ARP Stream + SRAT Product Solids & 1.131 & 35.4 & 44.2 & 53.0 \\
\hline SB4 1200 Can Min Al, Na; Max Ce, Fe, Mn, U - App.A / ARP Stream + SRAT Product Solids & 1.129 & 35.4 & 44.3 & 53.1 \\
\hline SB4 1200 Can Max Al, Na; Min Fe, Mn, Ni, U - App.A / ARP Stream + SRAT Product Solids & 1.138 & 35.2 & 44.0 & 52.7 \\
\hline SB4 1200 Can Max Ni - App.A / ARP Stream + SRAT Product Solids & 1.128 & 35.4 & 44.3 & 53.2 \\
\hline SB4 1200 Can Min Ce - App.A / ARP Stream + SRAT Product Solids & 1.133 & 35.3 & 44.1 & 53.0 \\
\hline SB4 1200 Can Min Mg, Ti - App.A / ARP Stream + SRAT Product Solids & 1.130 & 35.4 & 44.2 & 53.1 \\
\hline SB4 1200 Can Max Mg, Ti - App.A / ARP Stream + SRAT Product Solids & 1.137 & 35.2 & 44.0 & 52.8 \\
\hline SB4 Baseline -App. E / ARP Stream + SRAT Product Solids & 1.228 & 32.6 & 40.7 & 48.9 \\
\hline SB4 Min Al, Na, Mg, Ti; Max Ce, Fe, Mg, Ni, U - App. E / ARP Stream + SRAT Product Solids & 1.224 & 32.7 & 40.8 & 49.0 \\
\hline SB4 Max Al, Na, Mg, Ti; Min Ce, Fe, Mn, Ni, U - App. E / ARP Stream + SRAT Product Solids & 1.238 & 32.3 & 40.4 & 48.5 \\
\hline SB4 1100 Can Baseline - App. E / ARP Stream + SRAT Product Solids & 1.228 & 32.6 & 40.7 & 48.9 \\
\hline SB4 1100 Can 2nd Transfer, Baseline - App. E / ARP Stream + SRAT Product Solids & 1.228 & 32.6 & 40.7 & 48.9 \\
\hline SB4 1100 Can Min Al, Na; Max Ce, Fe, Mn, U - App. E / ARP Stream + SRAT Product Solids & 1.226 & 32.6 & 40.8 & 48.9 \\
\hline SB4 1100 Can Max Al, Na; Min Mn, Ni, U - App. E / ARP Stream + SRAT Product Solids & 1.233 & 32.4 & 40.5 & 48.7 \\
\hline SB4 1100 Can Min Ce, Mg, Ti - App. E / ARP Stream + SRAT Product Solids & 1.227 & 32.6 & 40.8 & 48.9 \\
\hline SB4 1100 Can Min Fe - App. E / ARP Stream + SRAT Product Solids & 1.229 & 32.5 & 40.7 & 48.8 \\
\hline SB4 1100 Can Max Mg - App. E / ARP Stream + SRAT Product Solids & 1.228 & 32.6 & 40.7 & 48.9 \\
\hline SB4 1100 Can Max Ni - App. E / ARP Stream + SRAT Product Solids & 1.225 & 32.7 & 40.8 & 49.0 \\
\hline SB4 1100 Can Max Ti - App. E / ARP Stream + SRAT Product Solids & 1.232 & 32.5 & 40.6 & 48.7 \\
\hline SB4 1200 Can Baseline - App. E / ARP Stream + SRAT Product Solids & 1.228 & 32.6 & 40.7 & 48.9 \\
\hline SB4 1200 Can 2nd Transfer Baseline - App. E / ARP Stream + SRAT Product Solids & 1.228 & 32.6 & 40.7 & 48.9 \\
\hline SB4 1200 Can Min Al, Na; Max Ce, Fe, Mn, U - App. E / ARP Stream + SRAT Product Solids & 1.226 & 32.6 & 40.8 & 48.9 \\
\hline
\end{tabular}




\begin{tabular}{|c|c|c|c|c|}
\hline & Sludge $\mathrm{SO}_{4}$ & $\begin{array}{l}\text { MAX } \\
\text { WL }\end{array}$ & $\begin{array}{c}\text { MAX } \\
\text { WL }\end{array}$ & $\begin{array}{c}\text { MAX } \\
\text { WL }\end{array}$ \\
\hline Type & (wt\%) & 0.4 & 0.5 & 0.6 \\
\hline SB4 1200 Can Max Al, Na; Min Fe, Mn, Ni, U - App. E / ARP Stream + SRAT Product Solids & 1.234 & 32.4 & 40.5 & 48.6 \\
\hline SB4 1200 Can Max Ni - App. E / ARP Stream + SRAT Product Solids & 1.225 & 32.7 & 40.8 & 49.0 \\
\hline SB4 1200 Can Min Ce - App. E / ARP Stream + SRAT Product Solids & 1.229 & 32.5 & 40.7 & 48.8 \\
\hline SB4 1200 Can Min Mg, Ti - App. E / ARP Stream + SRAT Product Solids & 1.227 & 32.6 & 40.8 & 48.9 \\
\hline SB4 1200 Can Max Mg, Ti - App. E / ARP Stream + SRAT Product Solids & 1.233 & 32.4 & 40.6 & 48.7 \\
\hline SB4 Baseline -App. K / ARP Stream + SRAT Product Solids & 1.264 & 31.7 & 39.6 & 47.5 \\
\hline SB4 Min Al, Na, Mg, Ti; Max Ce, Fe, Mg, Ni, U - App. K / ARP Stream + SRAT Product Solids & 1.260 & 31.7 & 39.7 & 47.6 \\
\hline SB4 Max Al, Na, Mg, Ti; Min Ce, Fe, Mn, Ni, U - App. K / ARP Stream + SRAT Product Solids & 1.274 & 31.4 & 39.3 & 47.1 \\
\hline SB4 1100 Can Baseline - App. K / ARP Stream + SRAT Product Solids & 1.264 & 31.7 & 39.6 & 47.5 \\
\hline SB4 1100 Can 2nd Transfer, Baseline - App. K / ARP Stream + SRAT Product Solids & 1.264 & 31.7 & 39.6 & 47.5 \\
\hline SB4 1100 Can Min Al, Na; Max Ce, Fe, Mn, U - App. K / ARP Stream + SRAT Product Solids & 1.262 & 31.7 & 39.6 & 47.5 \\
\hline SB4 1100 Can Max Al, Na; Min Mn, Ni, U - App. K / ARP Stream + SRAT Product Solids & 1.269 & 31.5 & 39.4 & 47.3 \\
\hline SB4 1100 Can Min Ce, Mg, Ti - App. K / ARP Stream + SRAT Product Solids & 1.263 & 31.7 & 39.6 & 47.5 \\
\hline SB4 1100 Can Min Fe - App. K / ARP Stream + SRAT Product Solids & 1.265 & 31.6 & 39.5 & 47.4 \\
\hline SB4 1100 Can Max Mg - App. K / ARP Stream + SRAT Product Solids & 1.264 & 31.7 & 39.6 & 47.5 \\
\hline SB4 1100 Can Max Ni - App. K / ARP Stream + SRAT Product Solids & 1.261 & 31.7 & 39.6 & 47.6 \\
\hline SB4 1100 Can Max Ti - App. K / ARP Stream + SRAT Product Solids & 1.268 & 31.5 & 39.4 & 47.3 \\
\hline SB4 1200 Can Baseline - App. K / ARP Stream + SRAT Product Solids & 1.264 & 31.7 & 39.6 & 47.5 \\
\hline SB4 1200 Can 2nd Transfer Baseline - App. K / ARP Stream + SRAT Product Solids & 1.264 & 31.7 & 39.6 & 47.5 \\
\hline SB4 1200 Can Min Al, Na; Max Ce, Fe, Mn, U - App. K / ARP Stream + SRAT Product Solids & 1.262 & 31.7 & 39.6 & 47.5 \\
\hline SB4 1200 Can Max Al, Na; Min Fe, Mn, Ni, U - App. K / ARP Stream + SRAT Product Solids & 1.269 & 31.5 & 39.4 & 47.3 \\
\hline SB4 1200 Can Max Ni - App. K / ARP Stream + SRAT Product Solids & 1.261 & 31.7 & 39.6 & 47.6 \\
\hline SB4 1200 Can Min Ce - App. K / ARP Stream + SRAT Product Solids & 1.265 & 31.6 & 39.5 & 47.4 \\
\hline SB4 1200 Can Min Mg, Ti - App. K / ARP Stream + SRAT Product Solids & 1.263 & 31.7 & 39.6 & 47.5 \\
\hline SB4 1200 Can Max Mg, Ti - App. K / ARP Stream + SRAT Product Solids & 1.269 & 31.5 & 39.4 & 47.3 \\
\hline SB4 Baseline -App. M / ARP Stream + SRAT Product Solids & 1.212 & 33.0 & 41.3 & 49.5 \\
\hline SB4 Min Al, Na, Mg, Ti; Max Ce, Fe, Mg, Ni, U - App. M / ARP Stream + SRAT Product Solids & 1.208 & 33.1 & 41.4 & 49.7 \\
\hline SB4 Max Al, Na, Mg, Ti; Min Ce, Fe, Mn, Ni, U - App. M / ARP Stream + SRAT Product Solids & 1.222 & 32.7 & 40.9 & 49.1 \\
\hline SB4 1100 Can Baseline - App. M / ARP Stream + SRAT Product Solids & 1.212 & 33.0 & 41.3 & 49.5 \\
\hline
\end{tabular}




\begin{tabular}{|c|c|c|c|c|}
\hline & Sludge $\mathrm{SO}_{4}$ & $\begin{array}{c}\text { MAX } \\
\text { WL }\end{array}$ & $\begin{array}{c}\text { MAX } \\
\text { WL }\end{array}$ & $\begin{array}{l}\text { MAX } \\
\text { WL }\end{array}$ \\
\hline Type & $(\mathrm{wt} \%)$ & 0.4 & 0.5 & 0.6 \\
\hline SB4 1100 Can 2nd Transfer, Baseline - App. M / ARP Stream + SRAT Product Solids & 1.211 & 33.0 & 41.3 & 49.5 \\
\hline SB4 1100 Can Min Al, Na; Max Ce, Fe, Mn, U - App. M / ARP Stream + SRAT Product Solids & 1.210 & 33.1 & 41.3 & 49.6 \\
\hline SB4 1100 Can Max Al, Na; Min Mn, Ni, U - App. M / ARP Stream + SRAT Product Solids & 1.217 & 32.9 & 41.1 & 49.3 \\
\hline SB4 1100 Can Min Ce, Mg, Ti - App. M / ARP Stream + SRAT Product Solids & 1.210 & 33.0 & 41.3 & 49.6 \\
\hline SB4 1100 Can Min Fe - App. M / ARP Stream + SRAT Product Solids & 1.213 & 33.0 & 41.2 & 49.5 \\
\hline SB4 1100 Can Max Mg - App. M / ARP Stream + SRAT Product Solids & 1.212 & 33.0 & 41.3 & 49.5 \\
\hline SB4 1100 Can Max Ni - App. M / ARP Stream + SRAT Product Solids & 1.209 & 33.1 & 41.4 & 49.6 \\
\hline SB4 1100 Can Max Ti - App. M / ARP Stream + SRAT Product Solids & 1.216 & 32.9 & 41.1 & 49.3 \\
\hline SB4 1200 Can Baseline - App. M / ARP Stream + SRAT Product Solids & 1.212 & 33.0 & 41.3 & 49.5 \\
\hline SB4 1200 Can 2nd Transfer Baseline - App. M / ARP Stream + SRAT Product Solids & 1.212 & 33.0 & 41.3 & 49.5 \\
\hline SB4 1200 Can Min Al, Na; Max Ce, Fe, Mn, U - App. M / ARP Stream + SRAT Product Solids & 1.210 & 33.1 & 41.3 & 49.6 \\
\hline SB4 1200 Can Max Al, Na; Min Fe, Mn, Ni, U - App. M / ARP Stream + SRAT Product Solids & 1.218 & 32.9 & 41.1 & 49.3 \\
\hline SB4 1200 Can Max Ni - App. M / ARP Stream + SRAT Product Solids & 1.209 & 33.1 & 41.4 & 49.6 \\
\hline SB4 1200 Can Min Ce - App. M / ARP Stream + SRAT Product Solids & 1.213 & 33.0 & 41.2 & 49.5 \\
\hline SB4 1200 Can Min Mg, Ti - App. M / ARP Stream + SRAT Product Solids & 1.211 & 33.0 & 41.3 & 49.6 \\
\hline SB4 1200 Can Max Mg, Ti - App. M / ARP Stream + SRAT Product Solids & 1.217 & 32.9 & 41.1 & 49.3 \\
\hline SB4 Baseline -App. V / ARP Stream + SRAT Product Solids & 1.223 & 32.7 & 40.9 & 49.0 \\
\hline SB4 Min Al, Na, Mg, Ti; Max Ce, Fe, Mg, Ni, U - App. V / ARP Stream + SRAT Product Solids & 1.220 & 32.8 & 41.0 & 49.2 \\
\hline SB4 Max Al, Na, Mg, Ti; Min Ce, Fe, Mn, Ni, U - App. V / ARP Stream + SRAT Product Solids & 1.233 & 32.4 & 40.5 & 48.6 \\
\hline SB4 1100 Can Baseline - App. V / ARP Stream + SRAT Product Solids & 1.223 & 32.7 & 40.9 & 49.0 \\
\hline SB4 1100 Can 2nd Transfer, Baseline - App. V / ARP Stream + SRAT Product Solids & 1.223 & 32.7 & 40.9 & 49.0 \\
\hline SB4 1100 Can Min Al, Na; Max Ce, Fe, Mn, U - App. V / ARP Stream + SRAT Product Solids & 1.222 & 32.7 & 40.9 & 49.1 \\
\hline SB4 1100 Can Max Al, Na; Min Mn, Ni, U - App. V / ARP Stream + SRAT Product Solids & 1.229 & 32.6 & 40.7 & 48.8 \\
\hline SB4 1100 Can Min Ce, Mg, Ti - App. V / ARP Stream + SRAT Product Solids & 1.222 & 32.7 & 40.9 & 49.1 \\
\hline SB4 1100 Can Min Fe - App. V / ARP Stream + SRAT Product Solids & 1.225 & 32.7 & 40.8 & 49.0 \\
\hline SB4 1100 Can Max Mg - App. V / ARP Stream + SRAT Product Solids & 1.223 & 32.7 & 40.9 & 49.0 \\
\hline SB4 1100 Can Max Ni - App. V / ARP Stream + SRAT Product Solids & 1.221 & 32.8 & 41.0 & 49.2 \\
\hline SB4 1100 Can Max Ti - App. V / ARP Stream + SRAT Product Solids & 1.228 & 32.6 & 40.7 & 48.9 \\
\hline SB4 1200 Can Baseline - App. V / ARP Stream + SRAT Product Solids & 1.223 & 32.7 & 40.9 & 49.0 \\
\hline
\end{tabular}




\begin{tabular}{|c|c|c|c|c|}
\hline & Sludge $\mathrm{SO}_{4}$ & $\begin{array}{c}\text { MAX } \\
\text { WL }\end{array}$ & $\begin{array}{c}\text { MAX } \\
\text { WL }\end{array}$ & $\begin{array}{c}\text { MAX } \\
\text { WL }\end{array}$ \\
\hline Type & (wt\%) & 0.4 & 0.5 & 0.6 \\
\hline SB4 1200 Can 2nd Transfer Baseline - App. V / ARP Stream + SRAT Product Solids & 1.223 & 32.7 & 40.9 & 49.0 \\
\hline SB4 1200 Can Min Al, Na; Max Ce, Fe, Mn, U - App. V / ARP Stream + SRAT Product Solids & 1.222 & 32.7 & 40.9 & 49.1 \\
\hline SB4 1200 Can Max Al, Na; Min Fe, Mn, Ni, U - App. V / ARP Stream + SRAT Product Solids & 1.229 & 32.5 & 40.7 & 48.8 \\
\hline SB4 1200 Can Max Ni - App. V/ ARP Stream + SRAT Product Solids & 1.221 & 32.8 & 41.0 & 49.2 \\
\hline SB4 1200 Can Min Ce - App. V / ARP Stream + SRAT Product Solids & 1.225 & 32.7 & 40.8 & 49.0 \\
\hline SB4 1200 Can Min Mg, Ti - App. V / ARP Stream + SRAT Product Solids & 1.222 & 32.7 & 40.9 & 49.1 \\
\hline SB4 1200 Can Max Mg, Ti - App. V / ARP Stream + SRAT Product Solids & 1.228 & 32.6 & 40.7 & 48.8 \\
\hline
\end{tabular}


WSRC-TR-2005-00123

Revision 0

\section{Distribution:}

E.W. Holtzscheiter, 773-A

J.E. Occhipinti, 704-S

D.A. Crowley, 999-W

S.L. Marra, 999-W

T.B. Calloway, 999-W

N.E. Bibler, 773-A

C.M. Jantzen, 773-A

J.R. Harbour, 773-42A

G.G. Wicks, 773-A

D.K. Peeler, 999-W

T.B. Edwards, 773-42A

C.C. Herman, 773-42A

R.M. Hoeppel, 704-27S

J.F. Iaukea, 704-30S

J.W. Ray, 704-S

F.A. Washburn, 704-27S

A.V. Staub, 704-27S

H.H. Elder, 766-H

D.C. Bumgardner, 766-H

W.B. Van Pelt, 704-S

H.B. Shah, 766-H

M.S. Miller, 704-S

E.W. Harrison, 766-H 